\title{
Phosphorylation-inducing Chimeric Small molecules
}

Sachini U. Siriwardena, ${ }^{1,2,5}$ Dhanushka N. P. Munkanatta Godage, ${ }^{1,2,5}$ Veronika M. Shoba, ${ }^{1,2,5}$ Sophia Lai, ${ }^{1,3,5}$ Mengchao Shi, ${ }^{1,2,4}$ Peng Wu, ${ }^{1,2,4}$ Santosh K. Chaudhary, ${ }^{1,2}$ Stuart L. Schreiber, ${ }^{1,3}$ and Amit Choudhary ${ }^{1,2,4 *}$

${ }^{1}$ Chemical Biology and Therapeutics Science, Broad Institute of MIT and Harvard, Cambridge, MA 02142, USA 2Department of Medicine, Harvard Medical School, Boston, MA 02115, USA

${ }^{3}$ Department of Chemistry and Chemical Biology, Harvard University, 12 Oxford Street, Cambridge, Massachusetts 02138, USA

${ }^{4}$ Divisions of Renal Medicine and Engineering, Brigham and Women's Hospital, Boston, MA 02115, USA

${ }^{5}$ These authors contributed equally to this work and listed arbitrarily.

*Correspondence: achoudhary@bwh.harvard.edu (A.C.)

*To whom correspondence should be addressed:

\section{Amit Choudhary}

Chemical Biology and Therapeutics Science

Broad Institute of MIT and Harvard

415 Main Street, Rm 3012

Cambridge, MA 02142

Phone: (617) 714-7445

Fax: (617) 715-8969

Email: achoudhary@bwh.harvard.edu 


\section{TABLE OF CONTENTS}

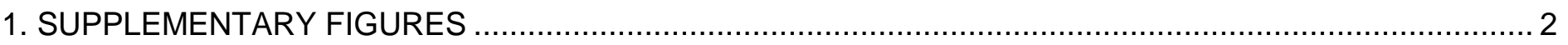

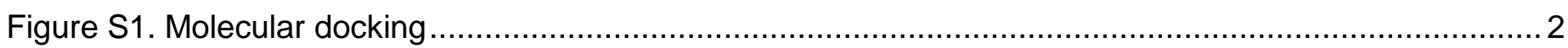

Figure S2. Biochemical validation of modified activators and PHICS intermediates by ADP Glo assay ..........2

Figure S3. Synthesis of AMPK activator, bifunctional molecules with different linkers and inactive analogue. 3

Figure S4. Synthesis of PKC activator, bifunctional molecules with different linkers and inactive analogue ...3

Figure S5. Identification of the optimal PHICS for BRD4 phosphorylation by AMPK ….............................. 4

Figure S6. Identification of the optimal PHICS for BRD4 phosphorylation by PKC .................................... 4

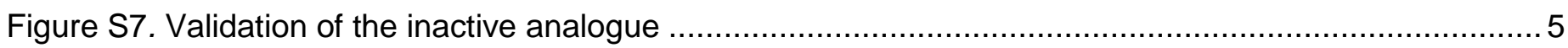

Figure S8. Bell-shaped dependence of BRD4 phosphorylation. ....................................................... 5

Figure S9. Mass spectrometry identification of BRD4 phosphorylation in the presence of PHICS1 .............. 8

Figure S10. Mass spectrometry identification of BRD4 phosphorylation in the presence of PHICS2 .............9

Figure S11. ADP-Glo assay for AMPK-mediated phosphorylation of different peptide sequences. .............. 10

Figure S12. ADP-Glo assay for the activation of different AMPK isoforms by PF-06409577 ..................... 10

Figure S13. AlphaScreen assay for the ternary complex formation with PHICS1 ...................................11

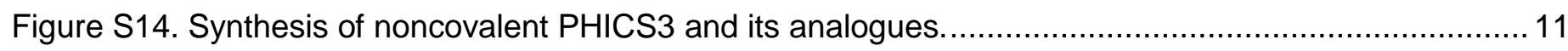

Figure S15. In-vitro biochemical validation of BTK phosphorylation in the presence of PHICS3.................. 12

Figure S16. Cell base studies for PHICS3 mediated BTK phosphorylation by AMPK ................................ 12

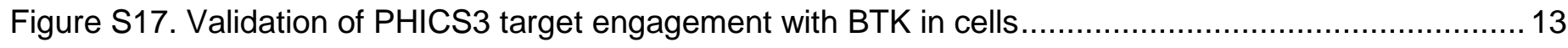

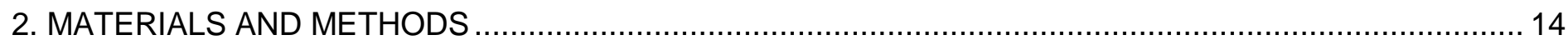

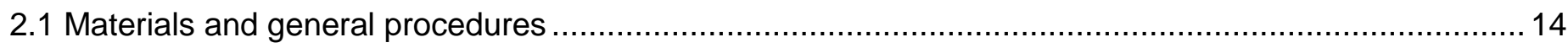

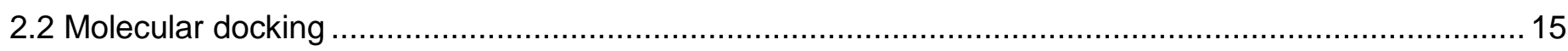

2.3 ADP-Glo kinase assay to validate the kinase activation by PHICS molecule ........................................ 15

2.4 ADP-Glo kinase assay to evaluate the catalytic nature between kinase and PHICS molecules.............. 16

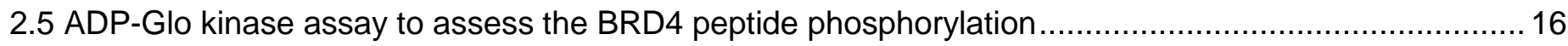

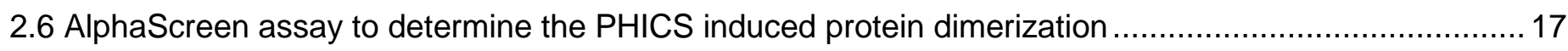

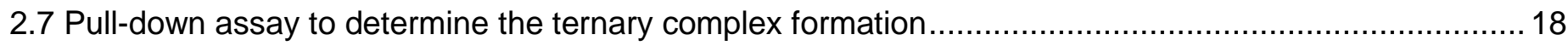

2.8 Immunoblotting analysis to confirm the BRD4 phosphorylation in vitro............................................. 18

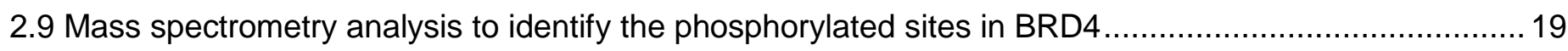

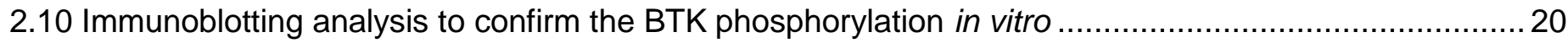

2.11 Validation of ternary complex (AMPK: PHICS3: BTK) formation in HEK293T cells................................ 20

2.12 Immunoblotting analysis to confirm the BTK phosphorylation in HEK293T cells ..................................21

2.13 Confirmation of the phosphorylation site and target engagement by mutational studies ......................... 22

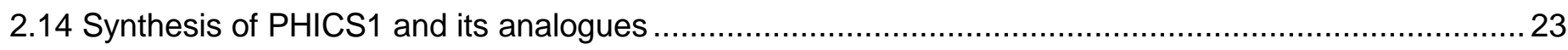

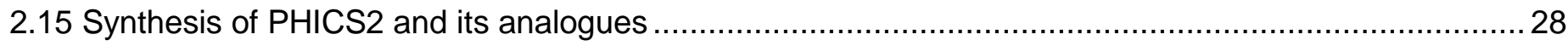

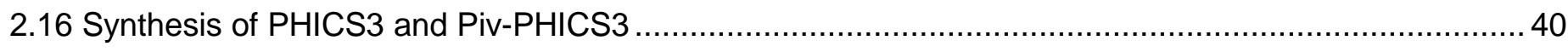

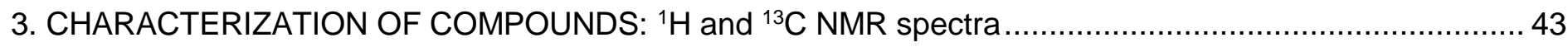

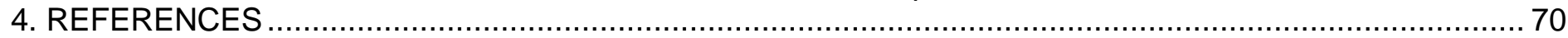




\section{Supplementary figures}

A

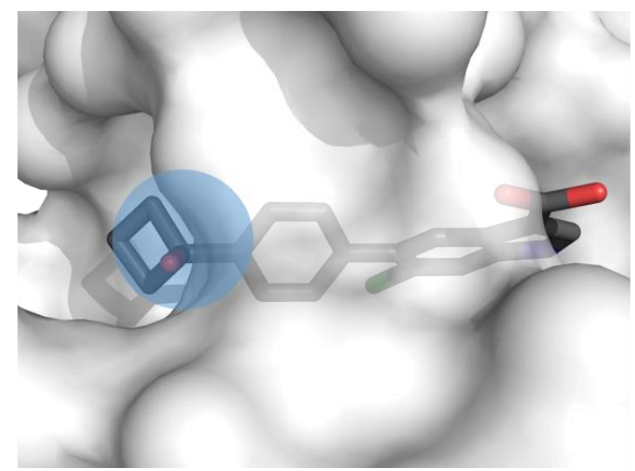

$\mathrm{B}$

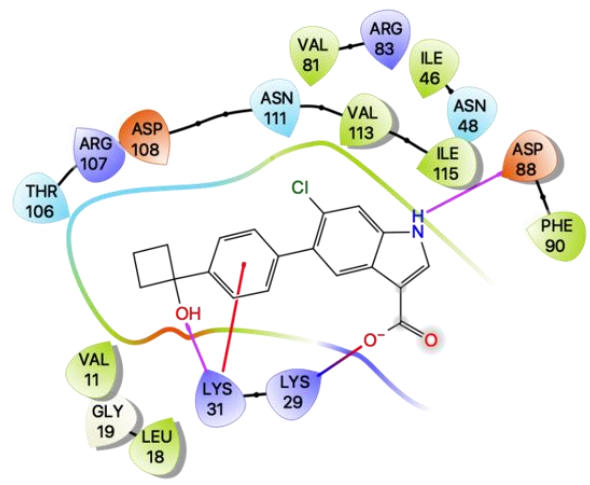

Figure S1. Molecular docking. (A) Co-crystal structure of activator PF-06409577 bound to AMPK (PDB ID: 5KQ5). The solvent-exposed site modified for linker attachment is highlighted in blue. (B) The 2-D ligand map showing key interactions of the molecule with Lys29, Lys31, and Asp88.<smiles>O=C(O)c1c[nH]c2cc(Cl)c(-c3ccc(C4(O)CCC4)cc3)cc12</smiles>

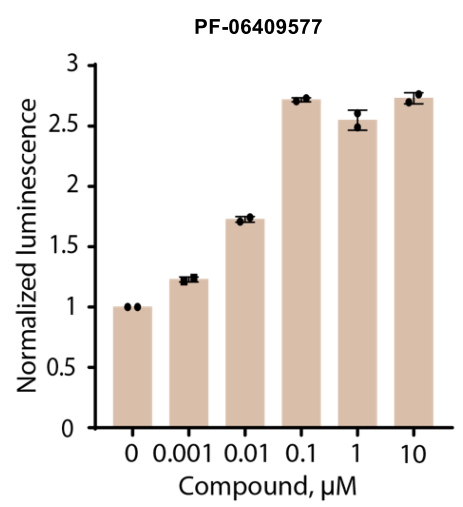<smiles>CC(=O)NCCOc1ccc(-c2cc3c(C(=O)O)c[nH]c3cc2Cl)cc1</smiles>

AMPK activator

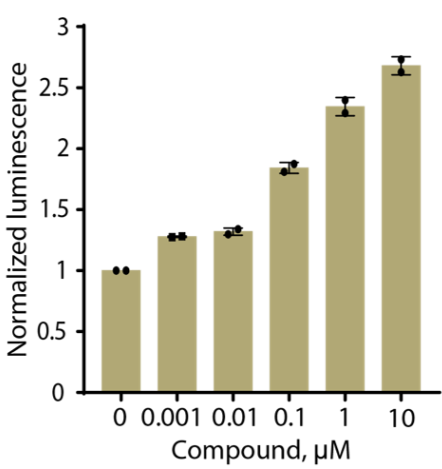<smiles>NS(=O)(=O)NCCOc1ccc(-c2cc3c(C(=O)O)c[nH]c3cc2Cl)cc1</smiles>

AMPK activator with linker

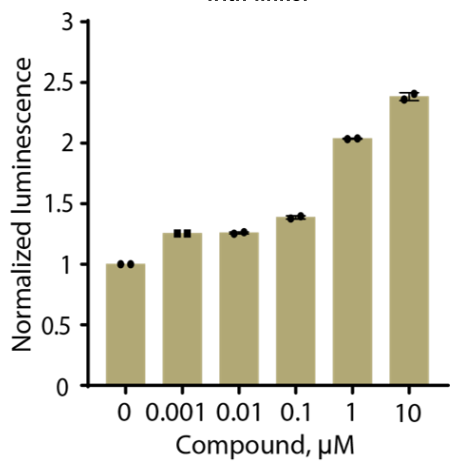

B

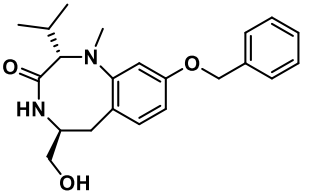

PKC activator

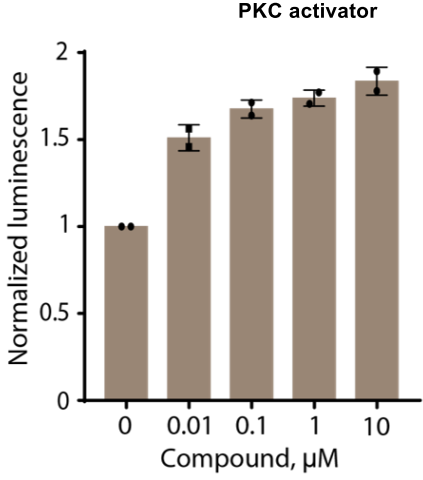

Figure S2. Biochemical validation of modified activators and PHICS intermediates by ADP Glo assay. (A) Biochemical validation of AMPK activation by potent activator PF-06409577, modified AMPK activator and AMPK activator with linker by ADP-Glo assay with SAMS peptide as the substrate. (B) ADP-Glo assay using CREBtide peptide as the substrate to determine PKCa activation by modified PKC activator. 


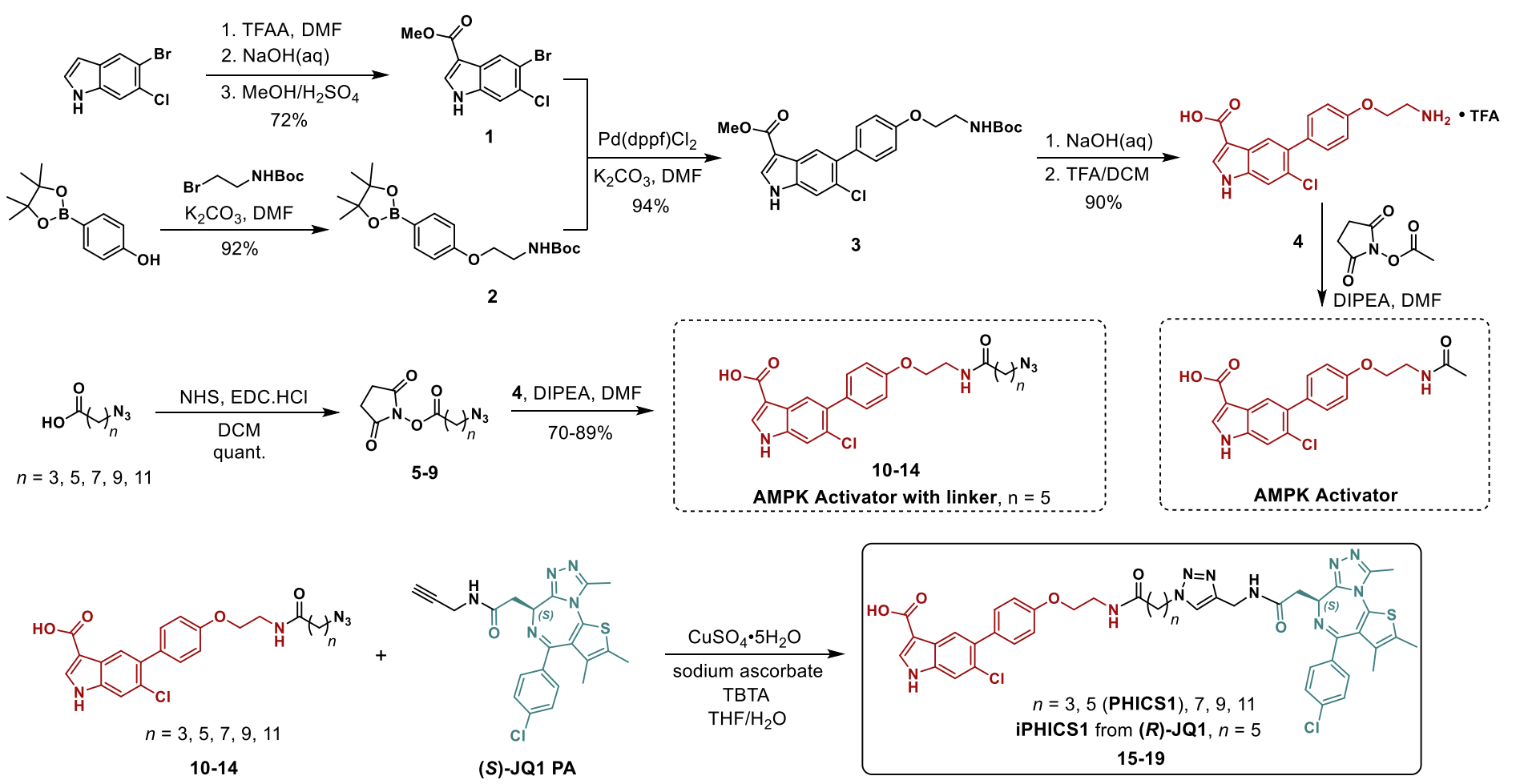

Figure S3. Synthesis of the AMPK activator, AMPK activator with linker, bifunctional AMPK-PHICS with different linker lengths (PHICS1, the lead compound derived from $n=5$ ), and the inactive analogue iPHICS1.

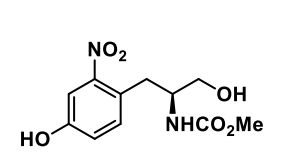

20

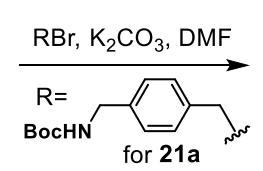

$\mathrm{R}=\mathrm{Bn}$ for $\mathbf{2 1 b}$
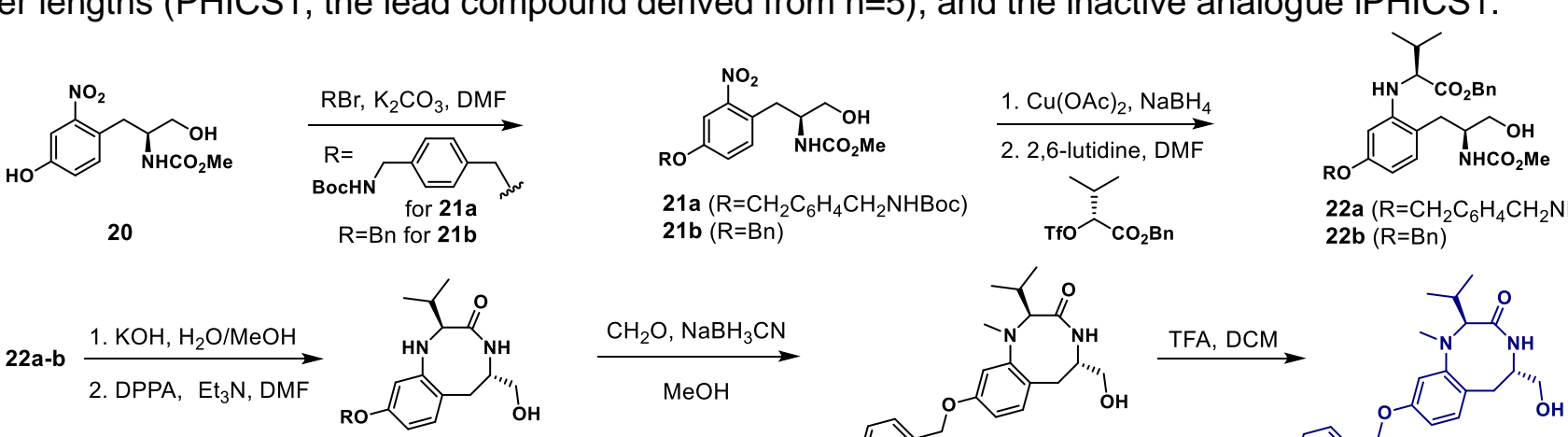

$23\left(\mathrm{R}=\mathrm{CH}_{2} \mathrm{C}_{6} \mathrm{H}_{4} \mathrm{CH}_{2} \mathrm{NHBoc}\right)$ PKC activator ( $\mathrm{R}=\mathrm{Bn})$
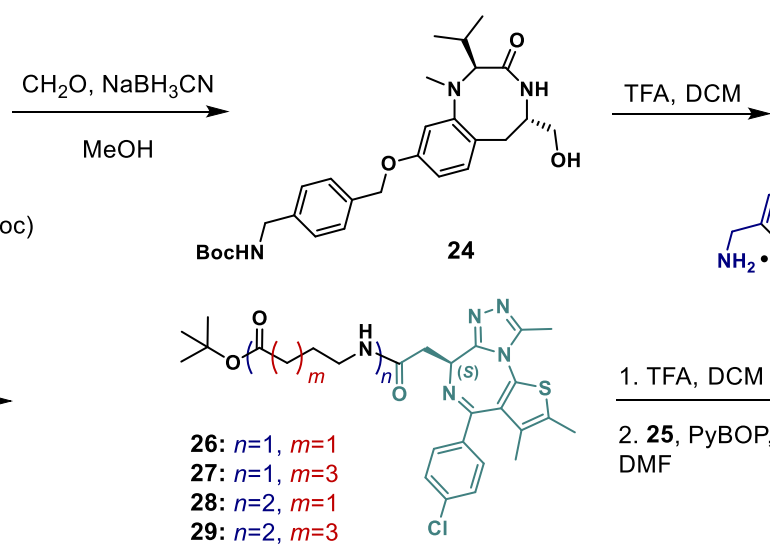

22b $(\mathrm{R}=\mathrm{Bn})$

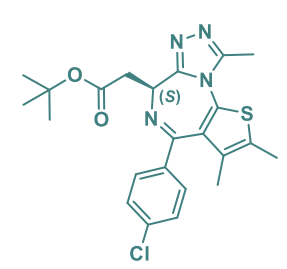

(S)-JQ1

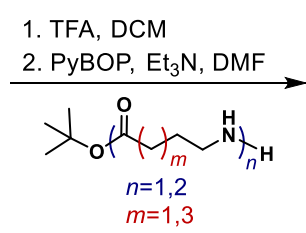

$m=1,3$

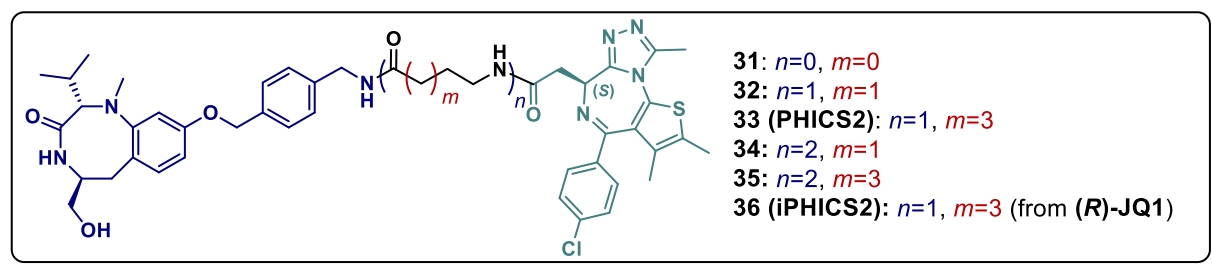

Figure S4. Synthesis of the PKC activator and bifunctional PKC-PHICS with different linker lengths (PHICS2, the lead compound derived from $n=1, m=3$ ), and the inactive analogue iPHICS2. 
A

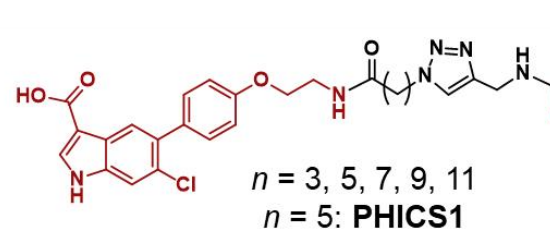

C

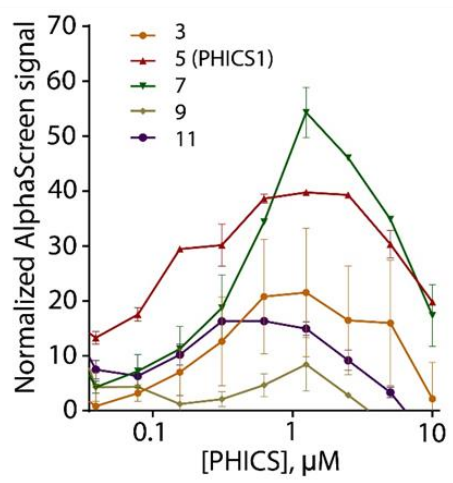

B
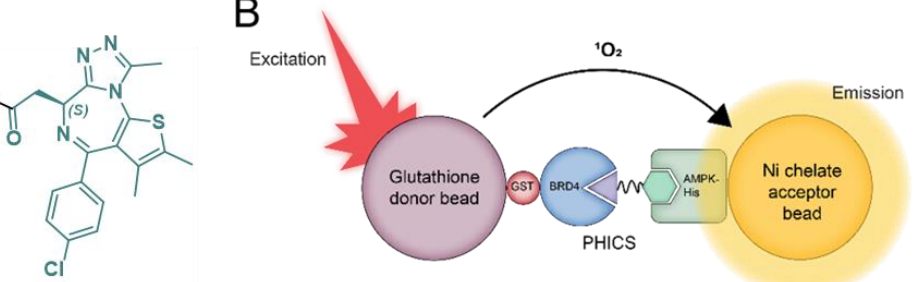

$\mathrm{D}$

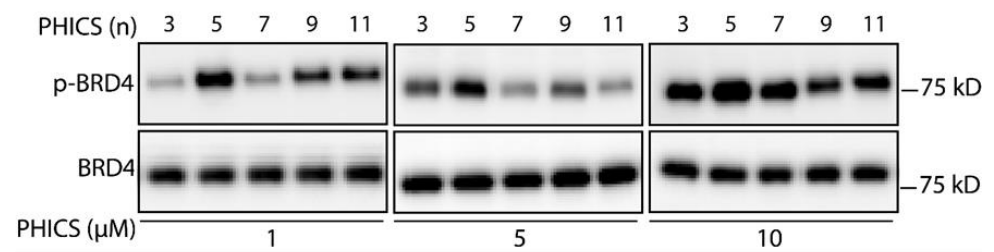

Figure S5. Identification of the optimal PHICS for BRD4 phosphorylation by AMPK. (A) Structures of AMPKPHICS analogues with varying linker length. (B) Schematic of AlphaScreen assay for BRD4-PHICS-AMPK ternary complex formation. (C) AlphaScreen assay for AMPK-PHICS with different linkers normalized to DMSO. (D) Western blot analysis of AMPK catalyzed BRD4 phosphorylation with different concentrations of AMPKPHICS analogues.

A

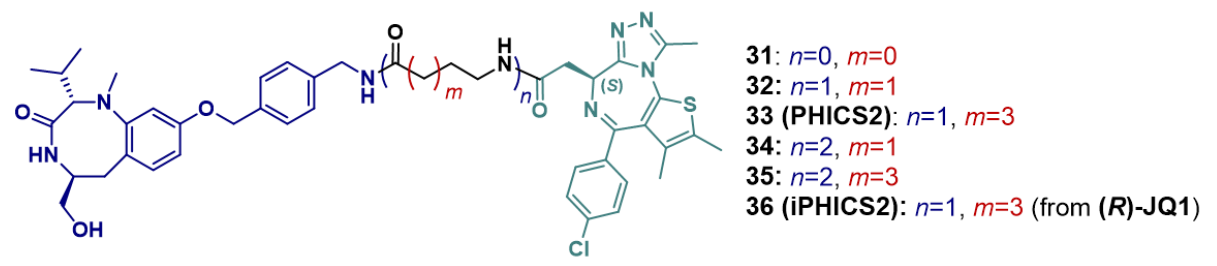

B

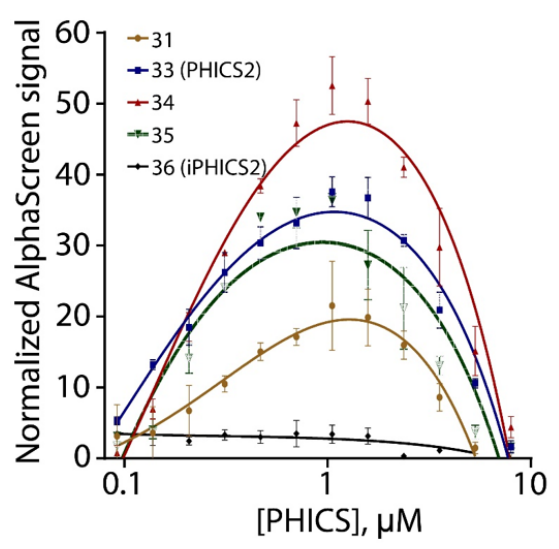

C

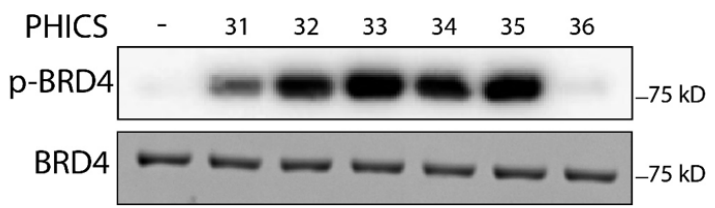

Figure S6. Identification of the optimal PHICS for BRD4 phosphorylation by PKC. (A) Structures of PKC-PHICS analogues with varying linker length. (B) AlphaScreen assay with different PKC-PHICS analogues for ternary complex formation normalized to DMSO. (C) Western blot analysis to compare BRD4 phosphorylation mediated by different PKC-PHICS molecules. 
A

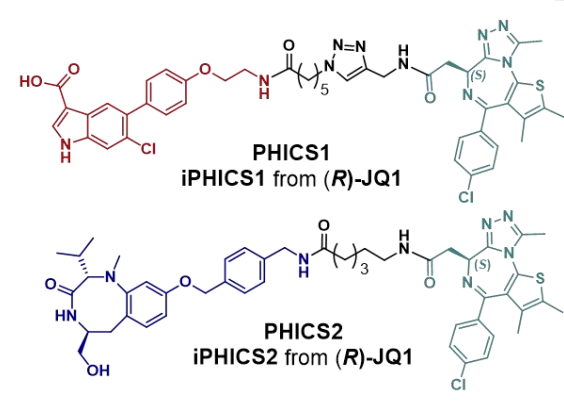

$\mathrm{E}$

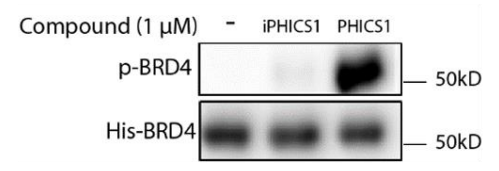

$\mathrm{F}$
B

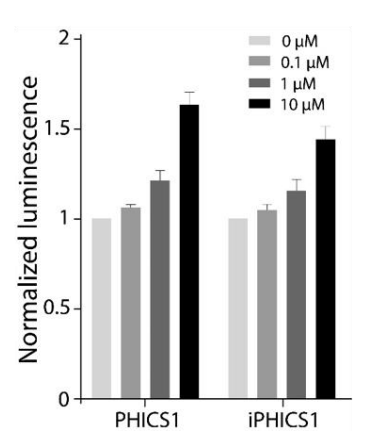

C

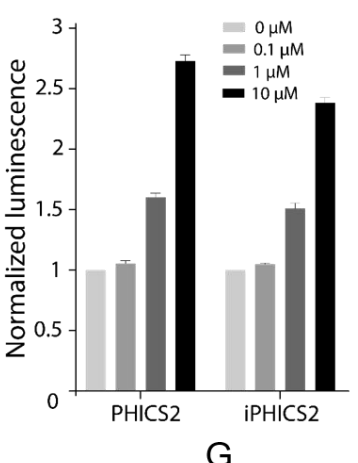

$\mathrm{D}$

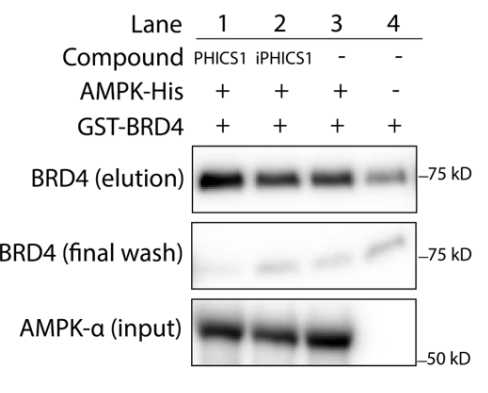

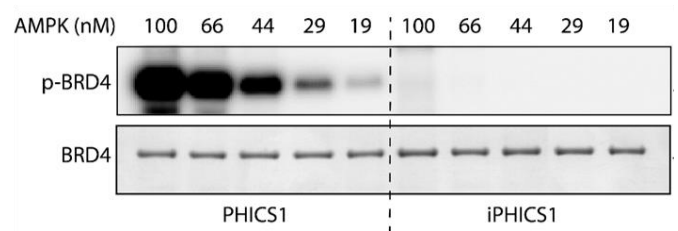

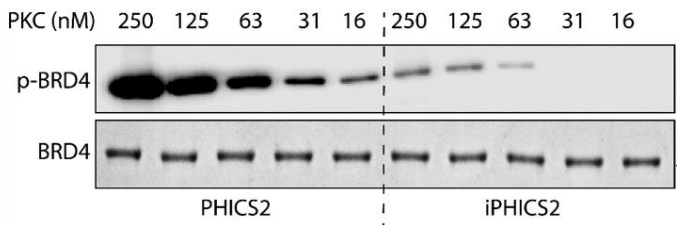

Figure S7. Validation of the inactive analogue. (A) Structures of the PHICS1, PHICS2 and their inactive analogues iPHICS1 and iPHICS2. (B) ADP-Glo with SAMStide peptide as the substrate to compare the AMPK activation by PHICS1 and iPHICS1. (C) ADP-Glo with CREBtide peptide as the substrate to compare the PKC activation by PHICS2 and iPHICS2. (D) PHICS1 induced ternary complex formation of AMPK and BRD4 observed by pulldown assay. (E) Western blot analysis of His-tagged BRD4 (49-460) phosphorylation by AMPK in the presence of PHICS1. (F) Effect of AMPK concentration on BRD4 phosphorylation in the presence of PHICS1 or iPHICS1. (G) Effect of PKC concentration on BRD4 phosphorylation in the presence of PHICS2 or iPHICS2.

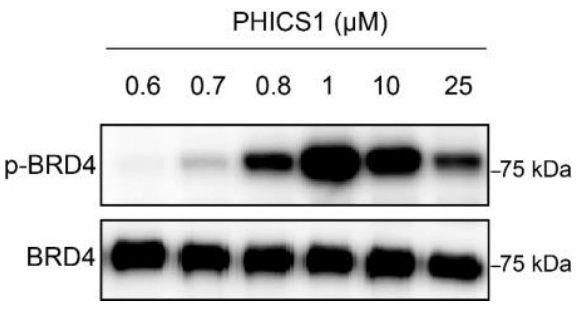

Figure S8. Bell-shaped dependence of BRD4 phosphorylation as a function of PHICS1 concentration analyzed via western blot. 


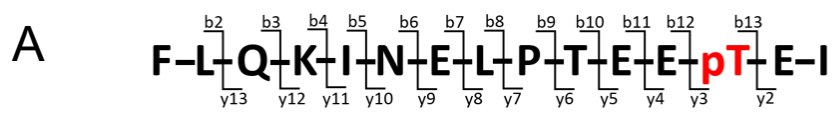

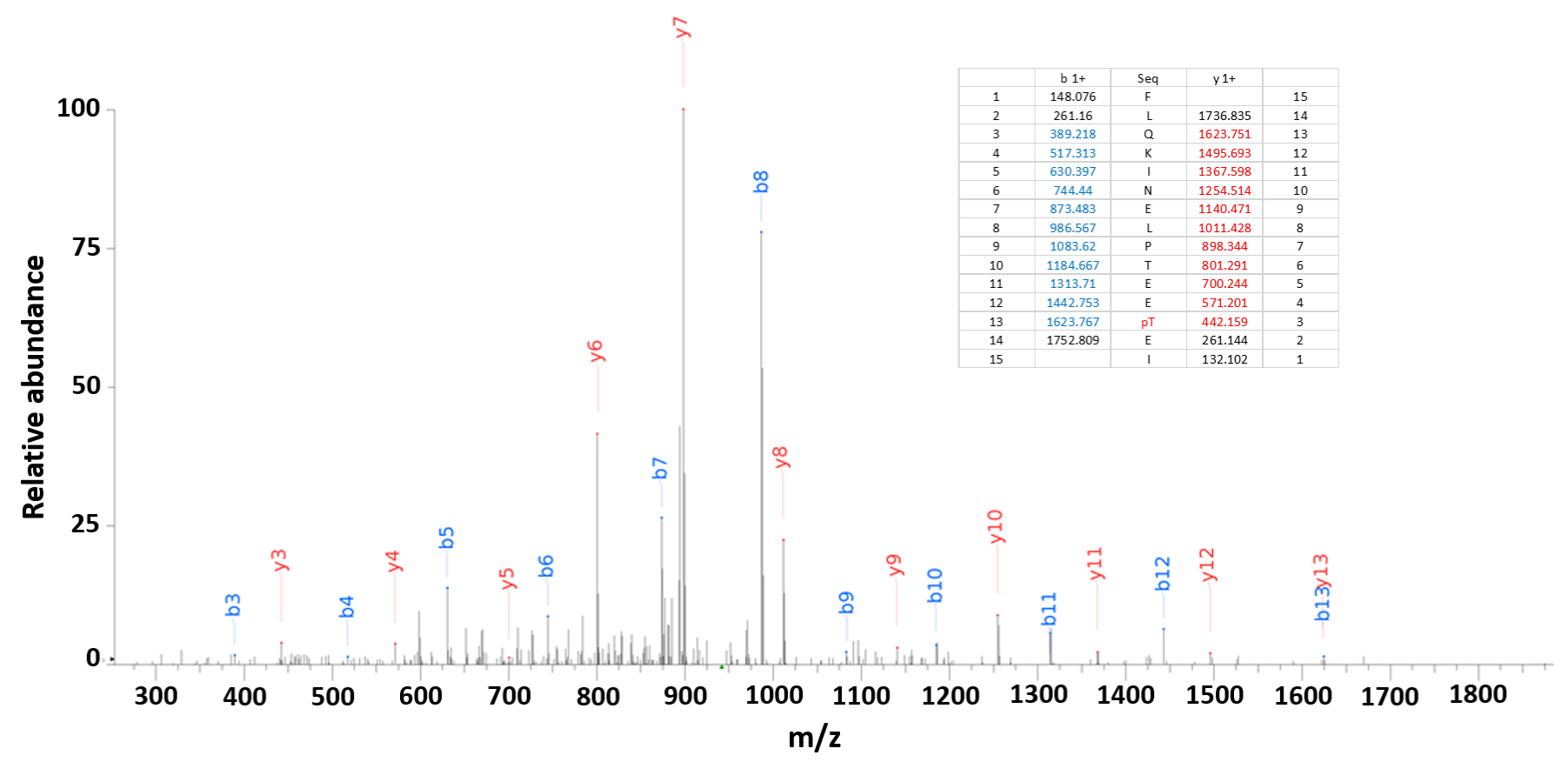

B

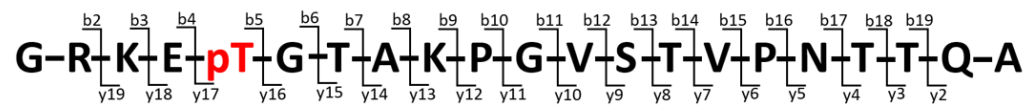

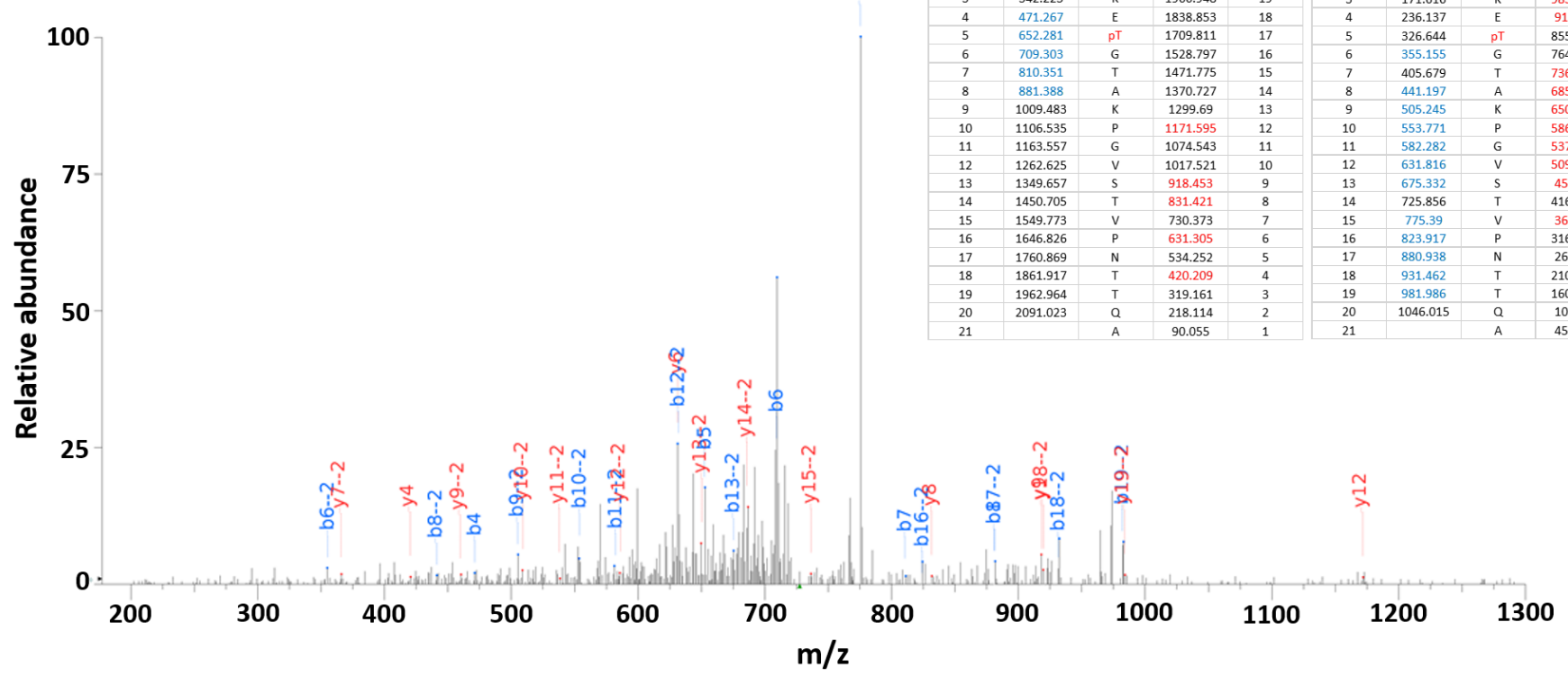


C S-T-

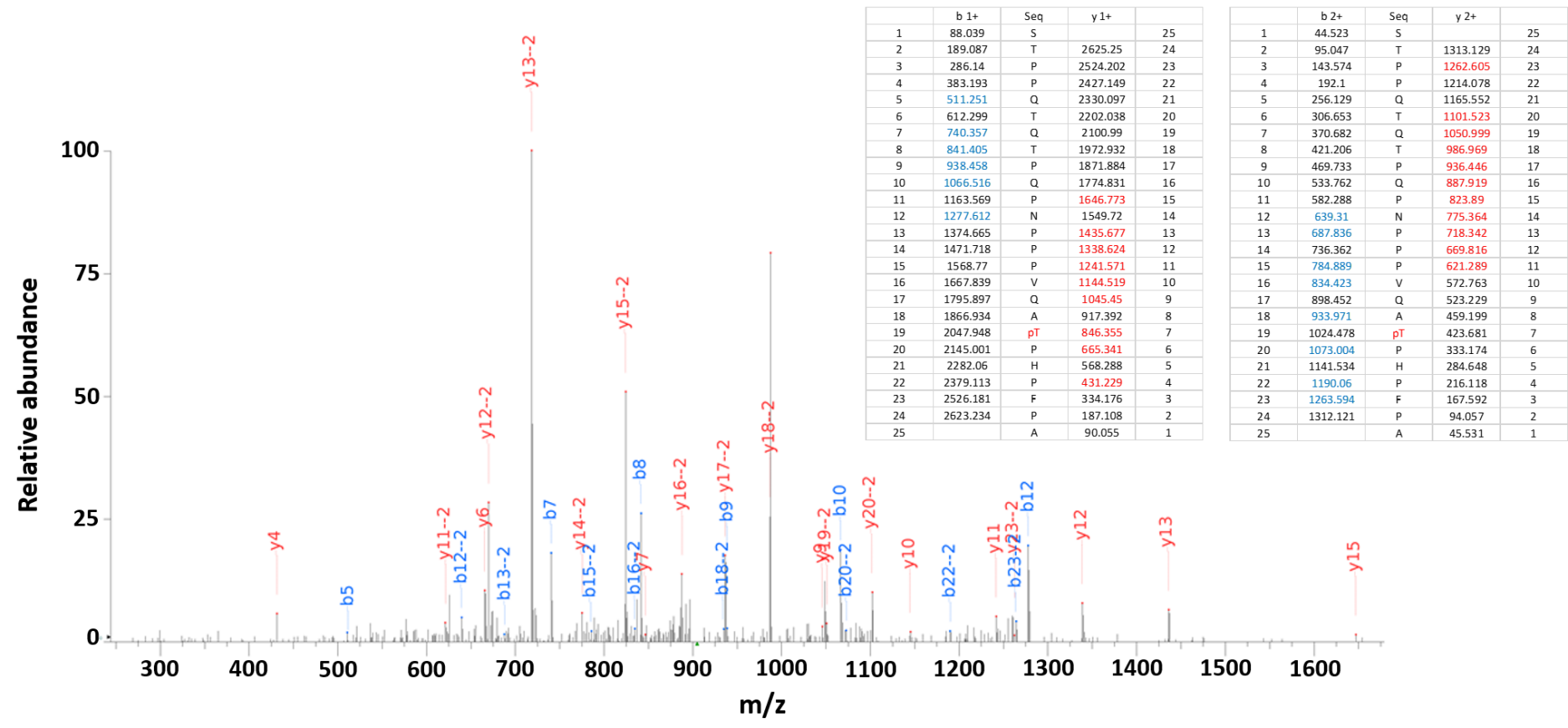

D
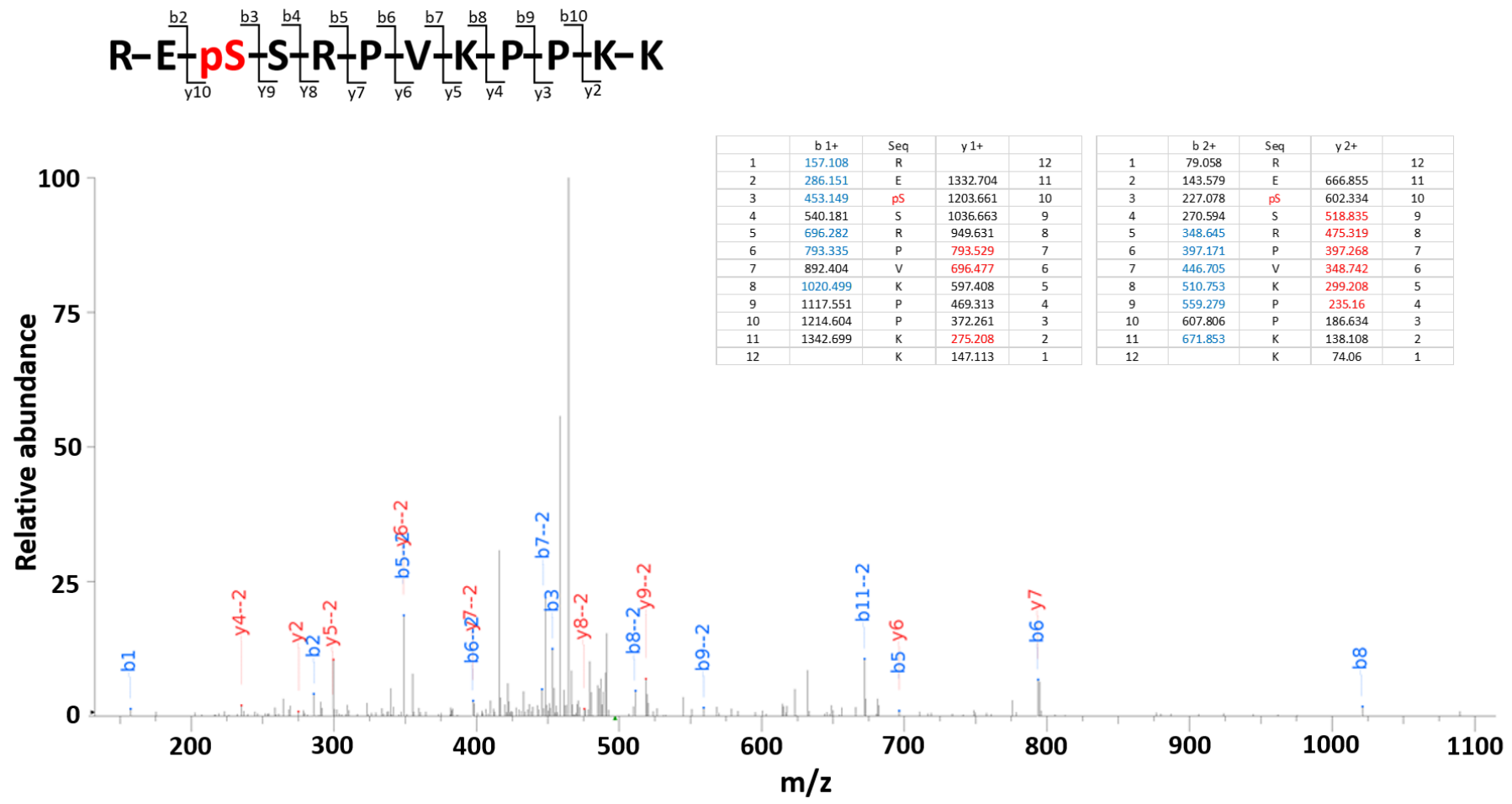
$E$

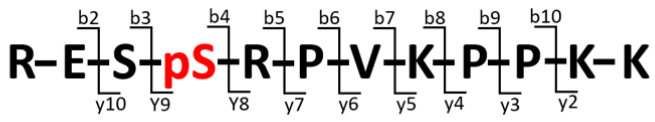

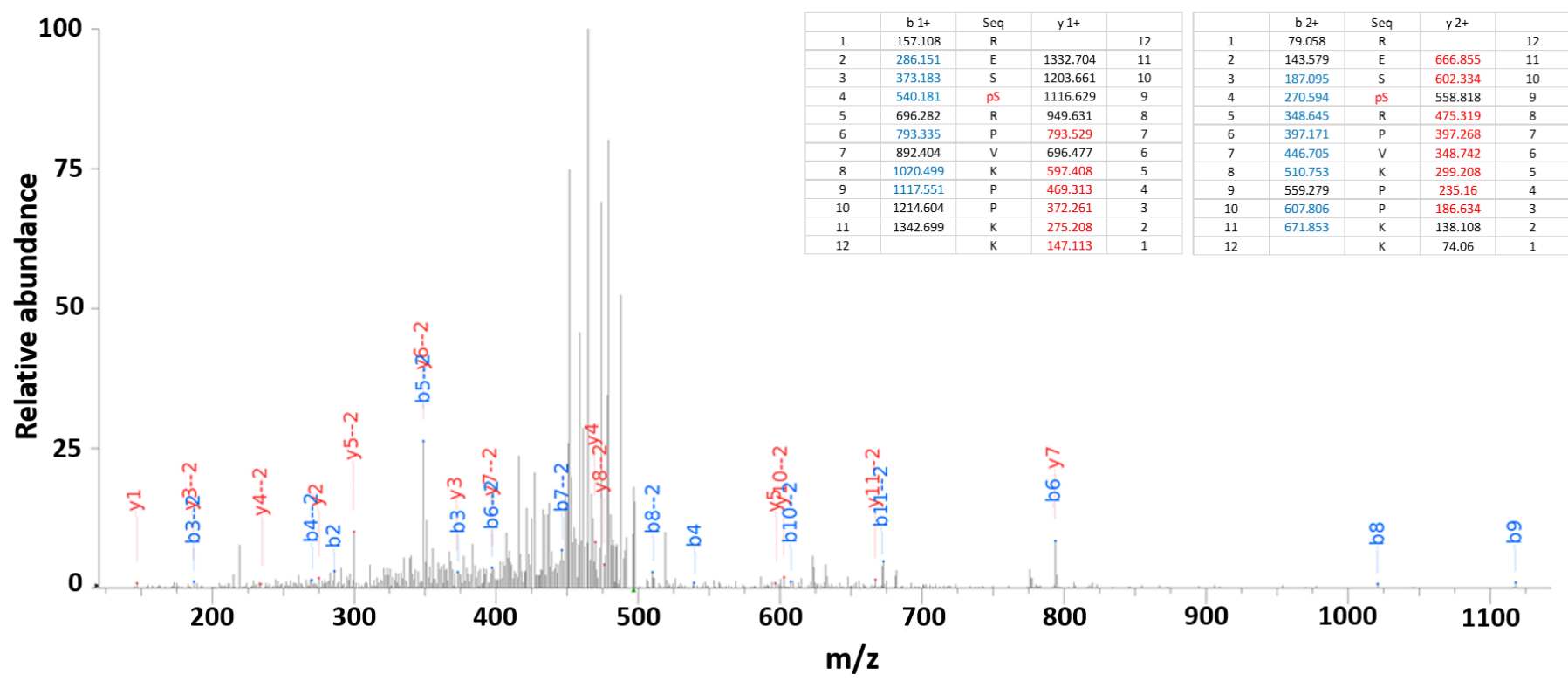

Figure S9. Mass spectrometry identification of BRD4 phosphorylation by AMPK in the presence of PHICS1. Spectra for the peptides with phosphorylated (A) T169, (B) T186, (C) T221, (D) S324 and (E) S325. The fragmentation pattern is shown in each spectrum.

A

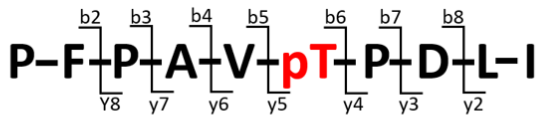

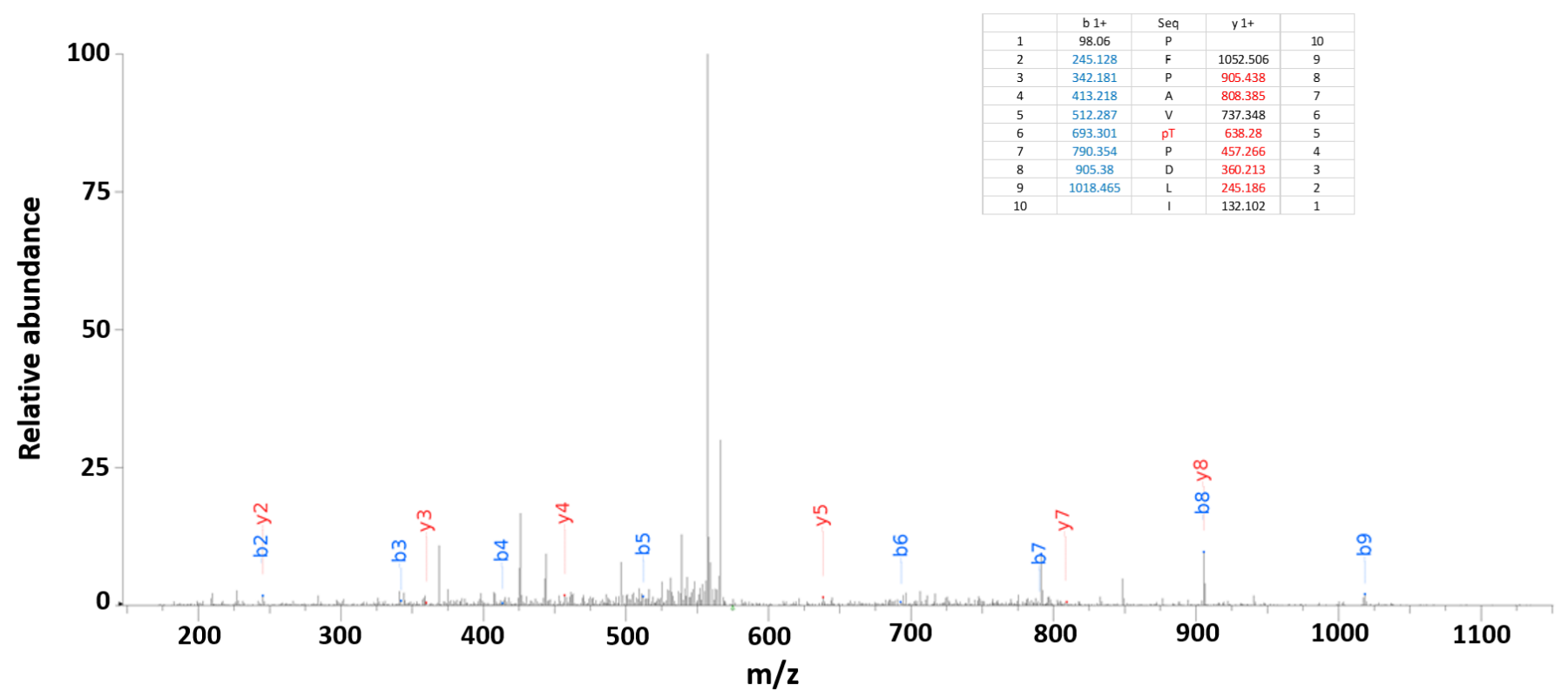


B

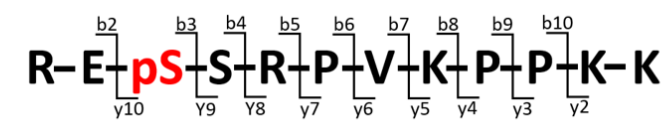

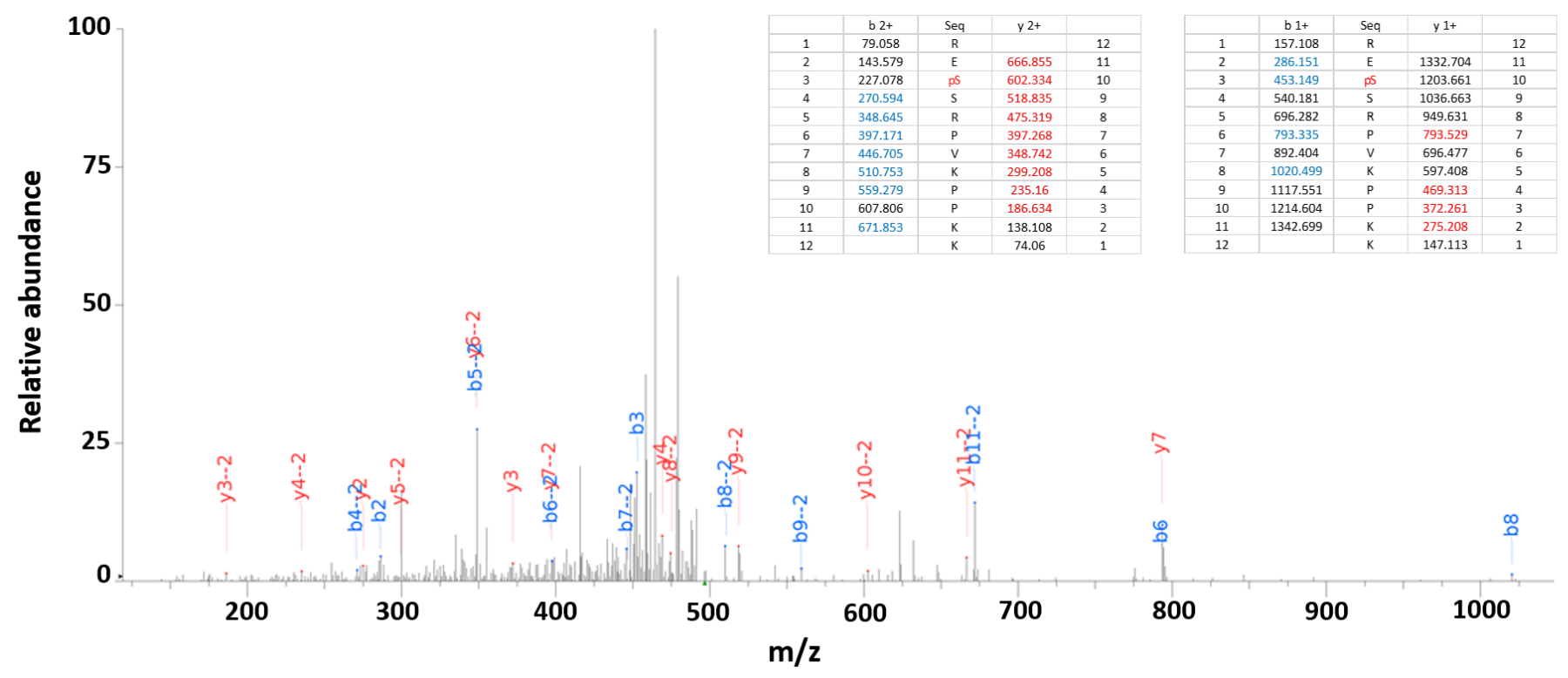

C
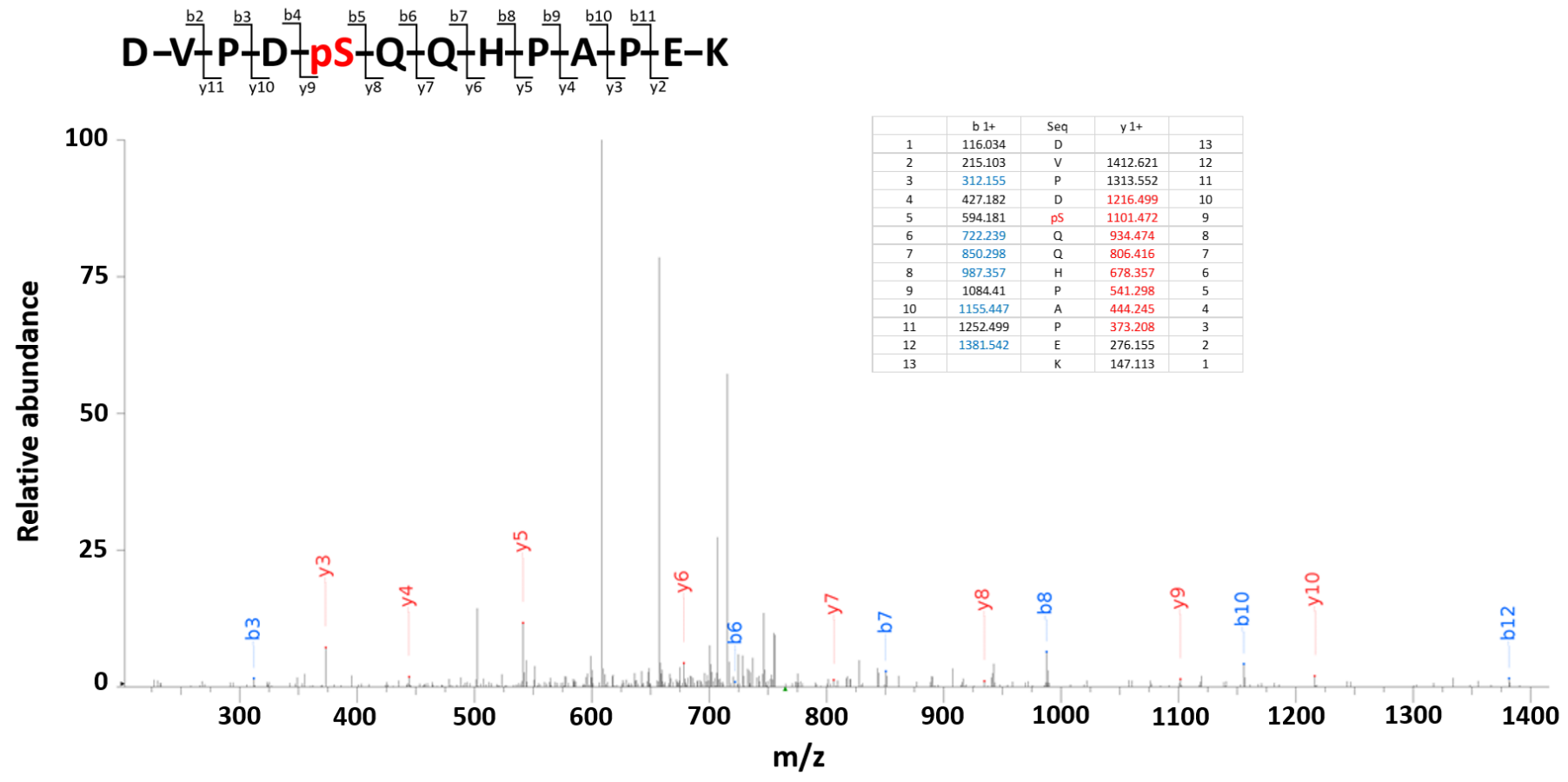

Figure S10. Mass spectrometry identification of BRD4 phosphorylation by PKC in the presence of PHICS2. Spectra for the peptides with phosphorylated (A) T229, (B) S324 and (C) S338. The fragmentation pattern is shown in each spectrum. 


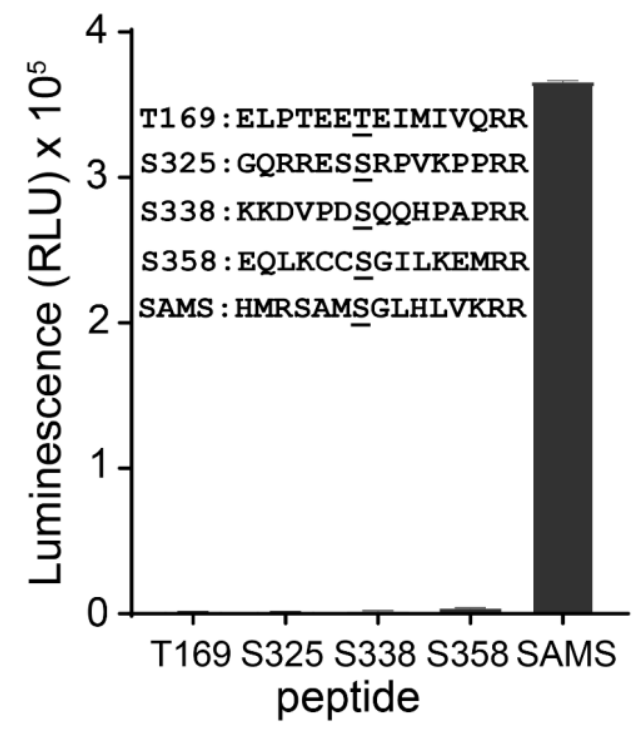

Figure S11. ADP-Glo assay for AMPK-mediated phosphorylation of different peptide sequences from BRD4 or the peptide derived from AMPK substrate ACC (SAMS peptide).

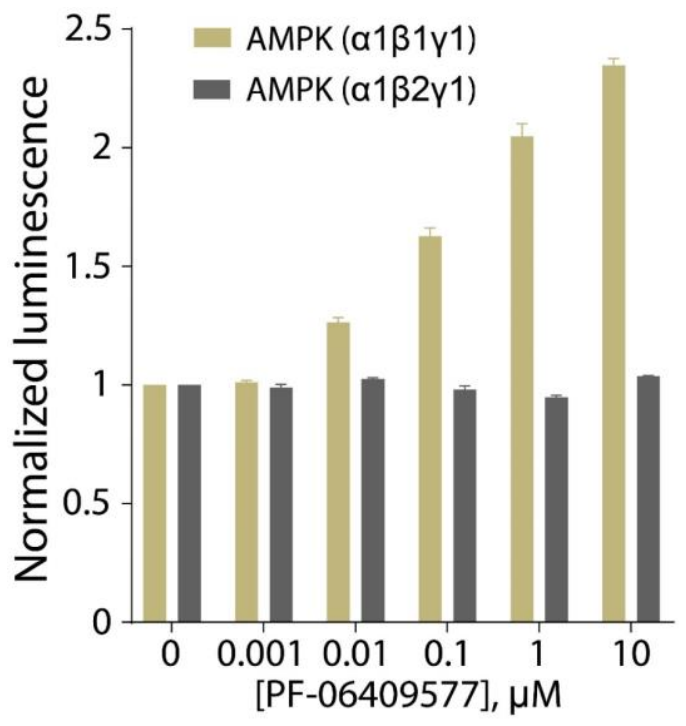

Figure S12. ADP-Glo assay for the activation of different AMPK isoforms by PF-06409577. 


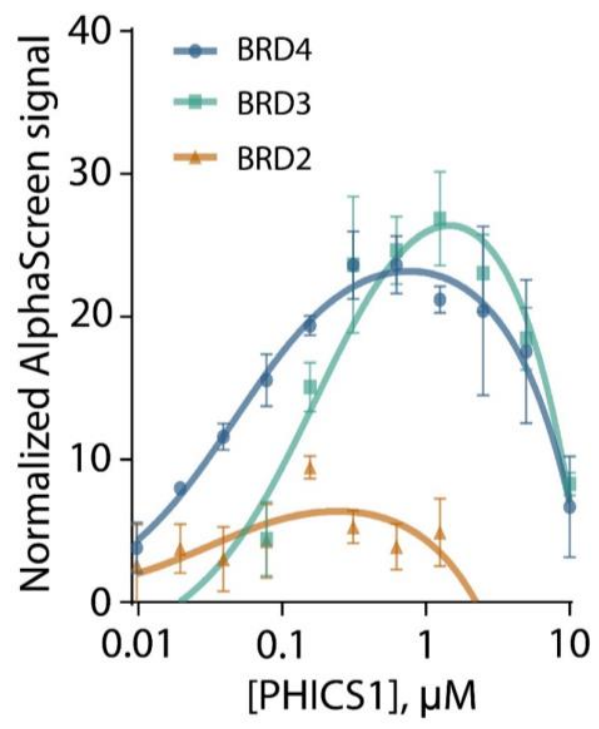

Figure S13. AlphaScreen assay for the ternary complex formation between AMPK, PHICS1, and different BRD proteins.
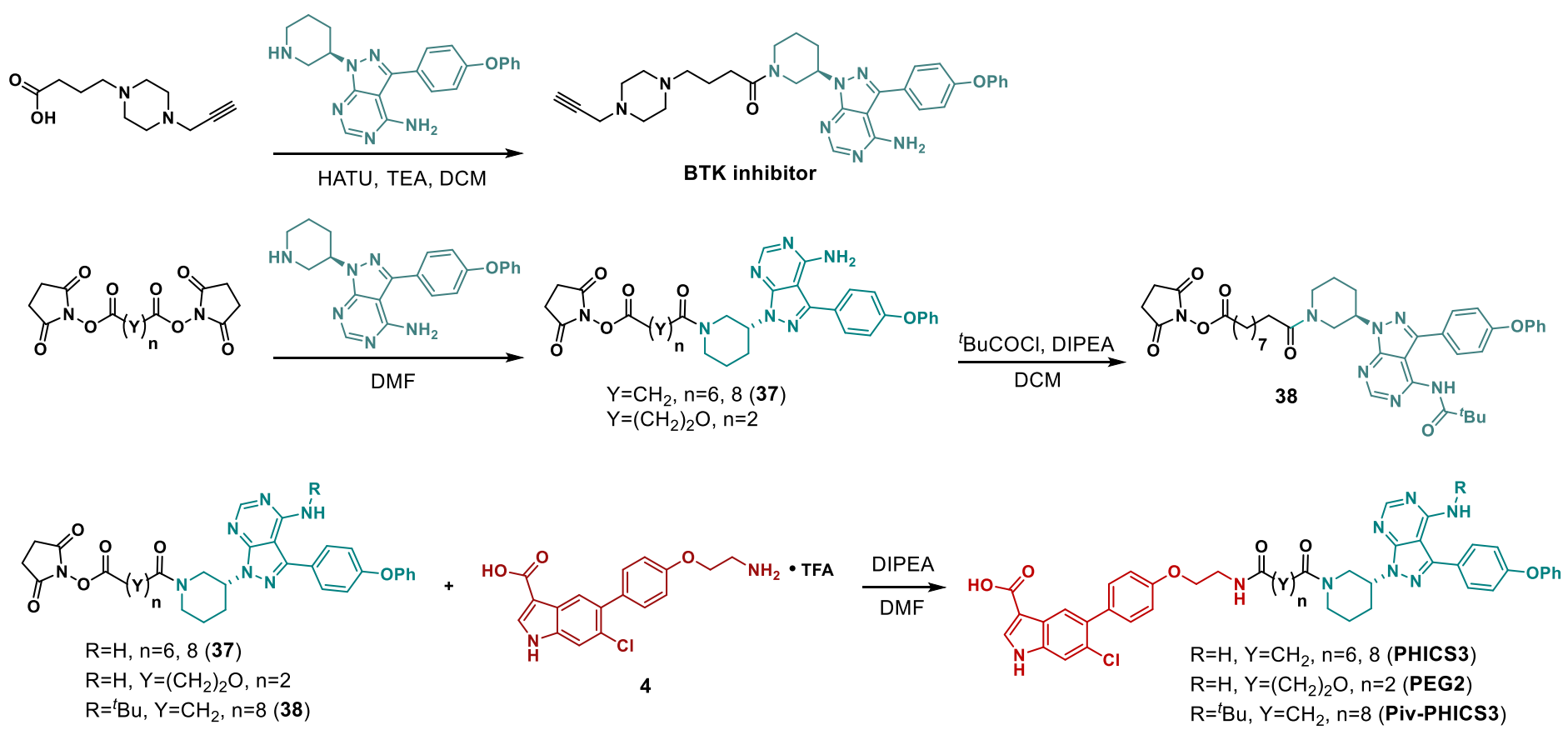

Figure S14. Synthesis of noncovalent BTK inhibitor, PHICS3, its analogues with different linkers and inactive control Piv-PHICS3. 

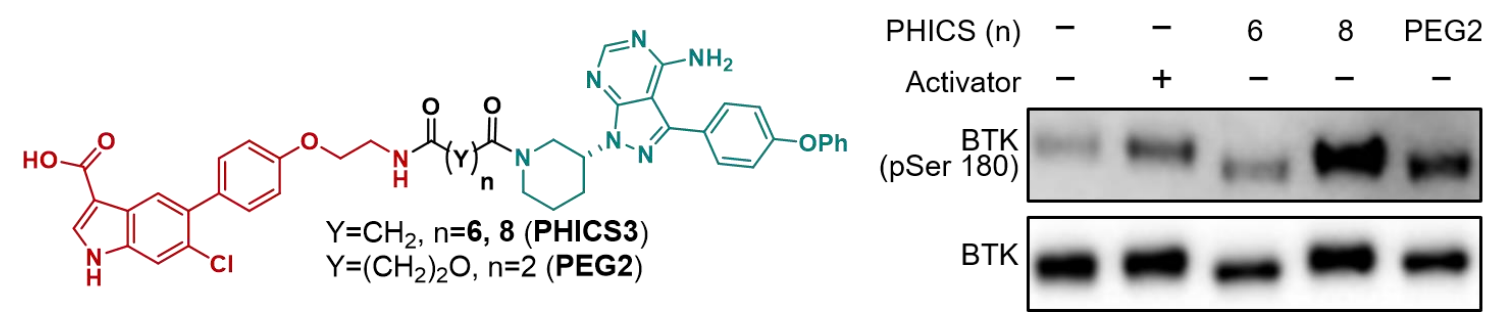

Figure S15. In-vitro biochemical validation of BTK phosphorylation by AMPK in the presence of PHICS. Western blot analysis for BTK phosphorylation using $10 \mu \mathrm{M}$ BTK targeting AMPK-PHICS with different linkers for identification of the optimal molecule for further studies. Molecule with 8 carbon alkyl linker (PHICS3) was identified as the most optimal molecule for phosphorylation.

A

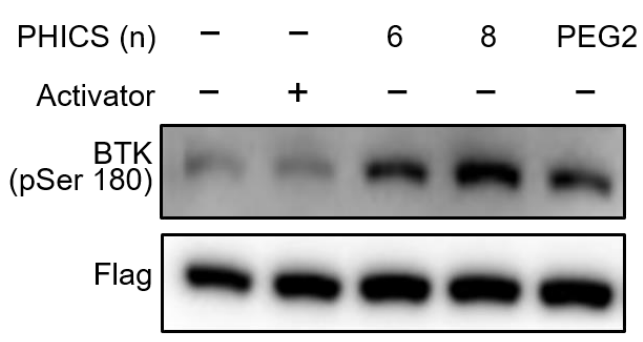

C

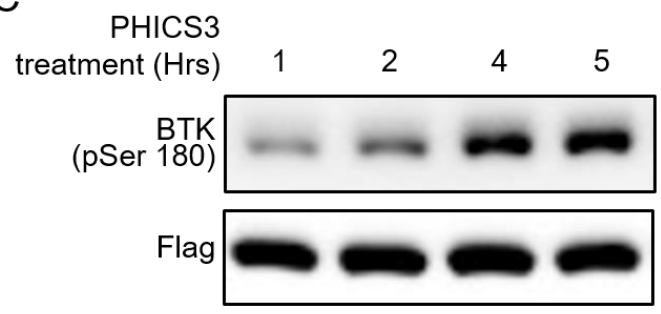

B

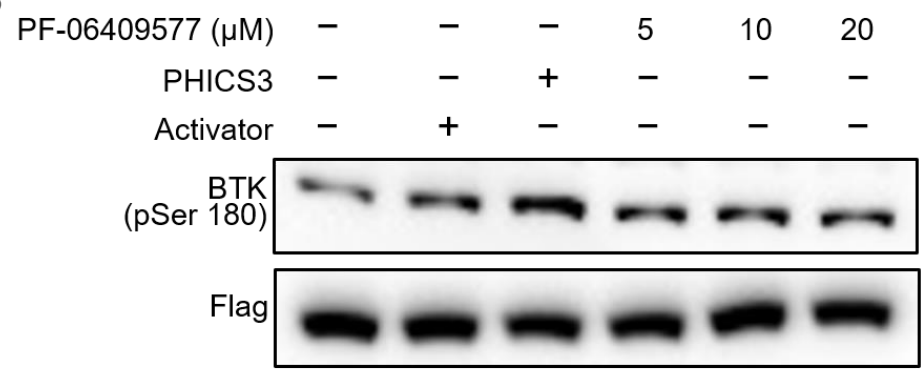

D

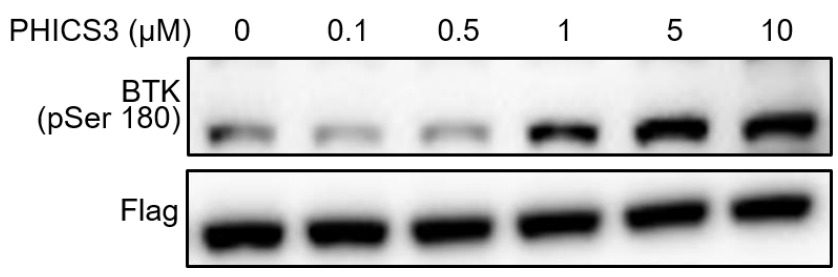

Figure S16. Cell base studies for PHICS mediated BTK phosphorylation by AMPK. (A) Western blot analysis for phosphorylation of Flag-BTK overexpressed in HEK293 cells using PHICS with different linkers. Cell were treated with compounds for $4 \mathrm{hrs}$ and phosphorylation was detected by phospho-BTK (Ser180) antibody. Molecule with 8 carbon alky linker (PHICS3) was identified as the optimal molecule for phosphorylation. (B) Western blot analysis to compare BTK Ser180 phosphorylation in the presence of $5 \mu \mathrm{M}$ PHICS3, $5 \mu \mathrm{M}$ activator, or increasing concentrations of a potent AMPK activator, PF-06409577. (C) Time-dependent and (D) PHICS3 dose-dependent BTK phosphorylation observed by western blot. For the time-dependent study, $5 \mu \mathrm{M}$ of PHICS3 was used. 
A

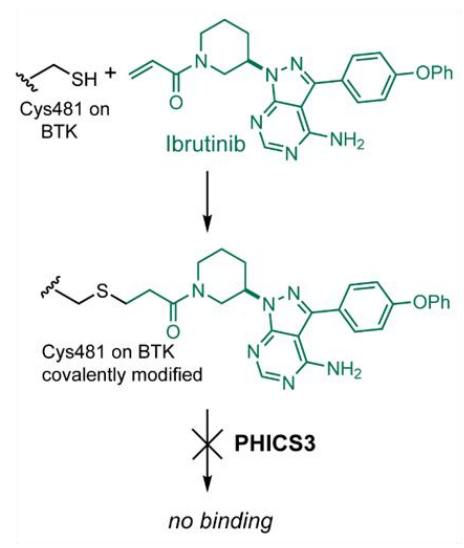

B

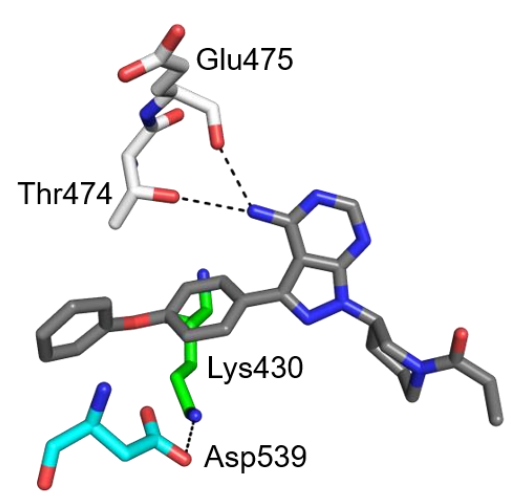

C

\begin{tabular}{|c|c|c|c|c|c|c|c|c|c|c|c|c|}
\hline BTK & \multicolumn{3}{|c|}{ WT } & \multicolumn{3}{|c|}{ T474A } & \multicolumn{3}{|c|}{$\mathrm{K} 430 \mathrm{R}$} & \multicolumn{3}{|c|}{ D539N } \\
\hline PHICS3 & - & - & + & - & - & + & - & - & + & - & - & + \\
\hline Activator & - & + & - & - & + & - & - & + & - & - & + & - \\
\hline $\begin{array}{r}\text { BTK } \\
\text { (pSer 180) }\end{array}$ & $\infty$ & $\omega$ & - & $\infty$ & $\operatorname{riv}$ & 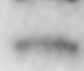 & $\omega$ & $m$ & $\infty$ & 20 & $x^{7}=$ & $-\infty$ \\
\hline
\end{tabular}

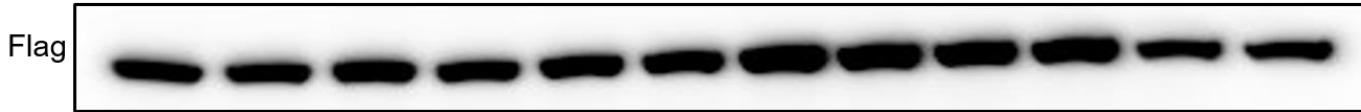

Figure S17. Validation of PHICS3 target engagement with BTK in cells. (A) Structure of Ibrutinib and the covalent binding of Ibrutinib to BTK. Pretreatment of cells with Ibrutinib leads to covalent irreversible modification of Cys481 and blocks binding of PHICS3 to BTK. (B) Crystal structure of Ibrutinib bound to BTK (PDB ID: 5P9I) with key interactions. Thr474 forms hydrogen bond with the 4-amino group of Ibrutinib. Asp539 (cyan) forms $\mathrm{H}$ bond with Lys430 (green), to stabilize Ibrutinib's binding pocket. (C) Detection of S180 phosphorylation in T474A, K430R and D539N variants of BTK compared to the WT. 


\section{Materials and methods}

\subsection{Materials and general procedures}

AMPK $\alpha 1 \beta 1 \gamma 1$-His (P47-10H), AMPK $\alpha 1 \beta 2 \gamma 1$-His (P50-10H), GST-PKC $\alpha$ (P61-18G), GST-PKC $\beta$ I (P62-18G), GST-PKCßIIßII (P63-18G), GST-PKC $\gamma$ (P66-18G), GST-PKCס (P64-18G), kinase assay buffer III 5x (K03-09), SAMStide peptide, HMRSAMSGLHLVKRR (S07-58) and CREBtide peptide, KRREILSRRPSYR (C50-58) were all purchased from SignalChem. GST-BRD4 ((BD1 and BD2 (49-460))(31044) and His-BRD4 ((BD1 and BD2 $(49-460))(31045)$, GST-BRD3 ((BD1 and BD2 (29-417))(31035) and GST-BRD2 ((BD1 and BD2 (65459))(31024) were purchased from BPS Bioscience. BTK-His (1-659) (10578-H08B) was purchased from Sino Biological Inc. OptiPlate-384 (White Opaque 384-well Microplate, 6007290), Nickel Chelate AlphaLISA Acceptor Beads (AL108C), and Alpha Glutathione Donor beads (6765300) were all purchased from Perkin Elmer. AMPK activator, PF-06409577, was purchased from Tocris Bioscience (Cat\#6114). pcDNA3.1(+) BTK-Flag plasmid was purchased from GenScript (Cat\#OHu20257). TransIT®-293 Transfection Reagent was purchased from Mirus (MIR 2700). M-PER ${ }^{\mathrm{TM}}$ Mammalian Protein Extraction Reagent (Cat\#78501), Halt ${ }^{\mathrm{TM}}$ Protease and Phosphatase Inhibitor Cocktail (100X)(Cat\#78440), Pierce ${ }^{\mathrm{TM}}$ BCA Protein Assay Kit (Cat\#23225) and NuPAGE 4-12\% Bis-Tris Protein Gels (NP0336 or NP0335) were purchased from ThermoFisher. Ni-NTA agarose beads were purchased from Qiagen. Anti-FLAG® M2 Magnetic Beads was purchased from Sigma (Cat\#M8823). Q5® Site-Directed Mutagenesis Kit was purchased from New England Biolabs (E0554S).

For chemical synthesis, all reagents were purchased and used as received from commercial sources without further purification. Reactions were performed in round-bottom flasks stirred with Teflon®-coated magnetic stir bars. Moisture and air-sensitive reactions were performed under a dry nitrogen/argon atmosphere. Moisture and air-sensitive liquids or solutions were transferred via nitrogen-flushed syringes. As necessary, organic solvents were degassed by bubbling nitrogen/argon through the liquid. The reaction progress was monitored by thin-layer chromatography (TLC) and ultra-performance liquid chromatography mass spectrometry (UPLC-MS). Flash column chromatography was performed using silica gel (60 ̊̊ mesh, 20-40 $\mu \mathrm{m}$ ) on a Teledyne Isco CombiFlash Rf system. Analytical TLC was performed using Merck Silica gel 60 F254 pre-coated plates (0.25 mm); illumination at $254 \mathrm{~nm}$ allowed the visualization of UV-active material, and phosphomolybdic acid (PMA) stain was used to visualize UV-inactive material. UPLC-MS was performed on a Waters ACQUITY UPLC I-Class 
PLUS System with an ACQUITY SQ Detector 2. Nuclear magnetic resonance (NMR) spectra were collected on a Bruker AVANCE III HD $400 \mathrm{MHz}$ spectrometer at room temperature $\left({ }^{1} \mathrm{H} \mathrm{NMR}, 400 \mathrm{MHz} ;{ }^{13} \mathrm{C}, 101 \mathrm{MHz}\right)$ at the Broad Institute of MIT and Harvard. ${ }^{1} \mathrm{H}$ and ${ }^{13} \mathrm{C}$ chemical shifts are indicated in parts per million (ppm) and internally referenced to residual solvent signals. NMR solvents were purchased from Cambridge Isotope Laboratories, Inc., and NMR data were obtained in $\mathrm{CDCl}_{3}$ and $\mathrm{DMSO}-\mathrm{d}_{6}$. Data for ${ }^{1} \mathrm{H}$ NMR are reported as follows: chemical shift value in ppm, multiplicity $(s=$ singlet, br $s=$ broad singlet, $d=$ doublet, $t=$ triplet, $d d=$ doublet of doublets, and $\mathrm{m}=$ multiplet), integration value, and coupling constant value in $\mathrm{Hz}$. Tandem liquid chromatography-mass spectrometry (LCMS) was performed on a Waters 2795 separations module with a 3100 mass detector.

\subsection{Molecular docking}

Docking was performed with the standard precision protocol using Schrödinger Maestro v11.6. The ligands were prepared by generating possible states at pH $7.0 \pm 2.0$ using Epik, desalted, and subjected to OPLS3e force field. 2D ligand interaction maps were generated from the docking results to predict linker attachment sites.

\subsection{ADP-Glo kinase assay to validate the kinase activation by PHICS molecule}

ADP-Glo assay ${ }^{1}$ was performed in the presence of kinase activators, modified activators, PHICS intermediates (activator + linker), and final bifunctional PHICS molecules to validate their potential to activate the kinases (AMPK $\alpha 1 \beta 1 \gamma 1$ or $\mathrm{PKC} \alpha$ ) and to confirm their binding to the kinases. In a 96 well plate (white, flat bottom), concentration series $(0.001,0.01,0.1,1$ and $10 \mu \mathrm{M})$ of AMPK activator (PF-06409577), AMPK PHICS intermediates (AMPK activator, AMPK activator with linker), AMPK-BRD4 PHICS1 and iPHICS1 molecules were prepared using kinase assay buffer (40 mM Tris- $\mathrm{HCl} \mathrm{pH} 7.5,20 \mathrm{mM} \mathrm{MgCl} 2,0.1 \mathrm{mg} / \mathrm{ml} \mathrm{BSA,} 50 \mu \mathrm{M}$ DTT, $1 \%$ DMSO) and incubated with $5 \mathrm{ng}$ of AMPK and $0.2 \mu \mathrm{g} / \mu \mathrm{L}$ SAMStide peptide in the presence of $150 \mu \mathrm{M}$ ATP. After $2 \mathrm{hrs}$ of incubation at room temperature, ADP-Glo reagent was added to the kinase reaction mixture in a 1:1 ratio and maintained the reaction mixture for another $40 \mathrm{~min}$ at room temperature. Finally, kinase detection reagent was added to the mixture in a 1:2 ratio and incubated for another $30 \mathrm{~min}$ at room temperature before recording luminescence by Envision 2104 plate reader (PerkinEImer). Kinase activation by PHICS molecule was calculated after removing the background signal coming from the no AMPK control and data was plotted using GraphPad PRISM version 8.1.1 normalized to DMSO control. 
ADP-Glo assay was performed with PHICS (PKC) similarly with some modifications as follows. In a 96 well plate (white, flat bottom), similar concentration series of PKC activator, PKC-BRD4 PHICS2 and iPHICS2 were prepared using same kinase assay buffer and incubated with $2 \mathrm{ng}$ of PKC, $0.2 \mu \mathrm{g} / \mu \mathrm{L}$ CREBtide peptide and 50 $\mu \mathrm{M}$ ATP for $1 \mathrm{hr}$ at room temperature before incubation with ADP-Glo assay reagents.

\subsection{ADP-Glo kinase assay to evaluate the catalytic nature between kinase and PHICS molecules}

ADP-Glo assay was performed with a mixture of kinase, BRD4-GST (BD1 and BD2) and PHICS molecule to determine the enzyme turnover efficiency of PHICS (1 and 2) compared to the iPHICS (1 and 2). Initially, $1 \mu \mathrm{M}$ of PHICS1 (AMPK-BRD4) and iPHICS1 were prepared in a 96 well plate (white, flat bottom) using kinase assay buffer (40 mM Tris-HCl pH 7.5, $20 \mathrm{mM} \mathrm{MgCl2,} 0.1 \mathrm{mg} / \mathrm{ml}$ BSA, $50 \mu \mathrm{M}$ DTT, 1\% DMSO) and incubated with 20 nM AMPK and $700 \mathrm{nM}$ BRD4-GST (BD1 and BD2) for 2 hrs at room temperature in the presence of $150 \mu \mathrm{M}$ ATP. Then ADP-Glo assay reagents were added similarly and luminescence was recorded using Envision 2104 plate reader (PerkinElmer). The actual signal coming from the PHICS1 mediated kinase reaction (20 nM AMPK, $1 \mu \mathrm{M}$ PHICS1, $700 \mathrm{nM}$ BRD4-GST and $150 \mu \mathrm{M}$ ATP) was calculated by subtracting the luminescence signal of inactive control (20 nM AMPK, $1 \mu \mathrm{M}$ iPHICS, 700 nM BRD4-GST and $150 \mu \mathrm{M}$ ATP). ADP generation during the kinase reaction was determined through a standard curve (luminescence (RLU) versus \% ATP to ADP conversion) which was plotted according to the Promega specifications.

The same protocol was followed for PHICS2 (PKC-BRD4) as well. Initially, $1 \mu \mathrm{M}$ of PHICS2 and iPHICS2 were prepared in a 96 well plate (white, flat bottom) using kinase assay buffer and incubated with 50 nM PKC and 700 nM BRD4-GST (BD1 and BD2) for $1 \mathrm{hr}$ at room temperature in the presence of $50 \mu \mathrm{M}$ ATP before adding ADPGlo reagents.

\subsection{ADP-Glo kinase assay to assess the BRD4 peptide phosphorylation}

ADP-Glo assay was performed with several synthesized peptides from BRD4 protein to evaluate the preference of AMPK towards phosphorylating these peptide substrates. Peptide regions shown below were selected based on our mass spectrometry analysis and purchased from GenScript.

S325 = GQRRESSRPVKPPRR (Confirmed by our Mass spec as a target of phosphorylation) T169 = ELPTEETEIMIVQRR (Confirmed by our Mass spec as a target of phosphorylation) 
S338 = KKDVPDSQQHPAPRR (Potential phosphorylation site on BRD4)

S358 = EQLKCCSGILKEMRR (Potential phosphorylation site on BRD4)

Kinase reaction was performed similarly by incubating $0.2 \mu \mathrm{g} / \mu \mathrm{L}$ of each peptide with $20 \mathrm{nM}$ AMPK for $2 \mathrm{hrs}$ at room temperature in the presence of $150 \mu \mathrm{M}$ ATP before adding the ADP-Glo reagents. ADP-Glo kinase assay with $0.2 \mu \mathrm{g} / \mu \mathrm{L}$ SAMStide peptide and $20 \mathrm{nM}$ AMPK was used as a positive control and luminescence signal generated from each BRD4 peptide was compared with this positive control to determine the preference of AMPK on phosphorylating these BRD4 peptides.

\subsection{AlphaScreen assay to determine the PHICS induced protein dimerization}

AlphaScreen assay ${ }^{2}$ was performed to validate the PHICS induced ternary complex formation between kinase (AMPK or PKC): PHICS molecule: BRD4 (BD1 and BD2). Initially, concentration series of PHICS (AMPK-BRD4) with different linkers ( $n=3,5,7,9$ and 11) or iPHICS1 with DMSO control were prepared in a white opaque 384well microplate using a dilution assay buffer (50 mM HEPES pH 7.4, $150 \mathrm{mM} \mathrm{NaCl}, 0.1 \% \mathrm{w} / \mathrm{v} \mathrm{BSA}, 0.01 \% \mathrm{v} / \mathrm{v}$ Tween 20) with 1\% DMSO in the final mixture. Then 7 nM AMPK (6x His tag) and 67 nM BRD4-GST were added to the mixture and incubated at room temperature for $1 \mathrm{hr}$. Then, Nickel Chelate AlphaLISA acceptor beads (PerkinElmer) and Glutathione donor beads (PerkinElmer) were added to the mixture in a final concentration of $20 \mu \mathrm{g} / \mathrm{mL}$. Following $1 \mathrm{hr}$ incubation at room temperature, luminescence was recorded using Envision 2104 plate reader (PerkinElmer). Normalized luminescence value was calculated after removing background signals from DMSO control or no protein wells. Data were analyzed and plotted using GraphPad PRISM version 8.1.1. AlphaScreen assay was performed similarly to determine the ternary complex formation between AMPK: PHICS1: BRD3 (BD1 and BD2) or BRD2 (BD1 and BD2) as well. Initially, a concentration series of PHICS1 (AMPK-BRD4) was prepared using dilution buffer and incubated with $7 \mathrm{nM}$ AMPK and $67 \mathrm{nM}$ BRD3-GST or BRD2-GST for $1 \mathrm{hr}$ at room temperature before addition of acceptor and donor beads.

A similar approach was followed to determine the PHICS (PKC-BRD4) induced ternary complex formation between PKC: PHICS: BRD4-GST (BD1 and BD2). Initially, a concentration series of PHICS (PKC-BRD4) with different linkers $(31,33,34,35$, and 36$)$ and iPHICS2 with DMSO control were prepared in a white opaque 384well microplate using a dilution assay buffer with 1\% DMSO in the final mixture. Then $10 \mathrm{nM} \mathrm{PKC-GST}$ and 100 
nM BRD4 (6x His tag) were added to the mixture and incubated at room temperature. Following $1 \mathrm{hr}$ incubation, acceptor beads and donor beads were added to the system.

\subsection{Pull-down assay to determine the ternary complex formation}

The interaction between AMPK and BRD4 via PHICS1 was determined by in vitro pull-down assay. His-tagged AMPK (70 nM) was immobilized on Ni-NTA agarose beads by incubating at $4^{\circ} \mathrm{C}$ in binding buffer (50 mM HEPES $\mathrm{pH}$ 7.4, $150 \mathrm{mM} \mathrm{NaCl}, 0.1 \%$ w/v BSA, 0.01\% v/v Tween 20, $10 \mathrm{mM}$ imidazole). After $1 \mathrm{hr}$, beads were washed twice and incubated with BRD4-GST $(300 \mathrm{nM})$ and PHICS1 or iPHICS1 $(1 \mu \mathrm{M})$ for $4 \mathrm{hrs}$ at $4^{\circ} \mathrm{C}$. Next, the beads were extensively washed, mixed with SDS loading buffer and heated for 5 min at $95^{\circ} \mathrm{C}$. Western blot analysis was performed with antibodies against AMPK-a (Cell Signaling, Cat\#5832) and BRD4 (Biovision, Cat\# 6644).

\subsection{Immunoblotting analysis to confirm the BRD4 phosphorylation in vitro}

Proximity driven phosphorylation at Ser/Thr on BRD4 induced by PHICS was confirmed through western blotting using phospho-(Ser/Thr) kinase substrate motif antibodies. Initially, $10 \mu \mathrm{M}, 5 \mu \mathrm{M}$, and $1 \mu \mathrm{M}$ concentrations of PHICS (AMPK-BRD4) with different linkers $(n=3,5,7,9$, and 11) or iPHICS1 and DMSO control were prepared using $1 \mathrm{x}$ kinase assay buffer with 1\% DMSO. Then kinase reaction was performed in the presence of $20 \mathrm{nM}$ AMPK, 700 nM BRD4-GST, and $150 \mu \mathrm{M}$ ATP for 2 hrs at room temperature. In another experiment, the kinase reaction was performed with diluting concentrations of PHICS1 in a similar manner. In addition to BRD4-GST, the same kinase reaction was performed with 700 nM BRD3-GST (BD1 and BD2) and 700 nM BRD3-GST(BD1 and BD2) in the presence or absence of PHICS1. Importance of GST tag on BRD4 for PHICS induced phosphorylation was validated with BRD4-(6x His tag) (BD1 and BD2) (700 nM) version following the same kinase assay. Following 2 hrs of incubation, kinase reaction was quenched by adding SDS loading buffer. Proteins were resolved by NuPAGE 4-12\% Bis-Tris protein gels and transferred to a PVDF membrane. Then the membrane was incubated at room temperature for $1 \mathrm{hr}$ in a blocking buffer (TBS with $0.1 \%$ tween 20 and $5 \%$ BSA). After that membrane was incubated with phospho-AMPK substrate motif [LXRXX(pS/pT) (Cell Signaling, Cat\#5759) (1:1000) primary antibody to detect the phosphorylation at Ser/Thr on BRD4 and anti-BRD4 antibody (Biovision, Cat\# 6644) (1:1000) to detect loading levels. Following overnight incubation at $4{ }^{\circ} \mathrm{C}$, the membrane was washed three times with TBST buffer (TBS with $0.1 \%$ tween 20). After that, the membrane was further 
incubated with appropriate HRP-conjugated secondary antibodies (Rabbit/ Mouse, Cell Signaling, Cat\#7074/ 7076) or IRDye 800CW/ IRDye 680RD secondary antibodies (Rabbit/ Mouse, LI-COR, Cat\# 926-32211/ 92668070) for $1 \mathrm{hr}$ at room temperature. After washing the membrane three times with TBST buffer, protein bands were visualized by either chemiluminescence (Azure Biosystems C600 imager) or NIR fluorescence (LI-COR Odyssey Imager). In another experiment, the kinase reaction was performed with $1 \mu \mathrm{M}$ of PHICS1 or iPHICS1 and the His-BRD4 (full length, Reaction Biology (RD-21-153)) phosphorylation was detected using phosphoSer484/488 antibody (a gift from Prof. C.M. Chiang). ${ }^{3}$

PHICS induced phosphorylation on BRD4 by PKC was also validated using similar conditions. Kinase buffer included with $1 \mu \mathrm{M}$ PHICS (PKC-BRD4) with different linkers (31, 32, 33, 34, and 35) or PPICS2 or DMSO control, $50 \mathrm{nM}$ PKC, $700 \mathrm{nM}$ BRD4-GST and $50 \mu \mathrm{M}$ ATP. Kinase reaction was performed for $1 \mathrm{hr}$ at room temperature before quenching with SDS loading buffer. Proteins were resolved in NUPAGE 4-12\% Bis-Tris protein gels and transferred to a PVDF membrane. After incubation of the membrane with the blocking buffer, phospho-PKC substrate motif $[(R / K) X p S X(R / K)]$ (Cell Signaling, Cat\#6967) (1:1000) antibody was added to the membrane and further incubated at $4{ }^{\circ} \mathrm{C}$ for overnight. HRP-conjugated secondary antibodies or IRDye $800 \mathrm{CW} /$ IRDye 680RD secondary antibodies were used to visualize the protein bands.

Similar approaches were followed to determine the phosphorylation of BRD4 with different AMPK and PKC isoforms as well as phosphorylation of different BRD proteins.

\subsection{Mass spectrometry analysis to identify the phosphorylated sites in BRD4}

Kinase reaction was performed in the presence of AMPK, BRD4, and PHICS, and mass spectrometry study was performed to determine the proximity driven phosphorylation sites on BRD4. AMPK-BRD4 PHICS induced kinase reaction was performed using $20 \mathrm{nM}$ AMPK, $700 \mathrm{nM}$ BRD4-GST, and $1 \mu \mathrm{M}$ PHICS1 or iPHICS1. PKC-

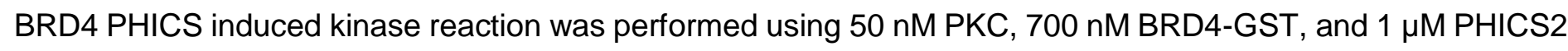
or iPHICS2. The reactions were quenched after 2 hrs incubation by adding $6 x$ loading dye. Proteins in each reaction mixture with PHICS1, iPHICS1, PHIC2, iPHICS2, and DMSO were resolved by NuPAGE 4-12\% BisTris protein gels and the gel slice with BRD4-GST was submitted to the Taplin Mass Spectrometry Facility in Harvard Medical School to determine the phosphorylation sites after digestion with trypsin or elastase. 


\subsection{Immunoblotting analysis to confirm the BTK phosphorylation in vitro}

PHICS3 induced phosphorylation of BTK was confirmed by western blotting using phospho-BTK (Ser180) antibody in-vitro. Initially, $10 \mu \mathrm{M}$ concentration of PHICS (AMPK-BTK) with different linkers ( $\mathrm{n}=6,8$ and PEG2), AMPK activator, and DMSO control were prepared using 1x kinase assay buffer with 1\% DMSO. Then kinase reaction was performed in the presence of $20 \mathrm{nM}$ AMPK, $700 \mathrm{nM} \mathrm{BTK}$, and $150 \mu \mathrm{M}$ ATP for 2 hrs at room temperature. Following incubation, kinase reaction was quenched by adding SDS loading buffer. Proteins were resolved by NuPAGE 4-12\% Bis-Tris protein gels and transferred to a PVDF membrane. Then the membrane was incubated at room temperature for $1 \mathrm{hr}$ in a blocking buffer (TBS with $0.1 \%$ tween 20 and $5 \%$ non-fat dry milk). After that membrane was incubated with Phospho-Btk (Ser180) (3D3) Mouse (Cell Signaling, Cat\# 3537) (1:1000) antibody or BTK rabbit antibody (Cell Signaling, Cat\# 8547) (1:1000). Following overnight incubation at $4{ }^{\circ} \mathrm{C}$, the membrane was washed three times with TBST buffer (TBS with $0.1 \%$ tween 20). After that, the membrane was further incubated with appropriate HRP-conjugated secondary antibodies (Rabbit/ Mouse, Cell Signaling, Cat\#7074/ 7076) for $1 \mathrm{hr}$ at room temperature. After washing the membrane three times with TBST buffer, protein bands were visualized by chemiluminescence (Azure Biosystems C600 imager).

\subsection{Validation of ternary complex (AMPK: PHICS3: BTK) formation in HEK293T cells}

Co-immunoprecipitation was performed to evaluate the ternary complex (AMPK: PHICS3: BTK) formation in HEK293T cells after overexpressing the BTK, which is otherwise absent in these cells. HEK293T cells were cultured in DMEM supplemented with 10\% FBS, penicillin (100 units $/ \mathrm{mL}$ ) and streptomycin $(100 \mu \mathrm{g} / \mathrm{mL})$. Cells were maintained at $37^{\circ} \mathrm{C}$ in $5 \% \mathrm{CO} 2$ humidified atmosphere.

After 36 hrs transfection of pcDNA3.1(+) BTK-Flag plasmid using TransIT®-293 Transfection Reagent, HEK 293T cells were maintained in a serum-free media overnight before incubation with compounds. After that, cells were treated with $5 \mu \mathrm{M}$ concentration of AMPK activator or BTK binder or PHICS3 or DMSO control for $4 \mathrm{hrs}$ in a fresh serum-free media before cells were lysed on ice in a lysis buffer (M-PER ${ }^{\text {TM }}$ Mammalian Protein Extraction Reagent, Halt ${ }^{\mathrm{TM}}$ Protease and Phosphatase Inhibitor Cocktail (2X) and $50 \mathrm{mM} \mathrm{NaF}$ ). Next, the protein concentrations of cell lysates were measured using Pierce ${ }^{\mathrm{TM}}$ BCA Protein Assay Kit. Equal amounts of cell lysates were incubated with Anti-FLAG® M2 Magnetic Beads overnight at $4{ }^{\circ} \mathrm{C}$. Then beads were washed three 
times with TBS buffer ( $50 \mathrm{mM}$ Tris $\mathrm{HCl}, 150 \mathrm{mM} \mathrm{NaCl}, \mathrm{pH}$ 7.4) and eluted the proteins with SDS-loading buffer by heating $5 \mathrm{~min}$ at $95^{\circ} \mathrm{C}$. Eluted proteins were analyzed by western blotting using AMPK- $\alpha$ rabbit antibody (Cell Signaling, Cat\#5832) or Flag mouse antibody (Cell Signaling, Cat\# 8146) (1:2000) or Beta-actin mouse antibody (Cell Signaling, Cat\#3700) (1:2000).

\subsection{Immunoblotting analysis to confirm the BTK phosphorylation in HEK293T cells}

PHICS induced phosphorylation of BTK in cells was confirmed by monitoring the phosphorylation at Ser180 position of BTK. Initially, HEK293T cells were transfected with pcDNA3.1(+) BTK-Flag plasmid using TransIT®293 Transfection Reagent. After 36 hrs of transfection, cells were maintained in a serum-free media overnight before incubation with compounds. After that, cells were treated with $5 \mu \mathrm{M}$ concentration of AMPK activator or PHICS3 or DMSO control for 4 hrs in a fresh serum-free media before cells were lysed on ice in a lysis buffer (M-PER ${ }^{\mathrm{TM}}$ Mammalian Protein Extraction Reagent, Halt ${ }^{\mathrm{TM}}$ Protease and Phosphatase Inhibitor Cocktail (2X) and $50 \mathrm{mM} \mathrm{NaF}$ ). Next, protein concentrations of cell lysates were measured using Pierce ${ }^{\mathrm{TM}}$ BCA Protein Assay Kit. An equal amount of cell lysates were resolved using NuPAGE 4-12\% Bis-Tris protein gels and transferred to a PVDF membrane. Then the membrane was incubated at room temperature for $1 \mathrm{hr}$ in a blocking buffer (TBS with $0.1 \%$ tween 20 and $5 \%$ non-fat dry milk). After that membrane was incubated with Phospho-Btk (Ser180) (3D3) Mouse (Cell Signaling, Cat\# 3537) (1:1000) primary antibody. Flag mouse antibody (Cell Signaling, Cat\# 8146) (1:2000) or Beta-actin mouse antibody (Cell Signaling, Cat\#3700) (1:2000) was incubated with the membrane after blocking with buffer (TBS with $0.1 \%$ tween 20 and $5 \%$ BSA). Following overnight incubation at $4{ }^{\circ} \mathrm{C}$, the membrane was washed three times with TBST buffer (TBS with $0.1 \%$ tween 20). After that, the membrane was further incubated with appropriate HRP-conjugated secondary antibodies (Rabbit/ Mouse, Cell Signaling, Cat\#7074/ 7076) for $1 \mathrm{hr}$ at room temperature. After washing the membrane three times with TBST buffer, protein bands were visualized by chemiluminescence (Azure Biosystems C600 imager).

A similar protocol was followed to observe the linker length, concentration, and dose dependency of PHICS3 induced phosphorylation in cells. HEK293T cells were maintained in a serum-free media overnight before incubation with the compounds after overexpressing Flag-BTK. In one experiment, $5 \mu \mathrm{M}$ concentration of PHICS3 with different linkers ( $n=6, n=8$, and PEG2) was incubated for 4 hrs. In another experiment, different concentrations $(0.1,0.5,1,5$, and $10 \mu \mathrm{M})$ of PHICS3 were incubated for 4 hrs and $5 \mu \mathrm{M}$ of PHICS 3 was incubated 
with HEK293T cells for different time points (1, 2, 4 and $5 \mathrm{hrs)}$ before lysis. Then western blotting was performed with Phospho-Btk (Ser180) (3D3) antibody (Cell Signaling, Cat\#3537) (1:1000) and Flag mouse antibody (Cell Signaling, Cat\#8146) (1:2000). To further validate that the AMPK activation alone is not responsible to induce significant Ser180 phosphorylation in cells, different concentrations $(5,10$ and $20 \mu \mathrm{M})$ of a potent commercially available AMPK activator (PF-06409577) or $5 \mu \mathrm{M}$ of PHICS3 or $5 \mu \mathrm{M}$ of AMPK activator or DMSO control was incubated with HEK293T cells for 4 hrs before lysis of the cells and western blotting was performed using phospho-Btk (Ser180) (3D3) antibody and Flag mouse antibody.

Next, we confirmed the target engagement of PHICS3 in cells through a competition experiment in the presence of Ibrutinib as well as using a chemically modified PHICS3 (Piv-PHICS3). HEK293T cells were maintained in a serum-free media overnight before incubation of the compounds after overexpressing Flag-BTK. Then, cells were treated with $5 \mu \mathrm{M}$ concentration of PHICS3 or Piv-PHICS3 for 4 hrs before cell lysis and western blotting was performed using phospho-Btk (Ser180) (3D3) antibody and Flag mouse antibody. In the competition experiment, HEK293T cells were incubated with DMSO or AMPK activator $(5 \mu \mathrm{M})$ or PHICS3 $(5 \mu \mathrm{M})$ or PHICS3 $(5 \mu \mathrm{M})+$ Ibrutinib $(1 \mu \mathrm{M})$ or Ibrutinib $(1 \mu \mathrm{M})$ for $4 \mathrm{hrs}$ in serum-free media. In this experiment, Ibrutinib was treated $1 \mathrm{hr}$ before the addition of PHICS3 molecule. After cell lysis, western blotting was performed using phospho-Btk (Ser180) (3D3) antibody and Flag mouse antibody.

\subsection{Confirmation of the phosphorylation site of BTK and target engagement of PHICS3 by mutational} studies

S180A mutation was performed to confirm the PHICS3 induced phosphorylation site in HEK293T cells. Additionally, since the reversible analog of Ibrutinib is an ATP competitive inhibitor of BTK, several mutations were performed in the ATP binding pocket of BTK to validate the target engagement of PHICS3. These mutant constructs were prepared using Q5® Site-Directed Mutagenesis Kit with following primers: BTK S180A (forward: 5'-ACCTGGGAGTGCTCACCGGA-3', reverse: 5'-TTTAAGCTTCCATTCCTGTTCTCC-3') K430R (forward: 5'CGTGGCCATCAGGATGATCAAAG-3'， reverse: 5'-TCGTACTGGCCTCTCCAT-3') T474A (forward: 5'CTTCATCATCGCTGAGTACATGGCCAATG-3', reverse: 5'-ATGGGGCGCTGCTTGGTG-3') D539N (forward: 5'-TAAAGTATCTAATTTCGGCCTGTC-3', reverse: 5'-ACAACTCCTTGATCGTTTAC-3'). The entire open reading frame (ORF) of all prepared plasmids was confirmed by DNA sequencing. 
Next, HEK293T cells were transfected with wild-type (WT) or mutant BTK-Flag plasmids using TransIT®-293 Transfection Reagent. After 36 hrs of transfection, cells were maintained in serum-free media overnight before incubation with compounds. After that, cells were treated with $5 \mu \mathrm{M}$ concentration of AMPK activator or PHICS3 or DMSO control for $4 \mathrm{hrs}$ in a fresh serum-free media before cells were lysed on ice in a lysis buffer (M-PER ${ }^{\mathrm{TM}}$ Mammalian Protein Extraction Reagent, Halt ${ }^{\mathrm{TM}}$ Protease and Phosphatase Inhibitor Cocktail (2X) and $50 \mathrm{mM}$ $\mathrm{NaF}$ ). Then, western blotting was performed with Phospho-Btk (Ser180) (3D3) antibody (Cell Signaling, Cat\#3537) (1:1000) and Flag mouse antibody (Cell Signaling, Cat\#8146) (1:2000).

\subsection{Synthesis of PHICS1 and its analogs}

(+)-JQ1 PA was purchased from MedChemExpress and (-)-JQ1 PA, the inactive analogue, was synthesized according to literature ${ }^{4}$. Compounds 5-9 were either purchased or synthesized via amide coupling with the precursor azido acid and N-hydroxysuccinimide, washed with water, then used without further purification for the next step 5 .

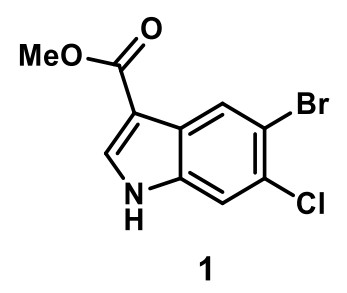

\section{Synthesis of methyl 5-bromo-6-chloro-1H-indole-3-carboxylate (1)}

Following a literature procedure, 5-bromo-6-chloro- $1 \mathrm{H}$-indole $(2.22 \mathrm{~g}, 0.63 \mathrm{mmol})$ was dissolved in $50 \mathrm{~mL}$ of DMF and cooled to $0^{\circ} \mathrm{C}$ in an ice bath. Trifluoroacetic acid anhydride $(5.4 \mathrm{~mL}, 38.5 \mathrm{mmol})$ was added slowly to this solution while stirring. After 1 hour, the reaction was quenched with saturated $\mathrm{Na}_{2} \mathrm{CO}_{3}(\mathrm{aq})$ and a tan precipitate was filtered and collected. This crude precipitate was directly treated with $3 \mathrm{M} \mathrm{NaOH}(\mathrm{aq})$ and refluxed overnight to form the carboxylic acid. Then, the reaction was acidified to a pH of 1-2, extracted with EtOAc (100 $\mathrm{mL} \times 3$ ), dried over $\mathrm{Na}_{2} \mathrm{SO}_{4}$, and evaporated to dryness under reduced pressure. The crude solid was refluxed in $50 \mathrm{~mL} \mathrm{MeOH}$ and $1 \mathrm{~mL}$ of conc. $\mathrm{H}_{2} \mathrm{SO}_{4}$ to afford the methyl ester as a reddish solid $(2.00 \mathrm{~g}, 72 \%$ yield). The data matches literature reports ${ }^{6}$. 


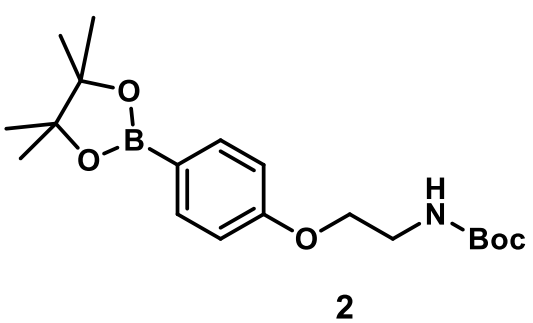

\section{Synthesis of $\mathrm{N}$-Boc-((4-aminoethoxy)phenyl)boronic acid pinacol ester (2)}

Following a literature procedure, 4-hydroxyphenyl boronic acid $(2.00 \mathrm{~g}, 9.09 \mathrm{mmol}), 2$-(Boc-amino)ethylbromide (2.04 g, $9.09 \mathrm{mmol})$, and oven-dried $\mathrm{K}_{2} \mathrm{CO}_{3}(3.77 \mathrm{~g}, 27.26 \mathrm{mmol})$ was added to $40 \mathrm{~mL} \mathrm{DMF}$ and the resulting suspension was heated at $60^{\circ} \mathrm{C}$ overnight. Then, water was added to the reaction mixture and the aqueous layer extracted with EtOAc (100 mL x 3). After drying over $\mathrm{Na}_{2} \mathrm{SO}_{4}$ and concentrating under reduced pressure, the crude oil was purified by silica gel column chromatography ( $4: 1$ hexanes:EtOAc) to afford a colorless oil (3.04 g, $92 \%$ yield). The data matches literature reports ${ }^{6}$.

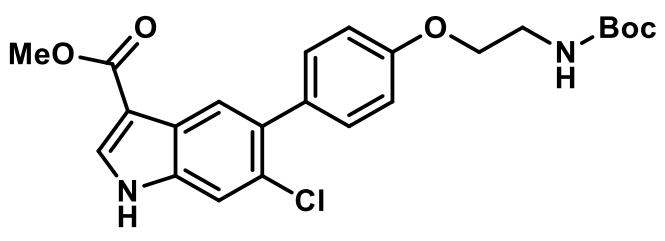

3

\section{Synthesis of methyl 5-(4-(2-((N-Boc)amino)ethoxy)phenyl)-6-chloro-1H-indole-3-carboxylate (3)}

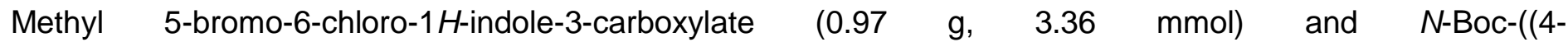
aminoethoxy)phenyl)boronic acid pinacol ester $(1.22 \mathrm{~g}, 3.36 \mathrm{mmol})$ were suspended in $67 \mathrm{~mL}$ toluene. Potassium carbonate $(3.02 \mathrm{~g}, 21.85 \mathrm{mmol})$ was dissolved in $33 \mathrm{~mL}$ deionized water and added to the toluene mixture, then $\mathrm{Pd}(\mathrm{dppf}) \mathrm{Cl}_{2} \cdot \mathrm{DCM}(0.247 \mathrm{~g}, 0.303 \mathrm{mmol})$ was added. The reaction mixture was quickly degassed then refluxed for 2 hours. Then, the reaction was concentrated under reduced pressure, redissolved in ethyl acetate, filtered through a pad of celite, washed with water and brine, then dried with $\mathrm{Na}_{2} \mathrm{SO}_{4}$ and concentrated. The residue was purified by silica gel column chromatography (1:1 hexanes:EtOAc) to afford a white solid (1.40

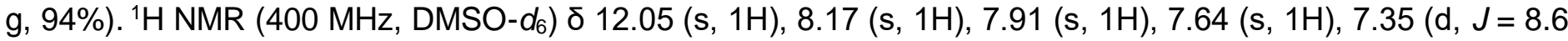
Hz, 2H), $7.02(\mathrm{~d}, J=8.7 \mathrm{~Hz}, 2 \mathrm{H}), 4.03(\mathrm{t}, J=5.9 \mathrm{~Hz}, 2 \mathrm{H}), 3.80$ (s, 3H), 3.34 (t, $J=5.8 \mathrm{~Hz}, 2 \mathrm{H}) 1.40(\mathrm{~s}, 9 \mathrm{H})$. 


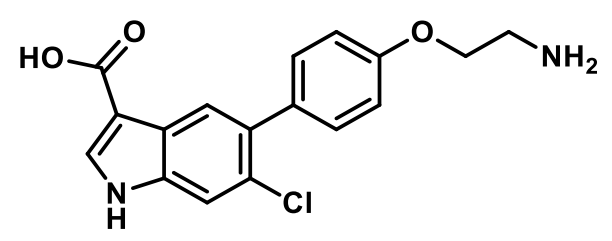

4

\section{Synthesis of 5-(4-(2-aminoethoxy)phenyl)-6-chloro-1H-indole-3-carboxylic acid (4)}

Methyl 5-(4-(2-((N-Boc)amino)ethoxy)phenyl)-6-chloro-1H-indole-3-carboxylate $(1.40 \mathrm{~g}, 3.17 \mathrm{mmol})$ was first hydrolyzed into the corresponding carboxylic acid by treatment with 3 eq $1 \mathrm{M} \mathrm{NaOH}$ and microwaved for 2 hours at $100^{\circ} \mathrm{C}$ as a 1:1:1 THF:MeOH:water solution. Then, the solution was concentrated under reduced pressure, the aqueous layer acidified to $\mathrm{pH}=3-4$, and extracted $3 \times$ with EtOAc. The combined organic layers were dried with $\mathrm{Na}_{2} \mathrm{SO}_{4}$, filtered, and concentrated to a white residue that is taken to the next step without further purification. TFA ( $8 \mathrm{~mL}$ ) as a $50 \%$ solution in DCM was slowly added to the white solid dissolved in $25 \mathrm{~mL} \mathrm{DCM}$ at $0^{\circ} \mathrm{C}$. The reaction was stirred at room temperature for 2 hours then concentrated under reduced pressure to afford a redpurple oil. The oil was treated with multiple $20 \mathrm{~mL}$ aliquots of ether and evaporated and dried under high vacuum to afford a reddish tan solid $(0.94 \mathrm{~g}, 90 \%) .{ }^{1} \mathrm{H}$ NMR $(400 \mathrm{MHz}$, DMSO-d $) \delta 11.99(\mathrm{~s}, 1 \mathrm{H}), 8.08(\mathrm{~s}, 1 \mathrm{H}), 7.93(\mathrm{~s}$, 1H), $7.63(\mathrm{~s}, 1 \mathrm{H}), 7.39$ (d, $J=8.7 \mathrm{~Hz}, 2 \mathrm{H}), 7.07$ (d, $J=8.7 \mathrm{~Hz}, 2 \mathrm{H}), 4.22(\mathrm{t}, J=5.1 \mathrm{~Hz}, 2 \mathrm{H}), 3.26(\mathrm{t}, J=5.1 \mathrm{~Hz}$, 2H). ${ }^{13} \mathrm{C}$ NMR (101 MHz, DMSO-d $\left.d_{6}\right) \delta$ 165.6, 157.1, 136.0, 133.9, 133.1, 132.7, 130.9, 125.8, 125.3, 122.7, 114.2, 112.9, 107.6, 64.5.

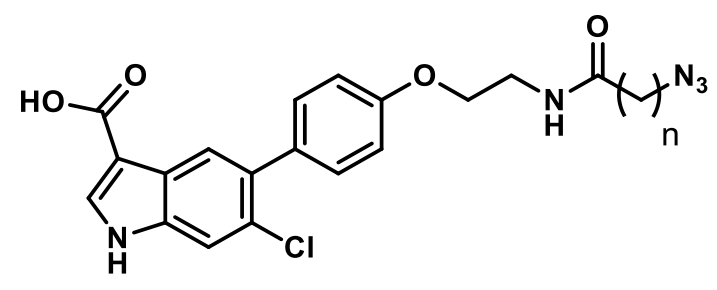

10-14 $n=3,5,7,9,11$

\section{Synthesis of 5-(4-(2-aminoethoxy)phenyl)-6-chloro-1H-indole-3-acyl azides (10-14)}

The following general method was used to prepare the azides of varying linker lengths: Compound 5-9 (0.22 mmol, 1 eq) was added to a solution of $4(0.20 \mathrm{mmol}, 0.9 \mathrm{mmol})$ in DMF $(0.1 \mathrm{M})$. DIPEA was added under nitrogen ( 2 eq) and the solution was stirred for 2 hours at room temperature under nitrogen then concentrated 
under reduced pressure. The residue was purified by silica gel column chromatography (1:10 MeOH:DCM) to afford 10-14 as white powder.

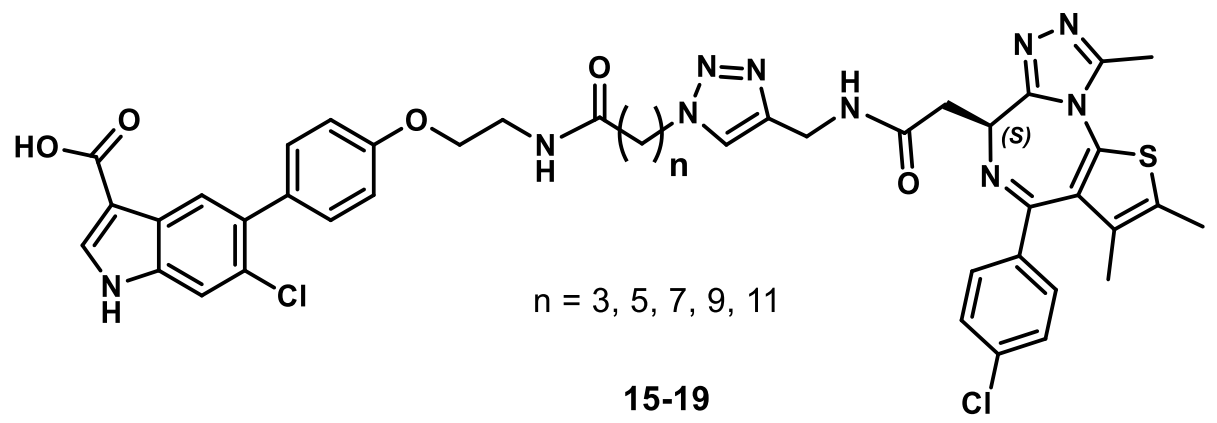

\section{Synthesis of 15-19}

The following general method was used to prepare the AMPK PHICS problems of varying linker lengths: compound 10-14 (0.037 mmol, $1 \mathrm{eq}),(+)$ or (-)-JQ1-PA (0.041 mmol, $1.1 \mathrm{eq})$ was dissolved in THF (0.05 M). To this solution was added $0.5 \mathrm{M} \mathrm{CuSO}_{4}(0.2 \mathrm{eq}), 0.5 \mathrm{M}$ sodium ascorbate (0.2 eq), and $0.5 \mathrm{M} \mathrm{TBTA}(0.2$ eq). Upon completion (5 minutes to an hour), the solution turns from brown to blue and directly purified by silica gel column chromatography (1:10 MeOH:DCM) or HPLC to afford $15(n=3), 16$ (PHICS1, $n=5), 17(n=7), 18(n=9), 19$ $(\mathrm{n}=11)$, and $(\boldsymbol{R})-\mathbf{1 6}$ (iPHICS1 $\mathrm{n}=5$, from inactive $(-)$-JQ1) as light beige solids.

Characterization data for 15: ${ }^{1} \mathrm{H}$ NMR (400 MHz, DMSO- $\left.d_{6}\right) \delta 11.93(\mathrm{br}), 11.42(\mathrm{~s}), 8.71(\mathrm{t}, \mathrm{J}=5.7 \mathrm{~Hz}, 1 \mathrm{H})$, $8.17(\mathrm{t}, J=5.6 \mathrm{~Hz}, 1 \mathrm{H}), 8.07(\mathrm{~s}, 1 \mathrm{H}), 7.94(\mathrm{~d}, J=10.7 \mathrm{~Hz}, 2 \mathrm{H}), 7.62(\mathrm{~s}, 1 \mathrm{H}), 7.47(\mathrm{~d}, J=8.4 \mathrm{~Hz}, 2 \mathrm{H}), 7.39(\mathrm{~d}, J$ $=8.4 \mathrm{~Hz}, 2 \mathrm{H}), 7.34(\mathrm{~d}, J=8.5 \mathrm{~Hz}, 2 \mathrm{H}), 7.02(\mathrm{~d}, J=8.7 \mathrm{~Hz}, 2 \mathrm{H}), 4.53(\mathrm{~m}, J=7.1 \mathrm{~Hz}, 1 \mathrm{H}), 4.38-4.32(\mathrm{~m}, 4 \mathrm{H})$, 4.05 (t, J=5.8 Hz, 2H), $3.47(\mathrm{q}, J=5.7 \mathrm{~Hz}, 2 \mathrm{H}), 2.60(\mathrm{~s}, 3 \mathrm{H}), 2.40(\mathrm{~s}, 3 \mathrm{H}), 2.15$ (t, $J=7.3 \mathrm{~Hz}, 2 \mathrm{H}), 2.05(\mathrm{q}, J=$

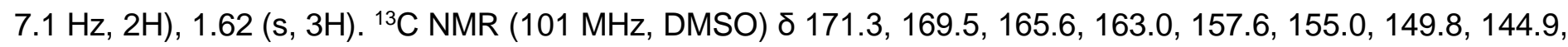
136.7, 135.9, 135.2, 133.8, 133.7, 132.8, 132.5, 132.2, 130.8, 130.6, 130.2, 129.9, 129.5, 128.4, 125.8, 125.2, $122.8,122.7,114.0,112.8,66.3,53.9,48.9,38.3,37.5,31.9,25.9,14.0,12.7,11.3$.

Characterization data for 16 (PHICS1): ${ }^{1} \mathrm{H}$ NMR (400 MHz, DMSO-d $) \delta 12.19-12.00(\mathrm{br}, 1 \mathrm{H}), 11.92(\mathrm{~s}, 1 \mathrm{H})$, $8.71(\mathrm{t}, J=5.7 \mathrm{~Hz}, 1 \mathrm{H}), 8.05(\mathrm{~s}, 2 \mathrm{H}), 7.93(\mathrm{~s}, 2 \mathrm{H}), 7.61(\mathrm{~s}, 1 \mathrm{H}), 7.45(\mathrm{~d}, J=8.6 \mathrm{~Hz}, 2 \mathrm{H}), 7.38(\mathrm{~d}, J=8.6 \mathrm{~Hz}, 2 \mathrm{H})$, $7.34(\mathrm{~d}, J=8.6 \mathrm{~Hz}, 2 \mathrm{H}), 7.01(\mathrm{~d}, J=8.7 \mathrm{~Hz}, 2 \mathrm{H}), 4.52(\mathrm{~m}, J=7.1 \mathrm{~Hz}, 1 \mathrm{H}), 4.35(\mathrm{~d}, J=5.6 \mathrm{~Hz}, 2 \mathrm{H}), 4.28(\mathrm{t}, J=$ $7.2 \mathrm{~Hz}, 2 \mathrm{H}), 4.06-4.00(\mathrm{~m}, 2 \mathrm{H}), 3.44(\mathrm{q}, J=5.6 \mathrm{~Hz}, 2 \mathrm{H}), 3.27(\mathrm{dd}, 2 \mathrm{H}), 2.59(\mathrm{~s}, 3 \mathrm{H}), 2.39(\mathrm{~s}, 3 \mathrm{H}), 2.09(\mathrm{t}, J=$ $7.4 \mathrm{~Hz}, 2 \mathrm{H}), 1.78(\mathrm{p}, J=7.3 \mathrm{~Hz}, 2 \mathrm{H}), 1.61(\mathrm{~s}, 3 \mathrm{H}), 1.52(\mathrm{p}, J=7.5 \mathrm{~Hz}, 2 \mathrm{H}), 1.29-1.18(\mathrm{~m}, 2 \mathrm{H}) .{ }^{13} \mathrm{C} \mathrm{NMR}(101$ $\left.\mathrm{MHz}, \mathrm{DMSO}-d_{6}\right) \delta 172.3,169.5,165.6,163.0,157.6,155.1,149.8,144.9,136.7,135.9,135.2,133.7,133.7$, 
132.7, 132.5, 132.3, 130.8, 130.7, 130.2, 129.8, 129.5, 128.4, 125.8, 125.3, 122.7, 122.7, 114.0, 112.8, 66.4, $53.9,49.1,38.2,37.5,35.0,34.3,29.5,25.5,24.6,14.0,12.7,11.3$.

Characterization data for (R)-16 (iPHICS1): The NMR data matches 16.

Characterization data for 17: ${ }^{1} \mathrm{H}$ NMR $\left(400 \mathrm{MHz}\right.$, DMSO- $\left.d_{6}\right) \delta 11.93(\mathrm{~s}, 1 \mathrm{H}), 8.72(\mathrm{t}, J=5.7 \mathrm{~Hz}, 1 \mathrm{H}), 8.06(\mathrm{~s}$, 2H), $7.93(\mathrm{~d}, J=6.8 \mathrm{~Hz}, 2 \mathrm{H}), 7.61(\mathrm{~s}, 1 \mathrm{H}), 7.45(\mathrm{dd}, J=8.6,1.6 \mathrm{~Hz}, 2 \mathrm{H}), 7.41-7.31(\mathrm{~m}, 4 \mathrm{H}), 7.01(\mathrm{~d}, J=7.8$ $\mathrm{Hz}, 2 \mathrm{H}), 4.52(\mathrm{~m}, J=7.2 \mathrm{~Hz}, 1 \mathrm{H}), 4.35(\mathrm{~d}, J=5.6 \mathrm{~Hz}, 2 \mathrm{H}), 4.27$ (t, $J=7.2 \mathrm{~Hz}, 2 \mathrm{H}), 4.03$ (s, 2H), 3.44 (d, $J=5.7$ $\mathrm{Hz}, 2 \mathrm{H}), 3.29-3.22(\mathrm{~m}, 2 \mathrm{H}), 2.59(\mathrm{~s}, 3 \mathrm{H}), 2.40(\mathrm{~s}, 3 \mathrm{H}), 2.09(\mathrm{t}, J=7.1 \mathrm{~Hz}, 2 \mathrm{H}), 1.61(\mathrm{~s}, 3 \mathrm{H}), 1.49$ (q, J = $7.5 \mathrm{~Hz}$,

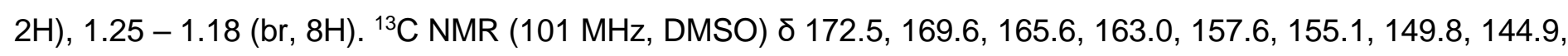
$136.7,135.9,135.2,133.8,133.8,132.8,132.5,132.3,130.8,130.7,130.2,129.8,129.5,128.4,125.8,125.3$, 122.7, 122.7, 114.0, 112.9, 66.4, 53.9, 50.6, 49.2, 38.2, 37.5, 35.2, 34.3, 29.7, 28.4, 28.1, 25.7, 14.1, 12.7, 11.3.

Characterization data for 18: ${ }^{1} \mathrm{H}$ NMR $\left(400 \mathrm{MHz}\right.$, DMSO- $\left.d_{6}\right) \delta 11.92(\mathrm{~s}, 1 \mathrm{H}), 8.72(\mathrm{t}, J=5.7 \mathrm{~Hz}, 1 \mathrm{H}), 8.05$ (d, $J=7.6 \mathrm{~Hz}, 2 \mathrm{H}), 7.92(\mathrm{~d}, J=8.4 \mathrm{~Hz}, 2 \mathrm{H}), 7.61(\mathrm{~s}, 1 \mathrm{H}), 7.45(\mathrm{~d}, J=8.3 \mathrm{~Hz}, 2 \mathrm{H}), 7.35(\mathrm{dd}, J=11.0,8.4 \mathrm{~Hz}, 4 \mathrm{H})$, $7.01(\mathrm{~d}, J=8.5 \mathrm{~Hz}, 2 \mathrm{H}), 4.52(\mathrm{~m}, J=8.1,6.2 \mathrm{~Hz}, 1 \mathrm{H}), 4.35(\mathrm{t}, J=5.8 \mathrm{~Hz}, 2 \mathrm{H}), 4.26(\mathrm{t}, J=7.2 \mathrm{~Hz}, 2 \mathrm{H}), 4.03(\mathrm{t}, J$ $=5.6 \mathrm{~Hz}, 2 \mathrm{H}), 3.44(\mathrm{q}, J=5.6 \mathrm{~Hz}, 2 \mathrm{H}), 3.28-3.20(\mathrm{~m}, 2 \mathrm{H}), 2.59(\mathrm{~s}, 3 \mathrm{H}), 2.40(\mathrm{~s}, 3 \mathrm{H}), 2.10-2.06(\mathrm{~m}, 2 \mathrm{H}), 1.61$ (s, 3H), $1.51-1.46(\mathrm{~m}, 2 \mathrm{H}), 1.21$ (s, 12H). ${ }^{13} \mathrm{C}$ NMR (101 MHz, DMSO) $\delta$ 172.7, 169.6, 165.6, 163.0, 157.6, $155.1,149.8,144.9,136.7,135.9,135.2,133.8,133.7,132.8,132.5,132.3,130.7,130.7,130.2,129.8,129.5$, $128.4,125.8,125.2,122.7,114.0,112.8,107.6,66.4,53.9,49.3,38.2,37.5,35.3,34.3,29.7,28.7,28.6,28.4$, 25.8, 25.2, 25.1, 14.1, 12.7, 11.3 .

Characterization data for 19: ${ }^{1} \mathrm{H}$ NMR $\left(400 \mathrm{MHz}\right.$, DMSO- $\left.d_{6}\right) \delta 11.92(\mathrm{~s}, 1 \mathrm{H}), 8.72$ (t, $\left.J=5.7 \mathrm{~Hz}, 1 \mathrm{H}\right), 8.05$ (d, $J=7.6 \mathrm{~Hz}, 2 \mathrm{H}), 7.92(\mathrm{~d}, J=8.4 \mathrm{~Hz}, 2 \mathrm{H}), 7.61(\mathrm{~s}, 1 \mathrm{H}), 7.45(\mathrm{~d}, J=8.3 \mathrm{~Hz}, 2 \mathrm{H}), 7.35(\mathrm{dd}, J=11.0,8.4 \mathrm{~Hz}, 4 \mathrm{H})$, $7.01(\mathrm{~d}, J=8.5 \mathrm{~Hz}, 2 \mathrm{H}), 4.52(\mathrm{~m}, J=8.1,6.2 \mathrm{~Hz}, 1 \mathrm{H}), 4.35(\mathrm{t}, J=5.8 \mathrm{~Hz}, 2 \mathrm{H}), 4.26(\mathrm{t}, J=7.2 \mathrm{~Hz}, 2 \mathrm{H}), 4.03(\mathrm{t}, J$ $=5.6 \mathrm{~Hz}, 2 \mathrm{H}), 3.44(\mathrm{q}, J=5.6 \mathrm{~Hz}, 2 \mathrm{H}), 3.28-3.20(\mathrm{~m}, 2 \mathrm{H}), 2.59(\mathrm{~s}, 3 \mathrm{H}), 2.40(\mathrm{~s}, 3 \mathrm{H}), 2.10-2.06(\mathrm{~m}, 2 \mathrm{H}), 1.61$ (s, 3H), $1.51-1.46(\mathrm{~m}, 2 \mathrm{H}), 1.21$ (s, 12H). ${ }^{13} \mathrm{C}$ NMR (101 MHz, DMSO) $\delta 172.95,170.03,163.48,158.12$, $137.17,136.38,135.66,134.32,133.24,132.94,132.77,131.21,131.14,130.65,130.28,129.99,128.87$, $126.27,125.70,123.14,114.50,113.33,66.90,54.38,49.73,38.68,38.01,35.78,34.75,30.21,29.39,29.36$, 29.30, 29.27, 29.10, 28.86, 26.34, 25.73, 14.52, 13.13, 11.78 . 


\subsection{Synthesis of PHICS2 and its analogs}

Methyl (S)-(1-hydroxy-3-(4-hydroxy-2-nitrophenyl)propan-2-yl)carbamate (20) was synthesized according to reported procedure. ${ }^{7}$

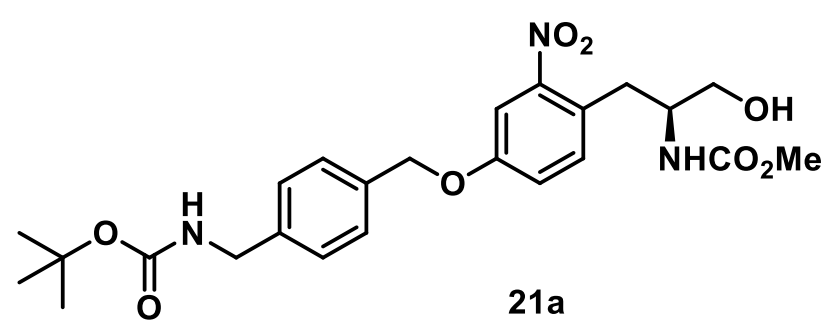

Synthesis of methyl (S)-(1-(4-((4-(((tert-butoxycarbonyl)amino)methyl)benzyl)oxy)-2-nitrophenyl)-3hydroxypropan-2-yl)carbamate (21a)

To a solution of $20(1.2 \mathrm{~g}, 4.4 \mathrm{mmol})$ and $\mathrm{K}_{2} \mathrm{CO}_{3}(1.2 \mathrm{~g}, 8.7 \mathrm{mmol})$ in $33 \mathrm{~mL}$ of DMF was added tert-butyl (4(bromomethyl)benzyl)carbamate $(1.4 \mathrm{~g}, 4.7 \mathrm{mmol})$ in $3 \mathrm{~mL}$ DMF in a dropwise manner. The reaction mixture was heated at $50^{\circ} \mathrm{C}$ overnight and progress of the reaction was monitored by LCMS. When signal of starting material VS-3 disappeared, solvent was removed under reduced pressure. The solid residue was partitioned between $220 \mathrm{~mL}$ of ethyl acetate and $40 \mathrm{~mL}$ of water. The organic layer was washed with brine, dried over $\mathrm{Na}_{2} \mathrm{SO}_{4}, \mathrm{and}$ concentrated under reduced pressure. The crude product was purified by silica gel column chromatography (gradient from 20:80 ethyl acetate/petroleum ether as eluent up to 50:50/petroleum ether) to provide $1.5 \mathrm{~g}$ (70\%) of desired product 21a as a yellow solid. ${ }^{1} \mathrm{H}$ NMR $\left(400 \mathrm{MHz}, \mathrm{CDCl}_{3}\right): \delta 7.50(\mathrm{~s}, 1 \mathrm{H}), 7.38-7.36(\mathrm{~m}, 2 \mathrm{H}), 7.31-$ $7.29(\mathrm{~m}, 2 \mathrm{H}), 7.15-7.12(\mathrm{~m}, 1 \mathrm{H}), 5.32(\mathrm{br} \mathrm{s}, 1 \mathrm{H}), 5.06(\mathrm{~s}, 2 \mathrm{H}), 4.92(\mathrm{br} \mathrm{s}, 1 \mathrm{H}), 4.31(\mathrm{~s}, 2 \mathrm{H}), 3.96(\mathrm{~s}, 1 \mathrm{H}), 3.73-$ $3.62(\mathrm{~m}, 2 \mathrm{H}), 3.57(\mathrm{~s}, 3 \mathrm{H}), 3.14-3.11(\mathrm{~m}, 1 \mathrm{H}), 2.99-2.95(\mathrm{~m}, 1 \mathrm{H}), 2.39(\mathrm{br} \mathrm{s}, 1 \mathrm{H}), 1.45 \mathrm{ppm}(\mathrm{s}, 9 \mathrm{H}) ;{ }^{13} \mathrm{C} \mathrm{NMR}$ $\left(101 \mathrm{MHz}, \mathrm{CDCl}_{3}\right) \delta 157.8,157.2,156.1,150.2,139.4,134.9,133,7,128.0,127.9,125.5,120.7,110.6,79.81$, 70.43, 64.58, 54.32, 52.31, 33.46, 28.52 ppm. LS-MS $[\mathrm{M}+\mathrm{Na}]=512$. 


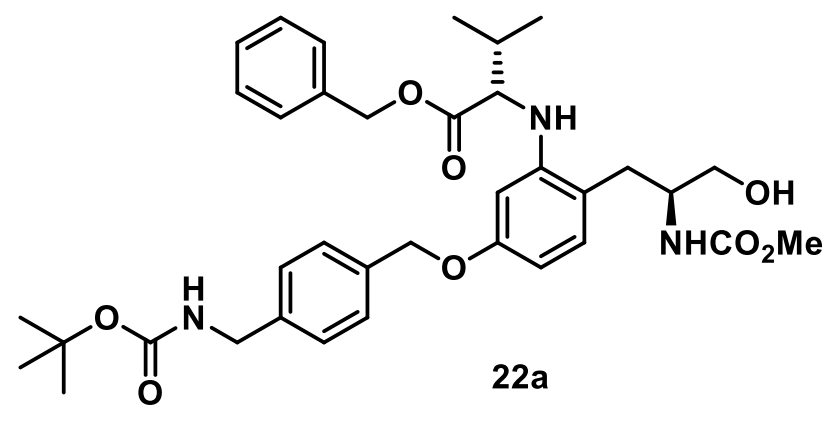

Synthesis of benzyl (5-((4-(((tert-butoxycarbonyl)amino)methyl)benzyl)oxy)-2-((S)-3-hydroxy-2((methoxycarbonyl)amino)propyl)phenyl)-D-valinate (22a)

Step 1. To the solution of $21 \mathrm{a}(1.5 \mathrm{~g}, 3.1 \mathrm{mmol})$ in $\mathrm{MeOH}(52 \mathrm{~mL})$ saturated solution of $\mathrm{Cu}$ (II) acetate $(17 \mathrm{~mL})$ was added. The resulting solution was cooled with ice-water while $\mathrm{NaBH}_{4}(1.8 \mathrm{~g}, 47.4 \mathrm{mmol})$ was added in portions over 1 hour. The progress of the reaction was monitored via LCMS (if the reaction did not reach completion more $\mathrm{NaBH} 4$ should be added). When nitro group was completely reduced, reaction mixture was passed through a short column of silica gel. The filtrate was concentrated under reduced pressure and solid residue was partitioned between $180 \mathrm{~mL}$ EtOAc and $35 \mathrm{~mL}$ of water. The organic layer was washed with brine, dried over $\mathrm{Na}_{2} \mathrm{SO}_{4}$, and concentrated to provide the crude aniline, which was used in the next step without additional purification.

Step 2: To the product from previous step $1.1 \mathrm{~g}$ of benzyl (R)-3-methyl-2(((trifluoromethyl)sulfonyl)oxy)butanoate was added. Mixture was degassed, dissolved in $35 \mathrm{~mL}$ of dichloroethane under nitrogen atmosphere, treated with $600 \mu \mathrm{L}$ of 2,6-luthidine and stirred at $70^{\circ} \mathrm{C}$. Reaction progress was monitored via LCMS and when starting materials were completely consumed ( 72 hours), solvent was removed under reduced pressure and crude mixture purified by silica gel column chromatography (gradient from 10:90 ethyl acetate/petroleum ether as an eluent up to 70:30 ethyl acetate/petroleum ether). $970 \mathrm{mg}(48 \%)$ of desired product 22a as a white solid was obtained. ${ }^{1} \mathrm{H} N M R\left(400 \mathrm{MHz}, \mathrm{CDCl}_{3}\right): \delta 7.32(\mathrm{~d}, J=8.0 \mathrm{~Hz}, 2 \mathrm{H})$, 7.26-7.23 (m, 7H), $6.97(\mathrm{~d}, J=8.4 \mathrm{~Hz}, 1 \mathrm{H}), 6.30(\mathrm{~d}, J=8.4 \mathrm{~Hz}, 1 \mathrm{H}), 6.22(\mathrm{~s}, 1 \mathrm{H}), 5.34(\mathrm{~d}, J=8.0 \mathrm{~Hz}, 1 \mathrm{H}), 5.10$ (s, 2H), 4.90-4.83 (m, 3H), $4.29(\mathrm{~d}, J=5.6 \mathrm{~Hz}, 2 \mathrm{H}), 3.85(\mathrm{~d}, J=5.6 \mathrm{~Hz}, 1 \mathrm{H}), 3.74(\mathrm{br} \mathrm{s}, 1 \mathrm{H}), 3.65(\mathrm{~s}, 3 \mathrm{H}), 3.52$ (d, $J=12.8 \mathrm{~Hz}, 1 \mathrm{H}), 3.44(\mathrm{~d}, J=14.4 \mathrm{~Hz}, 1 \mathrm{H}), 2.82-2.78(\mathrm{~m}, 1 \mathrm{H}), 2.72-2.66(\mathrm{~m}, 1 \mathrm{H}), 2.15-2.10(\mathrm{~m}, 1 \mathrm{H}), 1.44$ (s, 9H), $1.03(\mathrm{~d}, J=6.4 \mathrm{~Hz}, 3 \mathrm{H}), 0.98 \mathrm{ppm}(\mathrm{d}, J=6.8 \mathrm{~Hz}, 3 \mathrm{H}) ;{ }^{13} \mathrm{C} \mathrm{NMR}\left(101 \mathrm{MHz}, \mathrm{CDCl}_{3}\right) \delta 174.7,159.0,157.0$, 
156.0, 146.4, 138.7, 136.5, 135.4, 132.1, 128.7, 128.6, 127.9, 127.8, 116.2, 103.9, 99.2, 79.7, 69.7, 67.1, 62.6, $61.8,53.4,52.2,44.6,31.7,28.5,19.4,19.2$ ppm. LS-MS $[\mathrm{M}+\mathrm{H}]=651$.

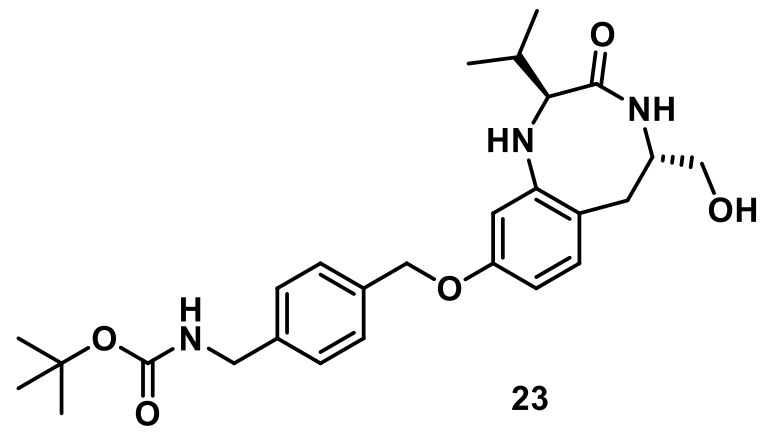

\section{Synthesis of tert-butyl (4-(((2S,5S)-5-(hydroxymethyl)-2-isopropyl-3-oxo-1,2,3,4,5,6-}

\section{hexahydrobenzo[e][1,4]diazocin-9-yl)oxy)methyl)benzyl)carbamate (23)}

A mixture 22 (220 mg, $0.34 \mathrm{mmol}), 5.8 \mathrm{~mL}$ of methanol, and $2.9 \mathrm{~mL}$ of $2 \mathrm{~N} \mathrm{KOH}$ (aqueous) was heated at $70{ }^{\circ} \mathrm{C}$ overnight. Reaction progress was monitored via LCMS. Once reaction was completed, mixture was cooled to room temperature, neutralized with $2 \mathrm{~N} \mathrm{HCl}$ to $\mathrm{pH} 7$ and then concentrated under reduced pressure. The residual solid was dried in vacuo for 1 day before it was dissolved in $34 \mathrm{~mL}$ of DMF. To this solution triethylamine (102 $\mu \mathrm{L})$ and DPPA $(90 \mu \mathrm{L})$ were added at $0^{\circ} \mathrm{C}$. After the stirring was continued for $1 \mathrm{~h}$ at $0{ }^{\circ} \mathrm{C}$ and $17 \mathrm{~h}$ at room temperature, DMF was evaporated under reduced pressure. The residue was partitioned between $200 \mathrm{~mL}$ of ethyl acetate and $35 \mathrm{~mL}$ of water. The organic layer was washed with brine, dried over $\mathrm{Na}_{2} \mathrm{SO}_{4}$, concentrated and purified by silica gel column chromatography (gradient from 20:80 ethyl acetate/petroleum ether as an eluent up to 70:30 ethyl acetate/petroleum ether). $120 \mathrm{mg}(74 \%)$ of desired product 23 as a yellow oil was obtained. ${ }^{1} \mathrm{H}$ NMR (400 MHz, $\left.\mathrm{CDCl}_{3}\right): \delta 7.34(\mathrm{~d}, J=8.0 \mathrm{~Hz}, 2 \mathrm{H}), 7.29-7.26(\mathrm{~m}, 3 \mathrm{H}), 6.84(\mathrm{~d}, J=8.0 \mathrm{~Hz}, 1 \mathrm{H}), 6.75-6.72$ (br s, 1H), $6.46(\mathrm{~d}, J=8.0 \mathrm{~Hz}, 1 \mathrm{H}), 6.42(\mathrm{~s}, 1 \mathrm{H}), 5.01(\mathrm{t}, J=6.0 \mathrm{~Hz}, 1 \mathrm{H}), 4.93(\mathrm{~s}, 2 \mathrm{H}), 4.30(\mathrm{~d}, J=5.6 \mathrm{~Hz}, 1 \mathrm{H}), 3.82$ (d, $J=8.4 \mathrm{~Hz}, 1 \mathrm{H}), 3.70-3.66(\mathrm{~m}, 1 \mathrm{H}), 3.62-3.59(\mathrm{~m}, 1 \mathrm{H}), 3.14-3.07(\mathrm{~m}, 1 \mathrm{H})$, 2.80-2.76 (m, 1H), 2.14-2.02 (m, $1 \mathrm{H}), 1.47(\mathrm{~s}, 9 \mathrm{H}), 1.09$ (d, $J=6.8 \mathrm{~Hz}, 3 \mathrm{H}), 0.96 \mathrm{ppm}(\mathrm{d}, J=6.8 \mathrm{~Hz}, 3 \mathrm{H}) ; \delta^{13} \mathrm{C} \mathrm{NMR}\left(101 \mathrm{MHz}, \mathrm{CDCl}_{3}\right) 175.3$, $158.4,156.1,147.7,138.8,136.2,132.8,127.8,127.7,118.4,108.1,106.7,79.6,69.6,66.8,66.0,55.46,44.4$, $35.4,30.5,28.5,20.3$ and 19.2 ppm. LS-MS $[\mathrm{M}+\mathrm{H}]=485$. 


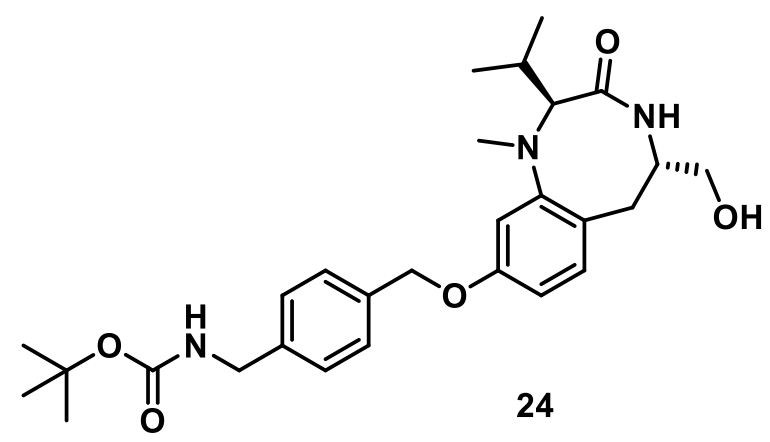

Synthesis of tert-butyl (4-((((2S,5S)-5-(hydroxymethyl)-2-isopropyl-1-methyl-3-0xo-1,2,3,4,5,6hexahydrobenzo[e][1,4]diazocin-9-yl)oxy)methyl)benzyl)carbamate (24)

To a solution of $23(120 \mathrm{mg}, 0.25 \mathrm{mmol})$ in $5 \mathrm{~mL}$ of $\mathrm{CH}_{3} \mathrm{CN}$ were added formaldehyde $(0.2 \mathrm{~mL}, 37 \%$ wt in water), $\mathrm{NaCNBH}_{3}(47 \mathrm{mg})$, and $\mathrm{HOAc}(25 \mu \mathrm{M})$ at $0{ }^{\circ} \mathrm{C}$, sequentially. Reaction progress was monitored via LCMS and when the signal of starting material disappeared (Note: additional portions of formaldehyde, $\mathrm{NaCNBH}_{3}$ and $\mathrm{HOAc}$ might be required to drive the reaction to completion), reaction was partitioned between $50 \mathrm{~mL}$ of ethyl acetate and $10 \mathrm{~mL}$ of water. The organic layer was washed with brine, dried over $\mathrm{Na}_{2} \mathrm{SO}_{4}$, and concentrated under reduced pressure. The residue was purified by silica gel column chromatography (gradient from 10:90 ethyl acetate/petroleum ether as an eluent up to 40:60 ethyl acetate/petroleum ether) to afford $100 \mathrm{mg}(80 \%)$ of the desired product 24. ${ }^{1} \mathrm{H}$ NMR $\left(400 \mathrm{MHz}_{\mathrm{CDCl}}\right): \delta 7.39(\mathrm{~d}, J=8.4 \mathrm{~Hz}, 2 \mathrm{H}), 7.30(\mathrm{~d}, J=8.4 \mathrm{~Hz}, 2 \mathrm{H}), 6.93$ (d, J= $8.4 \mathrm{~Hz}, 1 \mathrm{H}), 6.59(\mathrm{~d}, J=2.8 \mathrm{~Hz}, 1 \mathrm{H}), 6.55(\mathrm{br} \mathrm{s}, 1 \mathrm{H}), 6.48(\mathrm{dd}, J=8.4 \& 2.8 \mathrm{~Hz}, 1 \mathrm{H}), 5.00(\mathrm{~s}, 2 \mathrm{H}), 4.88(\mathrm{br}$, 1H), 4.31 (s, 2H), 3.91 (br s, 1H), $3.69(\mathrm{~d}, J=3.8 \mathrm{~Hz} \& 7.0 \mathrm{~Hz}, 1 \mathrm{H}), 3.52-3.46(\mathrm{~m}, 2 \mathrm{H}), 3.03$ (dd, J=16.8 \& 8.0 $\mathrm{Hz}, 1 \mathrm{H}), 2.75(\mathrm{~s}, 3 \mathrm{H}), 2.45-2.36(\mathrm{~m}, 1 \mathrm{H}), 1.46(\mathrm{~s}, 9 \mathrm{H}), 1.04(\mathrm{~d}, J=6.4 \mathrm{~Hz}, 3 \mathrm{H}), 0.85 \mathrm{ppm}(\mathrm{d}, J=6.8 \mathrm{~Hz}, 3 \mathrm{H})$; ${ }^{13} \mathrm{C}$ NMR $\left(101 \mathrm{MHz}, \mathrm{CDCl}_{3}\right) \delta 174.0,158.7,156.18,156.15,152.9,139.0,136.4,132.6,128.1,127.9,123.7$, 107.3, 107.1, 79.9, 70.1, 66.1, 54.6, 54.5, 36.9, 35.3, 28.7, 28.5, 20.7 and 20.1 ppm. LS-MS [M+Na] = 521.

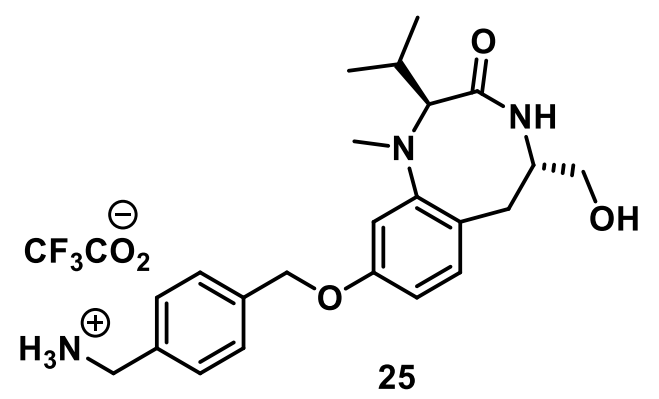


Synthesis of (4-((((2S,5S)-5-(hydroxymethyl)-2-isopropyl-1-methyl-3-oxo-1,2,3,4,5,6-

\section{hexahydrobenzo[e][1,4]diazocin-9-yl)oxy)methyl)phenyl)methanaminium trifluoroacetate (25)}

To an ice-cold solution of $24(12 \mathrm{mg}, 24.0 \mu \mathrm{mol})$ in DCM $(300 \mu \mathrm{L})$ was added $300 \mu \mathrm{L}$ trifluroacetic acid and reaction was allowed to warm up to room temperature and stirred for 30 min. Reaction mixture was concentrated to aford $12.2 \mathrm{mg}(99 \%)$ of crude 25 which was used in the next step immediately. ${ }^{1} \mathrm{H} \mathrm{NMR}\left(400 \mathrm{MHz}, \mathrm{CD}_{3} \mathrm{OD}\right)$ : $\delta 7.52(\mathrm{~d}, J=8.0 \mathrm{~Hz}, 2 \mathrm{H}), 7.46(\mathrm{~d}, J=8.0 \mathrm{~Hz}, 2 \mathrm{H}), 6.96(\mathrm{~d}, J=8.0 \mathrm{~Hz}, 1 \mathrm{H}), 6.75(\mathrm{~d}, J=2.6 \mathrm{~Hz}, 1 \mathrm{H}), 6.59(\mathrm{dd}, J$ $=8.4 \& 2.6 \mathrm{~Hz}, 1 \mathrm{H}), 5.09(\mathrm{~s}, 2 \mathrm{H}), 4.11(\mathrm{~s}, 2 \mathrm{H}), 3.59(\mathrm{~d}, J=4.8 \mathrm{~Hz} \& 11.0 \mathrm{~Hz}, 1 \mathrm{H}), 3.51-3.46(\mathrm{~m}, 2 \mathrm{H}), 2.97-2.83$ (m, 2H), 2.74, (s, 3H), 2.44-2.35 (m, 1H), $1.09(\mathrm{~d}, J=6.6 \mathrm{~Hz}, 3 \mathrm{H}), 0.92 \mathrm{ppm}(\mathrm{d}, J=6.8 \mathrm{~Hz}, 3 \mathrm{H}) ;{ }^{13} \mathrm{C} \mathrm{NMR}(101$ $\left.\mathrm{MHz}, \mathrm{CD}_{3} \mathrm{OD}\right) \delta 175.6,159.7,154.3,140.2,133.9,133.5,130.3,130.1,129.34,129.31,129.27,126.5,110.5$, $109.1,98.2,70.4,65.7,55.3,40.1,37.7,29.7,20.8,19.9$ ppm. LS-MS $\left[M-\mathrm{CF}_{3} \mathrm{CO}_{2}\right]=398$.

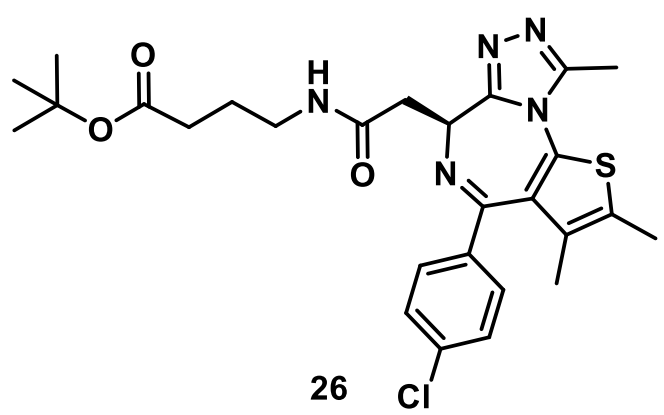

\section{Synthesis of tert-butyl (S)-4-(2-(4-(4-chlorophenyl)-2,3,9-trimethyl-6H-thieno[3,2-f][1,2,4]triazolo[4,3-}

\section{a][1,4]diazepin-6-yl)acetamido)butanoate (26)}

Freshly prepared free acid of $(+)-\mathrm{JQ}-1(20 \mathrm{mg}, 50 \mu \mathrm{mol})^{8}$ was dissolved in $1.0 \mathrm{~mL}$ DMF and treated with tertbutyl 4-aminobutanoate $(9.6 \mathrm{mg}, 60 \mu \mathrm{mol})$, PyBOP (32 mg, $30 \mu \mathrm{mol})$ and $\mathrm{Et}_{3} \mathrm{~N}(40 \mu \mathrm{L})$. Reaction mixture was stirred overnight, concentrated under reduced pressure and purified via HPLC to afford $19.5 \mathrm{mg}(72 \%)$ of $26 .{ }^{1} \mathrm{H}$ NMR (400 MHz, CD $\left.{ }_{3} \mathrm{OD}\right): \delta 7.48(\mathrm{~d}, J=8.4 \mathrm{~Hz}, 2 \mathrm{H}), 7.43(\mathrm{~d}, J=8.4 \mathrm{~Hz}, 2 \mathrm{H}), 4.71(\mathrm{dd}, J=5.2 \& 9.2 \mathrm{~Hz}, 1 \mathrm{H})$, 3.46-3.41 (m, 1H), 3.35-3.24 (m, 3H), $2.75(\mathrm{~s}, 3 \mathrm{H}), 2.46(\mathrm{~s}, 3 \mathrm{H}), 2.32(\mathrm{t}, J=7.4 \mathrm{~Hz}, 2 \mathrm{H}), 1.82(\mathrm{t}, J=7.2 \mathrm{~Hz}, 2 \mathrm{H})$, 1.71 (s, 3H), 1.44 ppm (s, 9H); ${ }^{13} \mathrm{C}$ NMR (101 MHz, $\left.\mathrm{CD}_{3} \mathrm{OD}\right) \delta$ 174.3, 172.5, 166.7, 156.8, 152.6, 138.4, 134.0, 133.3, 132.3, 132.1, 131.5, 129.9, 81.6, 54.9, 39.8, 38.4, 33.7, 28.4, 26.1, 14.4, 13.0, 11.5 ppm. LS-MS [M+H] $=542$. 


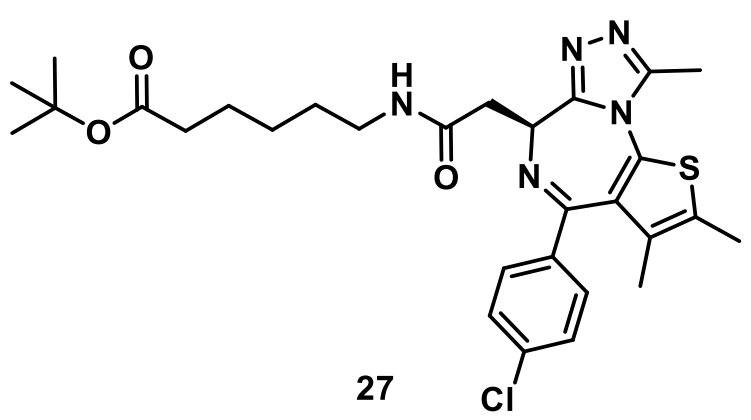

Synthesis of tert-butyl (S)-6-(2-(4-(4-chlorophenyl)-2,3,9-trimethyl-6H-thieno[3,2-f][1,2,4]triazolo[4,3-

\section{a][1,4]diazepin-6-yl)acetamido)hexanoate (27)}

Freshly prepared free acid of $(+)-\mathrm{JQ}-1(10 \mathrm{mg}, 25 \mu \mathrm{mol})^{8}$ was dissolved in $0.5 \mathrm{~mL}$ DMF and treated with tertbutyl 6 -aminohexanoate $(5.6 \mathrm{mg}, 30 \mu \mathrm{mol})$, PyBOP (16 mg, $30 \mu \mathrm{mol})$ and $\mathrm{Et}_{3} \mathrm{~N}(20 \mu \mathrm{L})$. Reaction mixture was stirred overnight, concentrated under reduced pressure and purified via HPLC to afford $12 \mathrm{mg}(85 \%)$ of $27 .{ }^{1} \mathrm{H}$ $\operatorname{NMR}\left(400 \mathrm{MHz}, \mathrm{CD}_{3} \mathrm{OD}\right): \delta 7.47(\mathrm{~d}, J=8.6 \mathrm{~Hz}, 2 \mathrm{H}), 7.42(\mathrm{~d}, J=8.6 \mathrm{~Hz}, 2 \mathrm{H}), 4.71(\mathrm{dd}, J=5.4 \& 9.0 \mathrm{~Hz}, 1 \mathrm{H})$, $3.43(\mathrm{dd}, J=9.2$ and $15.2 \mathrm{~Hz}, 1 \mathrm{H}), 3.32-3.19(\mathrm{~m}, 3 \mathrm{H}), 2.75(\mathrm{~s}, 3 \mathrm{H}), 2.45(\mathrm{~s}, 3 \mathrm{H}), 2.24-2.20(\mathrm{~m}, 2 \mathrm{H}) .1 .70(\mathrm{~s}$, 3H), 1.64-1.54 (m, 4H), 1.49-1.37 ppm (s and m, 13H); ${ }^{13} \mathrm{C}$ NMR (101 MHz, CD $\left.{ }_{3} \mathrm{OD}\right) \delta$ 174.8, 172.3, 166.7, 156.8, 152.6, 138.4, 137.45, 134.01, 133.3, 132.3, 132.06, 131.5, 129.9, 81.4, 54.9, 40.3, 38.3, 36.3, 30.2, 28.4, $27.4,25.9,14.4,13.0,11.5$ ppm. LS-MS $[\mathrm{M}+\mathrm{H}]=571$.

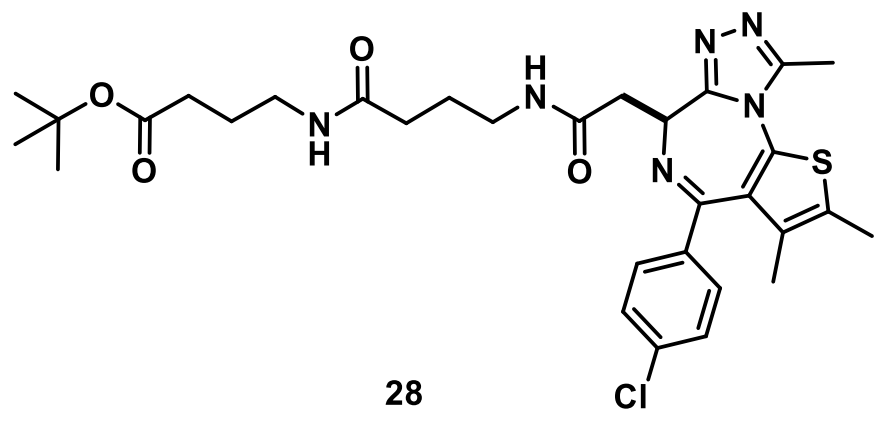

Synthesis of tert-butyl (S)-4-(4-(2-(4-(4-chlorophenyl)-2,3,9-trimethyl-6H-thieno[3,2-f][1,2,4]triazolo[4,3a][1,4]diazepin-6-yl)acetamido)butanamido)butanoate (28)

Freshly prepared free acid of $(+)-\mathrm{JQ}-1(10 \mathrm{mg}, 25 \mu \mathrm{mol})^{8}$ was dissolved in $0.5 \mathrm{~mL}$ DMF and treated with tertbutyl 4-(4-aminobutanamido)butanoate $(7.3 \mathrm{mg}, 30 \mu \mathrm{mol})$, PyBOP $(16 \mathrm{mg}, 30 \mu \mathrm{mol})$ and $\mathrm{Et}_{3} \mathrm{~N}(20 \mu \mathrm{L})$. Reaction mixture was stirred overnight, concentrated under reduced pressure and purified via HPLC to afford $12.4 \mathrm{mg}$ (79\%) of 28. ${ }^{1} \mathrm{H}$ NMR (400 MHz, CD $\left.3 \mathrm{OD}\right): \delta 7.46(\mathrm{~d}, J=8.4 \mathrm{~Hz}, 2 \mathrm{H}), 7.42(\mathrm{~d}, J=8.4 \mathrm{~Hz}, 2 \mathrm{H}), 4.69$ (dd, $J=5.8$ 
\& $9.0 \mathrm{~Hz}, 1 \mathrm{H}), 3.42(\mathrm{dd}, J=8.4 \& 15.2 \mathrm{~Hz}, 1 \mathrm{H}), 3.36-3.27(\mathrm{~m}, 3 \mathrm{H}), 3.2(\mathrm{t}, J=7.0 \mathrm{~Hz}, 2 \mathrm{H}), 2.76(\mathrm{~s}, 3 \mathrm{H}), 2.45(\mathrm{~s}$, $3 \mathrm{H}), 2.29-2.23(\mathrm{~m}, 4 \mathrm{H}), 1.89-1.82(\mathrm{~m}, 2 \mathrm{H}), 1.78-1.72(\mathrm{~m}, 2 \mathrm{H}), 1.70(\mathrm{~s}, 3 \mathrm{H}), 1.44 \mathrm{ppm}(\mathrm{s}, 9 \mathrm{H}) ;{ }^{13} \mathrm{C}$ NMR $(101$ $\left.\mathrm{MHz}, \mathrm{CD}_{3} \mathrm{OD}\right) \delta 175.4,174.2,172.6,166.6,156.9,152.4,138.2,137.7,133.7,133.5,132.2,132.0,131.4,129.9$, 81.5, 55.0, 39.9, 39.7, 38.5, 34.4, 33.7, 28.3, 26.9, 25.9, 14.4, 13.0, 11.6 ppm. LS-MS [M+H] = 628 .

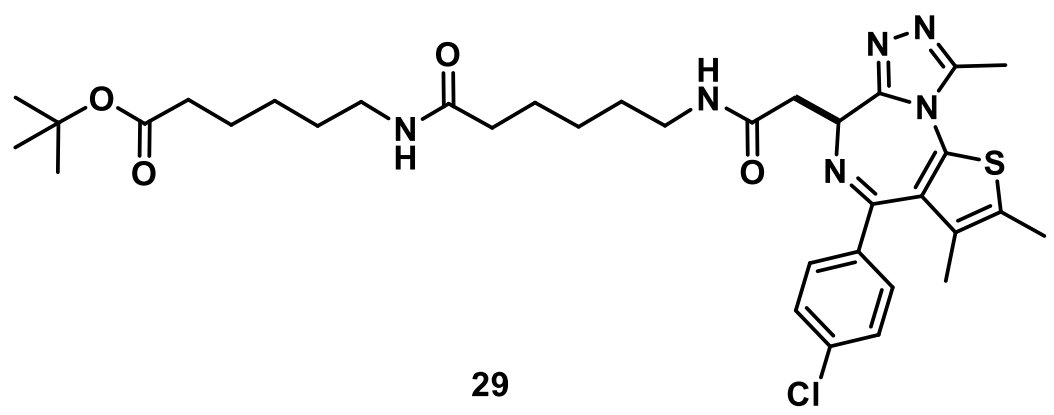

\section{Synthesis of tert-butyl (S)-6-(6-(2-(4-(4-chlorophenyl)-2,3,9-trimethyl-6H-thieno[3,2-f][1,2,4]triazolo[4,3-}

\section{a][1,4]diazepin-6-yl)acetamido)hexanamido)hexanoate (29)}

Freshly prepared free acid of $(+)-\mathrm{JQ}-1(20 \mathrm{mg}, 50 \mu \mathrm{mol})^{8}$ was dissolved in $1.0 \mathrm{~mL}$ DMF and treated with tertbutyl 6-(6-aminohexanamido)hexanoate $(18.0 \mathrm{mg}, 60 \mu \mathrm{mol})$, PyBOP (32 mg, $30 \mu \mathrm{mol})$ and $\mathrm{Et}_{3} \mathrm{~N}(40 \mu \mathrm{L})$. Reaction mixture was stirred overnight, concentrated under reduced pressure and purified via HPLC to afford $27.3 \mathrm{mg}(80 \%)$ of $29 .{ }^{1} \mathrm{H} \mathrm{NMR}\left(400 \mathrm{MHz}, \mathrm{CD}_{3} \mathrm{OD}\right): \delta 7.47$ (d, $\left.J=8.4 \mathrm{~Hz}, 2 \mathrm{H}\right), 7.43$ (d, $\left.J=8.4 \mathrm{~Hz}, 2 \mathrm{H}\right), 4.69$ (dd, $J=5.6 \& 8.8 \mathrm{~Hz}, 1 \mathrm{H}), 3.46-3.40(\mathrm{~m}, 1 \mathrm{H}), 3.35-3.26(\mathrm{~m}, 3 \mathrm{H}), 3.16(\mathrm{t}, J=7.0 \mathrm{~Hz}, 2 \mathrm{H}), 2.76(\mathrm{~s}, 3 \mathrm{H}), 2.46(\mathrm{~s}, 3 \mathrm{H})$, 2.22-2.18 (m, 4H), $1.71(\mathrm{~s}, 3 \mathrm{H}), 1.67-1.48(\mathrm{~m}, 8 \mathrm{H}), 1.43(\mathrm{~s}+\mathrm{m}, 11 \mathrm{H}), 1.37-1.28 \mathrm{ppm}(\mathrm{m}, 2 \mathrm{H}) ;{ }^{13} \mathrm{C}$ NMR (101 $\left.\mathrm{MHz}, \mathrm{CD}_{3} \mathrm{OD}\right) \delta 176.0,174.9,172.3,166.7,156.8,152.6,138.4,137.5,134.0,133.3,132.3,132.0,131.5$, $129.91,129.87,81.3,54.9,40.3,40.2,38.3,37.0,36.3,30.09,30.11,28.4,27.6,27.4,26.7,25.8,14.4,13.0$ and 11.5 ppm. LS-MS $[\mathrm{M}+\mathrm{H}]=684$.

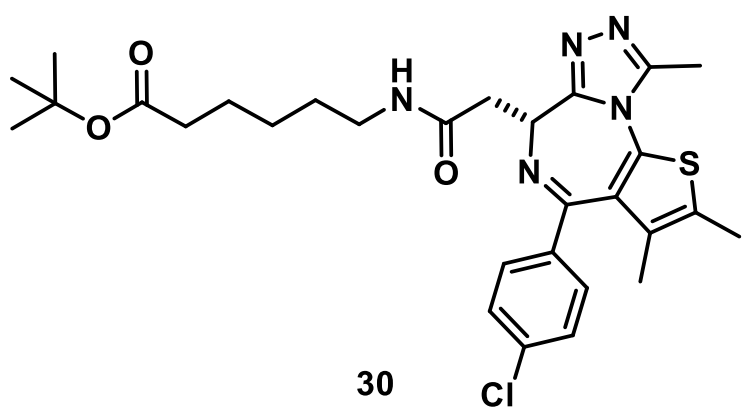




\section{Synthesis of tert-butyl (R)-6-(2-(4-(4-chlorophenyl)-2,3,9-trimethyl-6H-thieno[3,2-f][1,2,4]triazolo[4,3-}

\section{a][1,4]diazepin-6-yl)acetamido)hexanoate (30)}

Freshly prepared free acid of (-)-JQ-1 $(6 \mathrm{mg}, 15 \mu \mathrm{mol}){ }^{8}$ was dissolved in $0.25 \mathrm{~mL}$ DMF and treated with tertbutyl 6-aminohexanoate $(2.8 \mathrm{mg}, 15 \mu \mathrm{mol})$, PyBOP (8 mg, $15 \mu \mathrm{mol}$ ) and $\left.\mathrm{Et}_{3} \mathrm{~N} 10 \mu \mathrm{L}\right)$. Reaction mixture was stirred overnight, concentrated under reduced pressure and purified via HPLC to afford $5.7 \mathrm{mg}(80 \%)$ of $\mathbf{3 0}$ as a yellowish oil. ${ }^{1} \mathrm{H}$ NMR (400 MHz, $\left.\mathrm{CD}_{3} \mathrm{OD}\right): \delta 7.47(\mathrm{~d}, J=8.4 \mathrm{~Hz}, 2 \mathrm{H}), 7.42(\mathrm{~d}, J=8.4 \mathrm{~Hz}, 2 \mathrm{H}), 4.66(\mathrm{dd}, J=5.2$ \& 9.1 Hz, 1H), 3.45-3.39 (m, 1H), 3.27-3.21 (m, 3H), $2.72(\mathrm{~s}, 3 \mathrm{H}), 2.45(\mathrm{~s}, 3 \mathrm{H}), 2.23(\mathrm{t}, \mathrm{J}=7.4 \mathrm{~Hz}, 2 \mathrm{H}), 1.71(\mathrm{~s}$, 3H), 1.65-1.55 (m, 4H), 1.44-1.29 ppm (s and m, 12H); ${ }^{13} \mathrm{C}$ NMR (101 MHz, $\left.\mathrm{CD}_{3} \mathrm{OD}\right) \delta$ 174.9, 172.5, 166.4, $156.9,152.3,138.3,137.9,133.6,133.4,132.1,132.0,131.4,129.8,81.4,55.1,40.3,38.6,36.3,30.2,28.4$, $27.4,25.9,14.4,13.0,11.6$ ppm. LS-MS $[\mathrm{M}+\mathrm{H}]=571$.

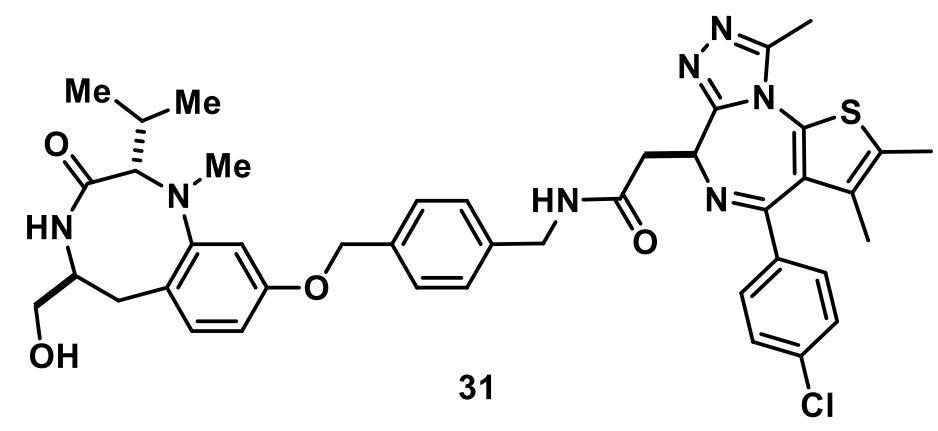

\section{Synthesis of 31}

Freshly prepared free acid of $(+)-\mathrm{JQ}-1(5 \mathrm{mg}, 12.5 \mu \mathrm{mol})^{8}$ was dissolved in $0.35 \mathrm{~mL}$ DMF and was treated with freshly prepared 25 (6.4 mg, $12.5 \mu \mathrm{mol})$ followed by PyBOP (8.8 mg) and $\mathrm{Et}_{3} \mathrm{~N}(25 \mu \mathrm{L})$. Reaction was stirred overnight, concentrated under reduced pressure and purified via HPLC affording $5.5 \mathrm{mg}(56 \%)$ of desired product 31 as an off-white solid. ${ }^{1} \mathrm{H}$ NMR $\left(400 \mathrm{MHz}, \mathrm{CD}_{3} \mathrm{OD}\right): 7.49-7.32(\mathrm{~m}, 8 \mathrm{H}), 6.97(\mathrm{~d}, J=8.4 \mathrm{~Hz}, 1 \mathrm{H}), 6.72(\mathrm{~d}, J=$ $2.4 \mathrm{~Hz}, 1 \mathrm{H}), 6.58(\mathrm{dd}, J=8.4 \& 2.4 \mathrm{~Hz}, 1 \mathrm{H}), 5.04(\mathrm{~s}, 2 \mathrm{H}), 4.68(\mathrm{dd}, J=9.6 \& 4.2 \mathrm{~Hz}, 1 \mathrm{H}), 4.60(\mathrm{~d}, J=14.8 \mathrm{~Hz}$, 1H), $4.35(\mathrm{~d}, J=14.8 \mathrm{~Hz}, 1 \mathrm{H}), 4.24(\mathrm{~s}, 1 \mathrm{H}), 3.59(\mathrm{dd}, J=11.2 \& 4.8 \mathrm{~Hz}, 1 \mathrm{H}), 3.53-3.45(\mathrm{~m}, 3 \mathrm{H}), 2.95-2.87$ (m, 2H), $2.74(\mathrm{~s}, 3 \mathrm{H}), 2.72(\mathrm{~s}, 3 \mathrm{H}), 2.45(\mathrm{~s}, 3 \mathrm{H}), 2.45-2.35(\mathrm{~m}, 1 \mathrm{H}), 1.68(\mathrm{~s}, 3 \mathrm{H}), 1.07$ (d, J = 6.4 Hz, 3H), $0.91 \mathrm{ppm}$ (d, $J=6.4 \mathrm{~Hz}, 3 \mathrm{H}) ;{ }^{13} \mathrm{C}$ NMR $\left(101 \mathrm{MHz}, \mathrm{CD}_{3} \mathrm{OD}\right) \delta 172.6,166.5,159.9,156.9,154.2,139.8,138.1,137.9,137.8$, 133.6, 133.5, 133.4, 132.2, 132.1, 131.4, 129.8, 128.9, 128.8, 110.3, 110.9, 70.8, 65.8, 55.4, 55.2, 43.9, 38.7, $37.8,36.7,29.6,24.2,20.7,20,14.4,12.9$ and 11.5 ppm. LS-MS $[\mathrm{M}+\mathrm{H}]=780$. 


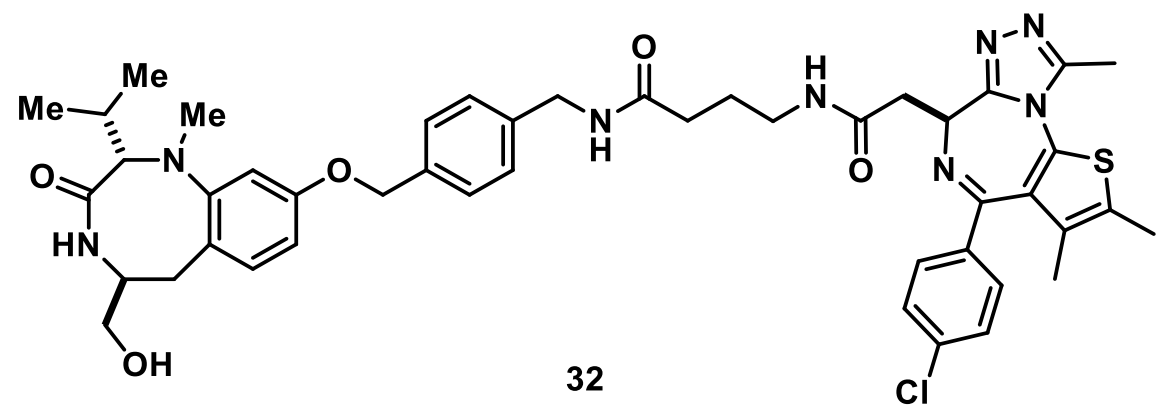

\section{Synthesis of 32}

Solution of $26(13.5 \mathrm{mg}, 25 \mu \mathrm{mol})$ in $1.25 \mathrm{~mL}$ of DCM was cooled to $0^{\circ} \mathrm{C}$ and treated with trifluoroacetic acid $(0.35$ $\mathrm{mL})$. Reaction mixture was warmed to room temperature and stirred for 3 hours before solvent was concentrated under reduced pressure. Freshly prepared 25 (12.8 mg, $25 \mu \mathrm{mol}$ ) was added in $0.7 \mathrm{~mL}$ DMF followed by PyBOP (17.5 mg) and $\mathrm{Et}_{3} \mathrm{~N}(50 \mu \mathrm{L})$. Reaction was stirred overnight, concentrated under reduced pressure and purified via HPLC affording $14.7 \mathrm{mg}(68 \%)$ of desired product 32 as an off-white solid. ${ }^{1} \mathrm{H}$ NMR (400 MHz, CD $\left.{ }_{3} \mathrm{OD}\right): 7.45$ (d, $J=8.6 \mathrm{~Hz}, 2 \mathrm{H}), 7.40(\mathrm{~d}, J=8.4 \mathrm{~Hz}, 2 \mathrm{H}), 7.36(\mathrm{~d}, J=8.0 \mathrm{~Hz}, 2 \mathrm{H}), 7.27(\mathrm{~d}, J=8.0 \mathrm{~Hz}, 2 \mathrm{H}), 6.95(\mathrm{~d}, J=8.4$ $\mathrm{Hz}, 1 \mathrm{H}), 6.71(\mathrm{~d}, J=2.4 \mathrm{~Hz}, 1 \mathrm{H}), 6.55(\mathrm{dd}, J=8.4 \& 2.4 \mathrm{~Hz}, 1 \mathrm{H}), 5.01(\mathrm{~s}, 2 \mathrm{H}), 4.69(\mathrm{dd}, J=8.4 \& 5.6 \mathrm{~Hz}, 1 \mathrm{H})$, $4.37(\mathrm{dd}, J=14.8 \& 6.4 \mathrm{~Hz}, 1 \mathrm{H}), 4.24(\mathrm{~s}, 1 \mathrm{H}), 3.59(\mathrm{dd}, J=10.8 \& 6.4 \mathrm{~Hz}, 1 \mathrm{H}), 3.50-3.39(\mathrm{~m}, 3 \mathrm{H}), 2.94-2.87$ (m, 2H), 2.73 (s, 3H), $2.70(\mathrm{~s}, 3 \mathrm{H}), 2.43(\mathrm{~s}, 3 \mathrm{H}), 2.36-2.32(\mathrm{~m}, 2 \mathrm{H}), 1.68(\mathrm{~s}, 3 \mathrm{H}), 1.07(\mathrm{~d}, \mathrm{~J}=6.4 \mathrm{~Hz}, 3 \mathrm{H}), 0.91$ ppm (d, $J=6.4 \mathrm{~Hz}, 3 \mathrm{H}) ;{ }^{13} \mathrm{C}$ NMR $\left(101 \mathrm{MHz}, \mathrm{CD}_{3} \mathrm{OD}\right) \delta$ 175.3, 166.6, 159.8, 154.2, 139.6, 138.2, 138.1, 137.8, 137.7, 133.6, 133.5, 132.2, 131.9, 131.4, 129.9, 128.9, 128.8, 128.6, 126.1, 110.2, 108.9, 70.7, 65.8, 55.4, 55.0, $43.9,39.9,38.5,37.7,36.8,34.4,29.6,26.9,20.7,20.0,14.4,13.0$ and 11.6 ppm. LS-MS $[M+H]=866$.

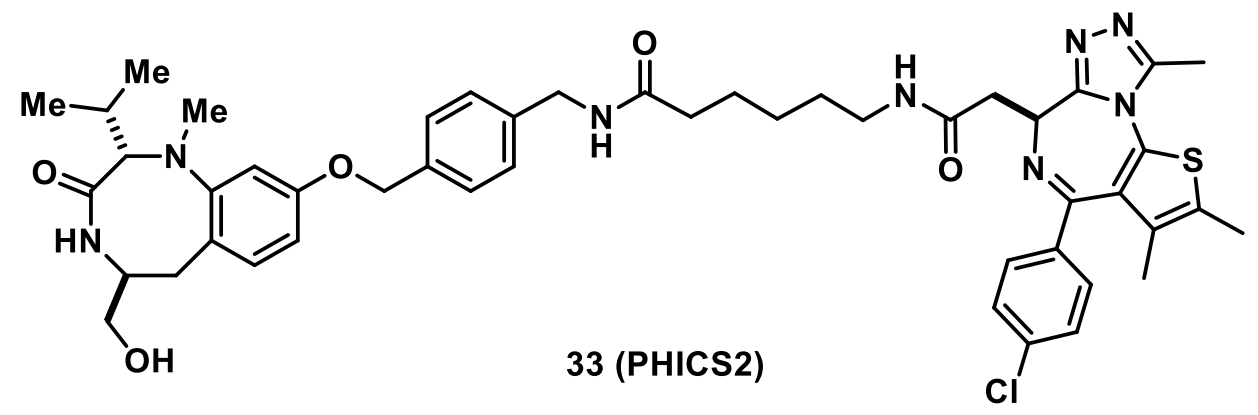

\section{Synthesis of 33 (PHICS2)}


Solution of $27(11.4 \mathrm{mg}, 20 \mu \mathrm{mol})$ in $1 \mathrm{~mL}$ of $\mathrm{DCM}$ was cooled to $0^{\circ} \mathrm{C}$ and treated with trifluoroacetic acid $(0.3$ $\mathrm{mL}$ ). Reaction mixture was warmed to room temperature and stirred for 3 hours before solvent was concentrated under reduced pressure. Freshly prepared $25(10.2 \mathrm{mg}, 20 \mu \mathrm{mol})$ was added in $0.5 \mathrm{~mL}$ DMF followed by PyBOP (14 mg) and $\mathrm{Et}_{3} \mathrm{~N}(40 \mu \mathrm{L})$. Reaction was stirred overnight, concentrated under reduced pressure and purified via HPLC affording $9 \mathrm{mg} \mathrm{(50 \% )} \mathrm{of} \mathrm{desired} \mathrm{product} 33$ (PHICS2) as an off-white solid. ${ }^{1} \mathrm{H}$ NMR (400 $\left.\mathrm{MHz}, \mathrm{CD}{ }_{3} \mathrm{OD}\right)$ : 7.45-7.36 (m, 6H), $7.27(\mathrm{~d}, J=7.6 \mathrm{~Hz}, 2 \mathrm{H}), 6.94(\mathrm{~d}, J=8.4 \mathrm{~Hz}, 1 \mathrm{H}), 6.71(\mathrm{~d}, J=2.4 \mathrm{~Hz}, 1 \mathrm{H}), 6.54(\mathrm{dd}, J=8.4$ and $2.4 \mathrm{~Hz}, 1 \mathrm{H}), 5.00(\mathrm{~s}, 2 \mathrm{H}), 4.63(\mathrm{dd}, J=5.4 \& 8.6 \mathrm{~Hz}, 1 \mathrm{H}), 4.36(\mathrm{~s}, 2 \mathrm{H}), 4.23(\mathrm{br} \mathrm{s}, 1 \mathrm{H}), 3.61-3.57(\mathrm{~m}, 1 \mathrm{H})$, 3.50-3.37 (m, 3H), 3.28-3.23 (m, 2H), 2.91-2.87 (m, 2H), $2.72(\mathrm{~s}, 3 \mathrm{H}), 2.68(\mathrm{~s}, 3 \mathrm{H}), 2.43(\mathrm{~s}, 3 \mathrm{H}), 2.26(\mathrm{t}, J=7.6$ $\mathrm{Hz}, 2 \mathrm{H}), 1.69$ (s and m, 4H), 1.63-1.55 (m, 3H), $1.45-1.39(\mathrm{~m}, 2 \mathrm{H}), 1.33-1.29(\mathrm{~m}, 2 \mathrm{H}), 1.07(\mathrm{~d}, J=6.6 \mathrm{~Hz}, 3 \mathrm{H})$ and $0.9(\mathrm{~d}, J=6.6 \mathrm{~Hz}, 3 \mathrm{H}) ;{ }^{13} \mathrm{C}$ NMR $\left(101 \mathrm{MHz}, \mathrm{CD}_{3} \mathrm{OD}\right) \delta 175.9,175.6,167.0,159.8,154.1,139.7,138.7$, $137.8,137.1,134.4,133.5,132.5,132.0,131.6,129.9,128.91,128.87,128.8,128.7,126.1,110.3,108.9,70.7$, $65.8,55.4,54.8,44.0,43.8,40.3,38.1,37.7,36.9,36.8,30.1,29.7,27.5,26.6,20.7,20.0,14.4,13.0,11.5$ ppm. HRMS (ESI-TOF): calculated for $\mathrm{C}_{48} \mathrm{H}_{58} \mathrm{CIN}_{8} \mathrm{O}_{5} \mathrm{~S}(\mathrm{M}+\mathrm{H}):$ 893.3934, found: 893.3935.

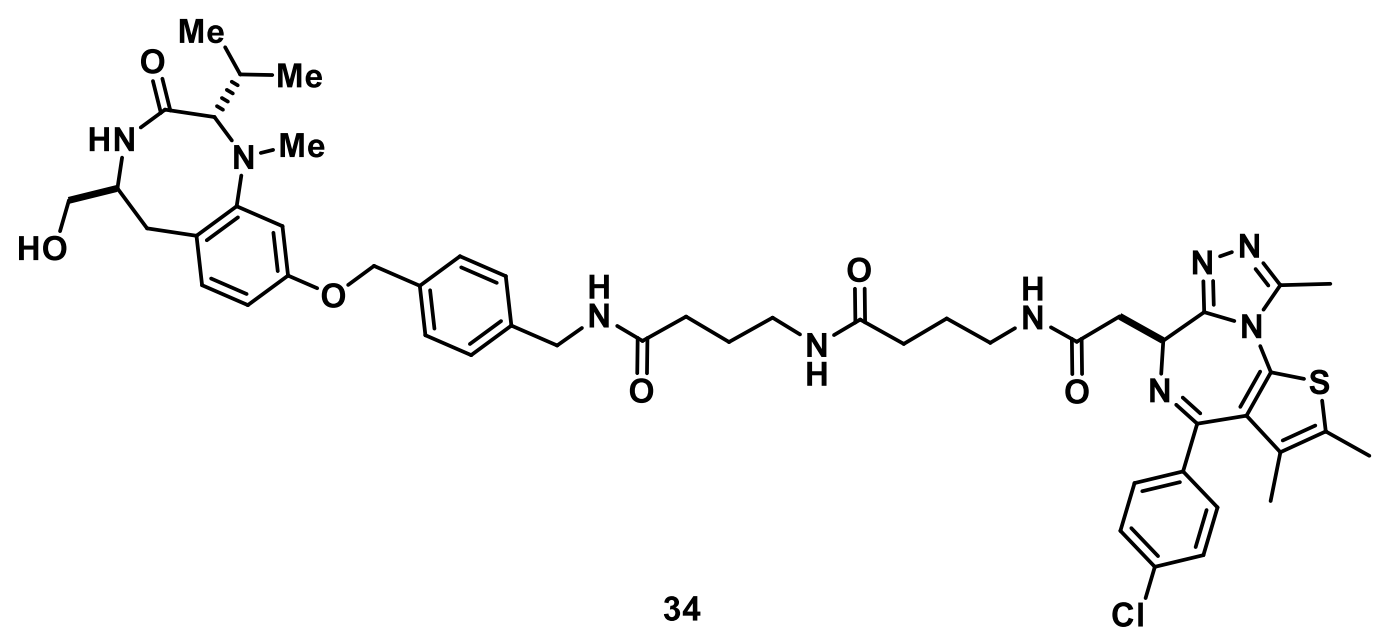

\section{Synthesis of 34}

Solution of $28(12.4 \mathrm{mg}, 19.8 \mu \mathrm{mol})$ in $1 \mathrm{~mL}$ of $\mathrm{DCM}$ was cooled to $0{ }^{\circ} \mathrm{C}$ and treated with trifluoroacetic acid $(0.3$ $\mathrm{mL}$ ). Reaction mixture was warmed to room temperature and stirred for 3 hours before solvent was concentrated under reduced pressure. Freshly prepared 25 (10.2 mg, 20 umol) was added in $0.5 \mathrm{~mL}$ DMF followed by PyBOP (14 mg) and $\mathrm{Et}_{3} \mathrm{~N}(40 \mu \mathrm{L})$. Reaction was stirred overnight, concentrated under reduced pressure and purified via HPLC affording $9.2 \mathrm{mg} \mathrm{(49 \% )} \mathrm{of} \mathrm{desired} \mathrm{product} 34$ as an off-white solid. ${ }^{1} \mathrm{H}$ NMR (400 MHz, CD $\left.{ }_{3} \mathrm{OD}\right): 7.45$ (d, 
$J=8.4 \mathrm{~Hz}, 2 \mathrm{H}), 7.41(\mathrm{~d}, J=8.4 \mathrm{~Hz}, 2 \mathrm{H}), 7.35(\mathrm{~d}, J=8.0 \mathrm{~Hz}, 2 \mathrm{H}), 7.25(\mathrm{~d}, J=7.6 \mathrm{~Hz}, 2 \mathrm{H}), 6.95(\mathrm{~d}, J=8.4 \mathrm{~Hz}$, $1 \mathrm{H}), 6.71(\mathrm{~d}, J=2.4 \mathrm{~Hz}, 1 \mathrm{H}), 6.54(\mathrm{dd}, J=8.4$ and $2.4 \mathrm{~Hz}, 1 \mathrm{H}), 5.00(\mathrm{~s}, 2 \mathrm{H}), 4.63(\mathrm{dd}, J=5.8 \& 8.4 \mathrm{~Hz}, 1 \mathrm{H})$, $4.33(\mathrm{~s}, 2 \mathrm{H}), 4.24(\mathrm{br} s, 1 \mathrm{H}), 3.59(\mathrm{dd}, J=10.8$ \& $4.8 \mathrm{~Hz}, 1 \mathrm{H}), 3.50-3.45(\mathrm{~m}, 2 \mathrm{H}), 3.42-3.34(\mathrm{~m}, 3 \mathrm{H}), 3.23-3.18$ $(\mathrm{m}, 2 \mathrm{H}), 2.94-2.87(\mathrm{~m}, 2 \mathrm{H}), 2.73(\mathrm{~s}, 3 \mathrm{H}), 2.69(\mathrm{~s}, 3 \mathrm{H}), 2.44(\mathrm{~s}, 3 \mathrm{H}), 2.41-2.36(\mathrm{~m}, 1 \mathrm{H}), 2.28-2.23(\mathrm{~m}, 4 \mathrm{H}), 1.89-$ $1.77(\mathrm{~m}, 4 \mathrm{H}), 1.68(\mathrm{~s}, \mathrm{H}), 1.45-1.39(\mathrm{~m}, 2 \mathrm{H}), 1.07(\mathrm{~d}, J=6.8 \mathrm{~Hz}, 3 \mathrm{H})$ and $0.9(\mathrm{~d}, J=6.8 \mathrm{~Hz}, 3 \mathrm{H}) ;{ }^{13} \mathrm{C}$ NMR $(101$ $\left.\mathrm{MHz}, \mathrm{CD}_{3} \mathrm{OD}\right) \delta 175.5,166.5,159.8,154.2,139.6,137.8,133.5,132.2,131.4,129.9,128.8,128.7,110.2,108.9$, $70.7,65.8,55.4,55.1,43.9,39.9,39.8,38.6,37.7,34.4,34.3,29.6,26.8,20.7,20.0,14.4,12.9$ and 11.6 ppm. LS-MS $[\mathrm{M}+\mathrm{H}]=951$.

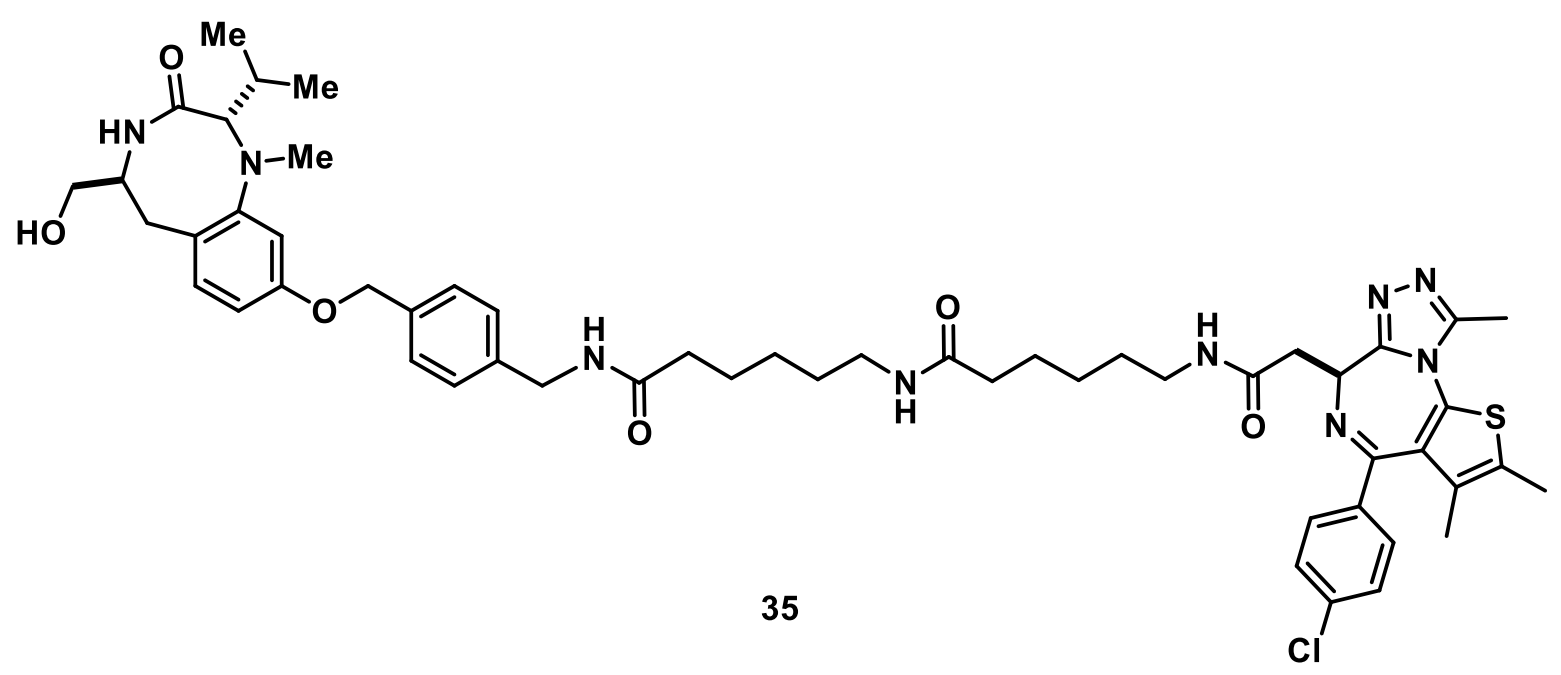

\section{Synthesis of 35}

Solution of $29(17.1 \mathrm{mg}, 25 \mu \mathrm{mol})$ in $1.25 \mathrm{~mL}$ of DCM was cooled to $0{ }^{\circ} \mathrm{C}$ and treated with trifluoroacetic acid $(0.35$ $\mathrm{mL}$ ). Reaction mixture was warmed to room temperature and stirred for 3 hours before solvent was concentrated under reduced pressure. Freshly prepared $25(12.8 \mathrm{mg}, 25 \mu \mathrm{mol})$ was added in $0.7 \mathrm{~mL}$ DMF followed by PyBOP (17.5 mg) and $\mathrm{Et}_{3} \mathrm{~N}(50 \mu \mathrm{L})$. Reaction was stirred overnight, concentrated under reduced and purified via HPLC affording $15.0 \mathrm{mg}(60 \%)$ of desired product 35 as an off-white solid. ${ }^{1} \mathrm{H}$ NMR $\left(400 \mathrm{MHz}, \mathrm{CD}_{3} \mathrm{OD}\right):{ }^{1} \mathrm{H}$ NMR $(400$ $\left.\mathrm{MHz}, \mathrm{CD}_{3} \mathrm{OD}\right): 7.46(\mathrm{~d}, J=8.4 \mathrm{~Hz}, 2 \mathrm{H}), 7.42(\mathrm{~d}, J=8.4 \mathrm{~Hz}, 2 \mathrm{H}), 7.37(\mathrm{~d}, J=8.0 \mathrm{~Hz}, 2 \mathrm{H}), 7.26(\mathrm{~d}, J=7.6 \mathrm{~Hz}$, 2H), $6.95(\mathrm{~d}, J=8.4 \mathrm{~Hz}, 1 \mathrm{H}), 6.72(\mathrm{~d}, J=2.8 \mathrm{~Hz}, 1 \mathrm{H}), 6.56(\mathrm{dd}, J=8.4$ and $2.8 \mathrm{~Hz}, 1 \mathrm{H}), 5.00(\mathrm{~s}, 2 \mathrm{H}), 4.69(\mathrm{dd}$, $J=5.6 \& 8.4 \mathrm{~Hz}, 1 \mathrm{H}), 4.34(\mathrm{~s}, 2 \mathrm{H}), 4.25(\mathrm{br} \mathrm{s}, 1 \mathrm{H}), 3.59(\mathrm{dd}, J=10.8 \& 4.8 \mathrm{~Hz}, 1 \mathrm{H}), 3.49-3.35(\mathrm{~m}, 4 \mathrm{H}), 3.27-$ $3.23(\mathrm{~m}, 3 \mathrm{H}), 3.17-3.13(\mathrm{~m}, 2 \mathrm{H}), 2.91-2.87(\mathrm{~m}, 3 \mathrm{H}), 2.74(\mathrm{~s}, 3 \mathrm{H}), 2.73(\mathrm{~s}, 3 \mathrm{H}), 2.45(\mathrm{~s}, 3 \mathrm{H}), 2.41-2.34(\mathrm{~m}, 1 \mathrm{H})$, 2.25-2.17 (m, 4H), $1.70(\mathrm{~s}, \mathrm{H}), 1.67-1.31(\mathrm{~m}, 15 \mathrm{H}), 1.07(\mathrm{~d}, J=6.8 \mathrm{~Hz}, 3 \mathrm{H})$ and $0.90(\mathrm{~d}, J=6.8 \mathrm{~Hz}, 3 \mathrm{H}) ;{ }^{13} \mathrm{C}$ 
$\operatorname{NMR}\left(101 \mathrm{MHz}, \mathrm{CD}_{3} \mathrm{OD}\right) \delta$ 175.5, 166.5, 159.8, 154.2, 139.6, 137.8, 133.5, 132.2, 131.4, 129.9, 128.8, 128.7, $110.2,108.9,70.7,65.8,55.4,55.1,43.9,39.9,39.8,38.6,37.7,34.4,34.3,29.6,26.8,20.7,20.0,14.4,12.9$ and $11.6 \mathrm{ppm} ;{ }^{13} \mathrm{C}$ NMR $\left(101 \mathrm{MHz}, \mathrm{CD}_{3} \mathrm{OD}\right) \delta$ 176.0, 175.9, 172.3, 166.7, 159.8, 154.2, 139.7, 138.4, 137.8, 137.5, 134.0, 133.5, 132.3, 132.0, 131.5, 129.9, 128.8, 128.7, 70.7, 65.8, 55.4, 54.9, 43.8, 40.3, 40.2, 38.3, 37.7, 37.0, 36.9, 30.1, 29.7, 27.5, 26.71, 26.66, 20.7, 20.0, 14.4, 13.0 and 11.6 ppm. LS-MS $[M+H]=1007$.

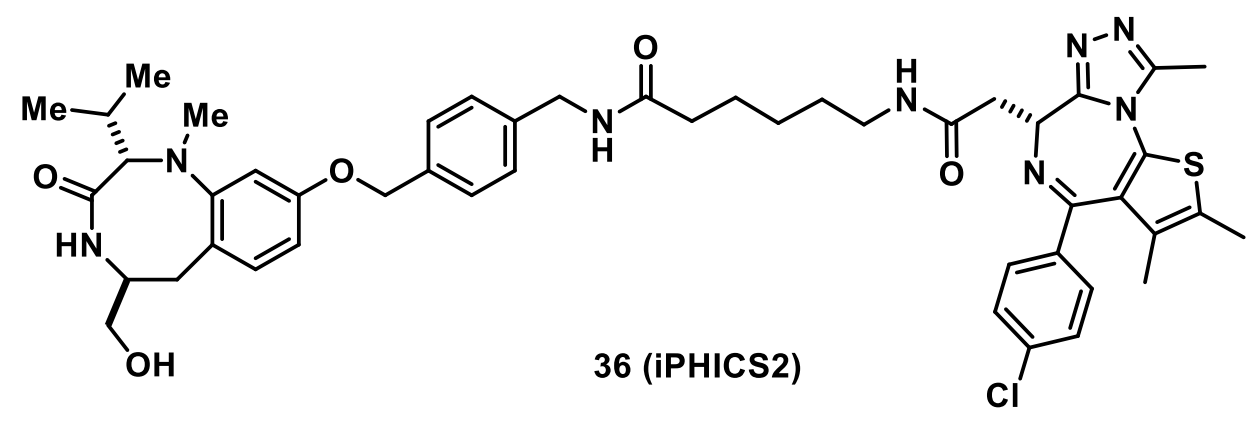

\section{Synthesis of 36 (iPHICS2)}

Solution of $30(5.7 \mathrm{mg}, 12 \mu \mathrm{mol})$ in $0.6 \mathrm{~mL}$ of $\mathrm{DCM}$ was cooled to $0{ }^{\circ} \mathrm{C}$ and treated with trifluoroacetic acid $(0.18$ $\mathrm{mL})$. Reaction mixture was warmed to room temperature and stirred for 3 hours before solvent was concentrated under reduced pressure. Freshly prepared $25(6.1 \mathrm{mg}, 12 \mu \mathrm{mol})$ was added in $0.3 \mathrm{~mL}$ DMF followed by PyBOP (8.4 mg) and $\mathrm{Et}_{3} \mathrm{~N}(24 \mu \mathrm{L})$. Reaction was stirred overnight, concentrated under reduced and purified via HPLC affording $6.8 \mathrm{mg}(63 \%)$ of desired product iPHICS2 as an off-white solid. ${ }^{1} \mathrm{H}$ NMR (400 MHz, CD $\left.{ }_{3} \mathrm{OD}\right): 7.45$ (d, $J=8.6 \mathrm{~Hz}, 2 \mathrm{H}), 7.41(\mathrm{~d}, J=8.6 \mathrm{~Hz}, 2 \mathrm{H}), 7.37(\mathrm{~d}, J=8.0 \mathrm{~Hz}, 2 \mathrm{H}) 7.27(\mathrm{~d}, J=8.0 \mathrm{~Hz}, 2 \mathrm{H}), 6.94(\mathrm{~d}, J=8.4 \mathrm{~Hz}$, $1 \mathrm{H}), 6.71(\mathrm{~d}, J=2.5 \mathrm{~Hz}, 1 \mathrm{H}), 6.54(\mathrm{dd}, J=8.4$ and $2.5 \mathrm{~Hz}, 1 \mathrm{H}), 5.00(\mathrm{~s}, 2 \mathrm{H}), 4.66$ (dd, $J=5.5 \& 8.7 \mathrm{~Hz}, 1 \mathrm{H}$ ), $4.36(\mathrm{~s}, 2 \mathrm{H}), 4.24$ (br s, 1H), 3.61-3.57 (m, 1H), 3.50-3.47 (m, 2H), 3.27-3.24 (m, 2H), 2.91-2.87 (m, 2H), 2.72 (s, 3H), $2.70(\mathrm{~s}, 3 \mathrm{H}), 2.43(\mathrm{~s}, 3 \mathrm{H}), 2.41-2.34(\mathrm{~m}, 1 \mathrm{H}), 2.26(\mathrm{t}, J=7.4 \mathrm{~Hz}, 2 \mathrm{H}), 1.72-1.67$ (s and $\mathrm{m}, 4 \mathrm{H}), 1.63-$ $1.55(\mathrm{~m}, 2 \mathrm{H}), 1.45-1.39(\mathrm{~m}, 2 \mathrm{H}), 1.33-1.29(\mathrm{~m}, 2 \mathrm{H}), 1.07(\mathrm{~d}, J=6.5 \mathrm{~Hz}, 3 \mathrm{H})$ and $0.9 \mathrm{ppm}(\mathrm{d}, J=6.7 \mathrm{~Hz}, 3 \mathrm{H})$. ${ }^{13} \mathrm{C}$ NMR (101 MHz, CD3OD) $\delta$ 175.9, 175.6, 172.6, 166.4, 159.8, 158.4, 154.2, 152.3, 139.7, 138.1, 137.9, 137.8, 133.4, 132.1, 132.0, 131.4, 131.1, 129.9, 128.8, 128.7, 128.7, 126.1, 124.3, 121.7, 111.8, 110.2, 108.9, $70.7,65.8,56.2,55.4,55.1,45.3,43.8,40.3,38.7,37.7,37.0,30.1,29.7,27.5,26.7,20.7,20.0,14.4,13.0,11.6$ ppm. LS-MS $[\mathrm{M}+\mathrm{H}]=894$. 


\subsection{Synthesis of PHICS3 and Piv-PHICS3}

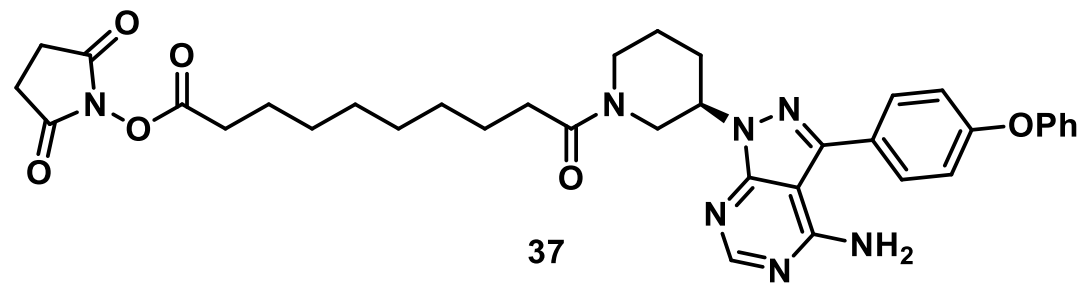

Synthesis of 2,5-dioxopyrrolidin-1-yl (R)-10-(3-(4-amino-3-(4-phenoxyphenyl)-1H-pyrazolo[3,4d]pyrimidin-1-yl)piperidin-1-yl)-10-oxodecanoate (37)

To the solution of $39.6 \mathrm{mg}(0.1 \mathrm{mmol}, 1 \mathrm{eq})$ of sebacic acid bis(N-succinimidyl) ester in $1 \mathrm{~mL}$ DMF was added $38.6 \mathrm{mg}(0.1 \mathrm{mmol}, 1 \mathrm{eq})$ of (R)-3-(4-phenoxyphenyl)-1-(1-piperidin-3-yl)-1H-pyrazolo[3,4-d]pyrimidin-4-amine. Reaction mixture was stirred at room temperature for 1 hour, concentrated under reduced pressure and purified by silica gel column chromatography (DCM : MeOH gradient from 100:0 to 95:5) affording $20 \mathrm{mg}(30 \%)$ of desired product 37 as a white solid. ${ }^{1} \mathrm{H}$ NMR $\left(400 \mathrm{MHz}, \mathrm{CD}_{3} \mathrm{Cl}\right): 8.31$ (br s, $\left.1 \mathrm{H}\right), 7.62$ (t, J = $\left.8 \mathrm{~Hz}, 2 \mathrm{H}\right), 7.40-7.37$ (m, 2H), 7.19-7.13 (m, 3H), $7.08(\mathrm{~d}, 8 \mathrm{~Hz}, 2 \mathrm{H}), 4.87-4.76(\mathrm{~m}, 1.5 \mathrm{H}), 4.58(\mathrm{~d}, \mathrm{~J}=12 \mathrm{~Hz}, 0.5 \mathrm{H}), 4.05(\mathrm{dd}, \mathrm{J}=12 \& 4$ $\mathrm{Hz}, 0.5 \mathrm{H}), 3.89(\mathrm{~d}, \mathrm{~J}=16 \mathrm{~Hz}, 0.5 \mathrm{H}), 3.68-3.62(\mathrm{~m}, 0.5 \mathrm{H}), 3.31-3.25(\mathrm{~m}, 0.5 \mathrm{H}), 3.17-3.10(\mathrm{~m}, 0.5 \mathrm{H}), 2.87-2.78$ (m, 3H), 2.74-2.67 (m, 2H), 2.61-2.55 (m, 2H), 2.42-2.18 (m, 2H), 2.00-1.92 (m, 1H), 1.77-1.55 (m, 5H), 1.401.25 ppm (m, 9H). ${ }^{13} \mathrm{C}$ NMR (101 MHz, $\left.\mathrm{CD}_{3} \mathrm{Cl}\right) \delta$ 173.22, 171.96, 171.90, 169.29, 168.69, 158.69, 158.59, $157.74,156.30,156.24,154.85,154.59,153.96,153.76,144.41,130.02,130.00,129.97,129.94,127.50$, 127.34, 124.15, 124.08, 119.59, 119.56, 119.52, 119.16, 118.98, 53.53, 52.66, 49.96, 45.63, 41.69, 33.51, 33.46, $30.97,30.93,30.34,29.99,29.70,29.36,29.32,29.19,29.12,29.09,28.93,28.70,25.62,25.51,25.34,25.30$, $25.15,24.55,24.06$ ppm. LS-MS $[\mathrm{M}+\mathrm{H}]=668.5$. 


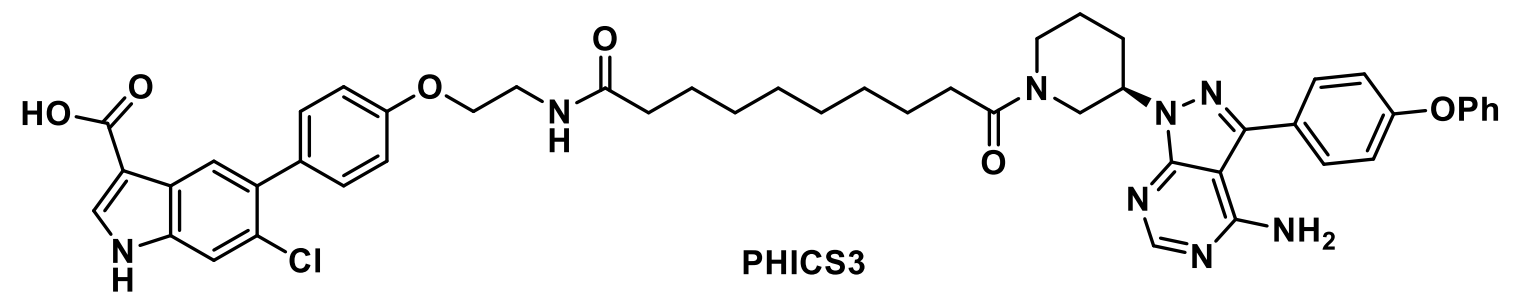

\section{Synthesis of PHICS3}

Solution of $3(28 \mathrm{mg}, 65 \mu \mathrm{mol})$ in $1 \mathrm{~mL}$ of $\mathrm{DCM}$ was cooled to $0^{\circ} \mathrm{C}$ and treated with trifluoroacetic acid $(0.1 \mathrm{~mL})$. Reaction mixture was warmed to room temperature and stirred for 2 hours before solvent was concentrated under reduced pressure. Freshly prepared $37(40 \mathrm{mg}, 60 \mu \mathrm{mol})$ was added in $1 \mathrm{~mL}$ DMF followed by DIPEA (40 $\mu \mathrm{L})$. Reaction was stirred overnight, concentrated under reduced pressure and purified via HPLC affording 30 mg (57\%) of desired product PHICS3 as a white solid. ${ }^{1} \mathrm{H}$ NMR (400 MHz, DMSO- $\left.d_{6}\right): 11.91$ (br s, $\left.1 \mathrm{H}\right), 8.25$ (d, $\mathrm{J}=8 \mathrm{~Hz}, 1 \mathrm{H}), 8.04(\mathrm{br} \mathrm{s}, 2 \mathrm{H}), 7.94(\mathrm{~s}, 1 \mathrm{H}), 7.66-7.62(\mathrm{~m}, 2 \mathrm{H}), 7.61(\mathrm{~s}, 1 \mathrm{H}), 7.45-7.41(\mathrm{~m}, 2 \mathrm{H}), 7.36-7.31(\mathrm{~m}$, 2H), 7.21-7.09 (m, 4H), 7.04-6.97 (m, 2H), 4.77-4.68 (m, 0.5H), 4.65-4.56 (m, 0.5H), 4.53-4.46 (m, 0.5H), 4.18-4.11 (m, 0.5H), 4.06-3.96 (m, 2.5H), 3.89-3.81 (m, 0.5H), 3.61-3.55 (m, 0.5H), 3.48-3.40 (m, 2H), 3.15$3.06(\mathrm{~m}, 1.5 \mathrm{H}), 2.93-2.83(\mathrm{~m}, 0.5 \mathrm{H}), 2.36-2.20(\mathrm{~m}, 3 \mathrm{H}), 2.15-2.04(\mathrm{~m}, 3 \mathrm{H}), 1.93-1.83(\mathrm{~m}, 1 \mathrm{H}), 1.65-1.37(\mathrm{~m}$, $5 \mathrm{H}), 1.24-1.15(\mathrm{~m}, 8 \mathrm{H}) .{ }^{13} \mathrm{C}$ NMR (100 MHz, DMSO-d $): 172.55,170.82,170.71,170.31,165.61,162.29,158.19$, $157.65,157.12,156.30,155.62,154.04,153.90,143.23,143.15,135.93,133.75,132.79,132.50,130.75$, $130.09,130.05,127.95,127.80,125.84,125.27,123.76,122.71,118.95,114.02,112.86,107.61,97.48,97.37$, $73.54,66.41,59.75,52.71,52.11,49.31,45.30,45.00,41.08,38.23,35.77,35.34,32.38,30.77,29.60,29.22$ 28.79, 28.72, 28.64, 25.28, 24.94, 24.84, 24.69, 23.46, 20.74, 14.07 ppm. HRMS (ESI-TOF): calculated for $\mathrm{C}_{49} \mathrm{H}_{52} \mathrm{CIN}_{8} \mathrm{O}_{6}(\mathrm{M}+\mathrm{H}): 883.3693$, found: 883.3690 .

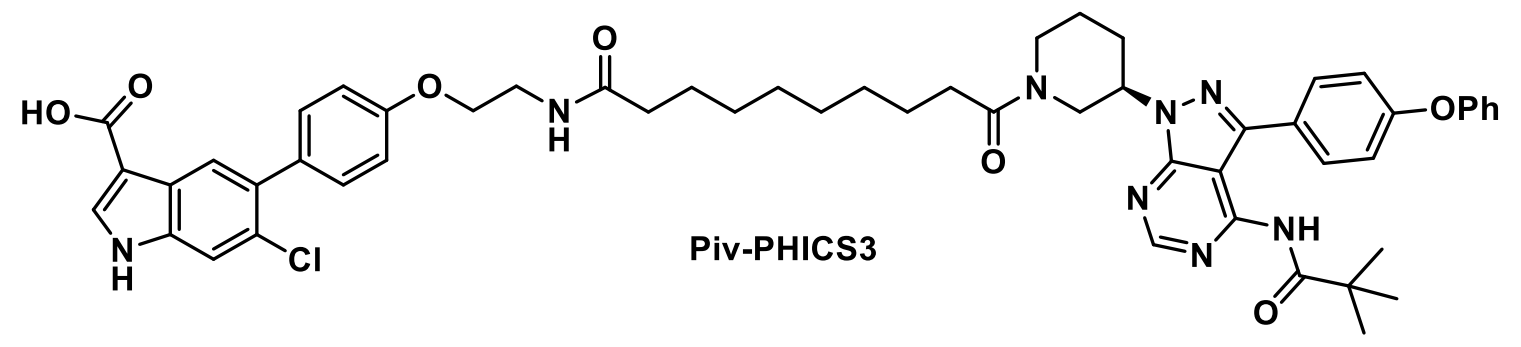

\section{Synthesis of Piv-PHICS3}

Step 1: Solution of $37(20 \mathrm{mg}, 30 \mu \mathrm{mol})$ in $\mathrm{DCM}(0.5 \mathrm{~mL})$ was cooled to zero and treated with pivaloyl chloride $(10 \mu \mathrm{L}, 80 \mu \mathrm{mol})$ and DIPEA $(20 \mu \mathrm{L})$ at zero. Reaction mixture was warmed to room temperature, stirred for 2 
hours and concentrated under reduced pressure affording crude $\mathbf{3 8}$. Product $\mathbf{3 8}$ was used in the next step without further purification.

Step 2: Solution of $3(13 \mathrm{mg}, 30 \mu \mathrm{mol})$ in $0.5 \mathrm{~mL}$ of DCM was cooled to $0^{\circ} \mathrm{C}$ and treated with trifluoroacetic acid $(0.1 \mathrm{~mL})$. Reaction mixture was warmed to room temperature and stirred for 2 hours before solvent was concentrated under reduced pressure. Product 38 from step $1(30 \mu \mathrm{mol})$ was added in $1 \mathrm{~mL}$ DMF followed by DIPEA $(20 \mu \mathrm{L})$. Reaction was stirred overnight, concentrated under reduced pressure and purified via HPLC affording $7 \mathrm{mg} \mathrm{(24 \% )}$ of desired product Piv-PHICS3 as an off-white solid. ${ }^{1} \mathrm{H}$ NMR (400 MHz, $\mathrm{CDCl}_{3} / \mathrm{CD}_{3} \mathrm{OH}$ 1:1): 8.61 (br s, 1H), 7.98 (br s 1H), 7.87 (br s, 1H), 7.55-7.67 (m, 2H), 7.43-7.50 (m, 1H), 7.34-7.24 (m, 4H), 7.11-7.08 (m, 1H), 7.04-6.97 (m, 4H), $6.85(\mathrm{~m}, 2 \mathrm{H}), 4.90-4.77(\mathrm{~m}, 1 \mathrm{H}), 4.59-4.48(\mathrm{~m}, 1 \mathrm{H}), 4.32-4.19(\mathrm{~m}, 1 \mathrm{H})$, 4.09-3.99 (m, 2H), 3.58-3.50 (m, 2H), 3.29-3.24 (m, 2H), 2.35-2.26 (m, 2H), 2.22-2.10 (m, 3H), 2.03-1.90 (m, 1H), $1.67-1.46(\mathrm{~m}, 5 \mathrm{H}), 1.31-1.17(\mathrm{~m}, 10 \mathrm{H}), 1.07(\mathrm{~s}, 9 \mathrm{H}) .{ }^{13} \mathrm{C} \mathrm{NMR}\left(100 \mathrm{MHz}, \mathrm{CDCl}_{3} / \mathrm{CD}_{3} \mathrm{OH} 1: 1\right): 174.68$ $172.42,157.74,157.35,156.07,153.97,152.76,133.62,133.07,132.79,132.56,130.25,129.39,129.10$ $127.97,126.47,124.75,123.10,122.46,118.49,117.79,113.03,111.83,65.70,52.95,52.12,49.12,45.14$ $44.90,41.14,38.29,35.21,32.46,29.01,28.76,28.42,28.17,25.64,25.07,24.61,23.97,22.88$ ppm. HRMS (ESI-TOF): calculated for $\mathrm{C}_{54} \mathrm{H}_{60} \mathrm{CIN}_{8} \mathrm{O}_{7}(\mathrm{M}+\mathrm{H}): 967.4268$, found: 967.4265 . 


\section{Characterization of compounds: ${ }^{1} \mathrm{H}$ and ${ }^{13} \mathrm{C}$ NMR spectra}

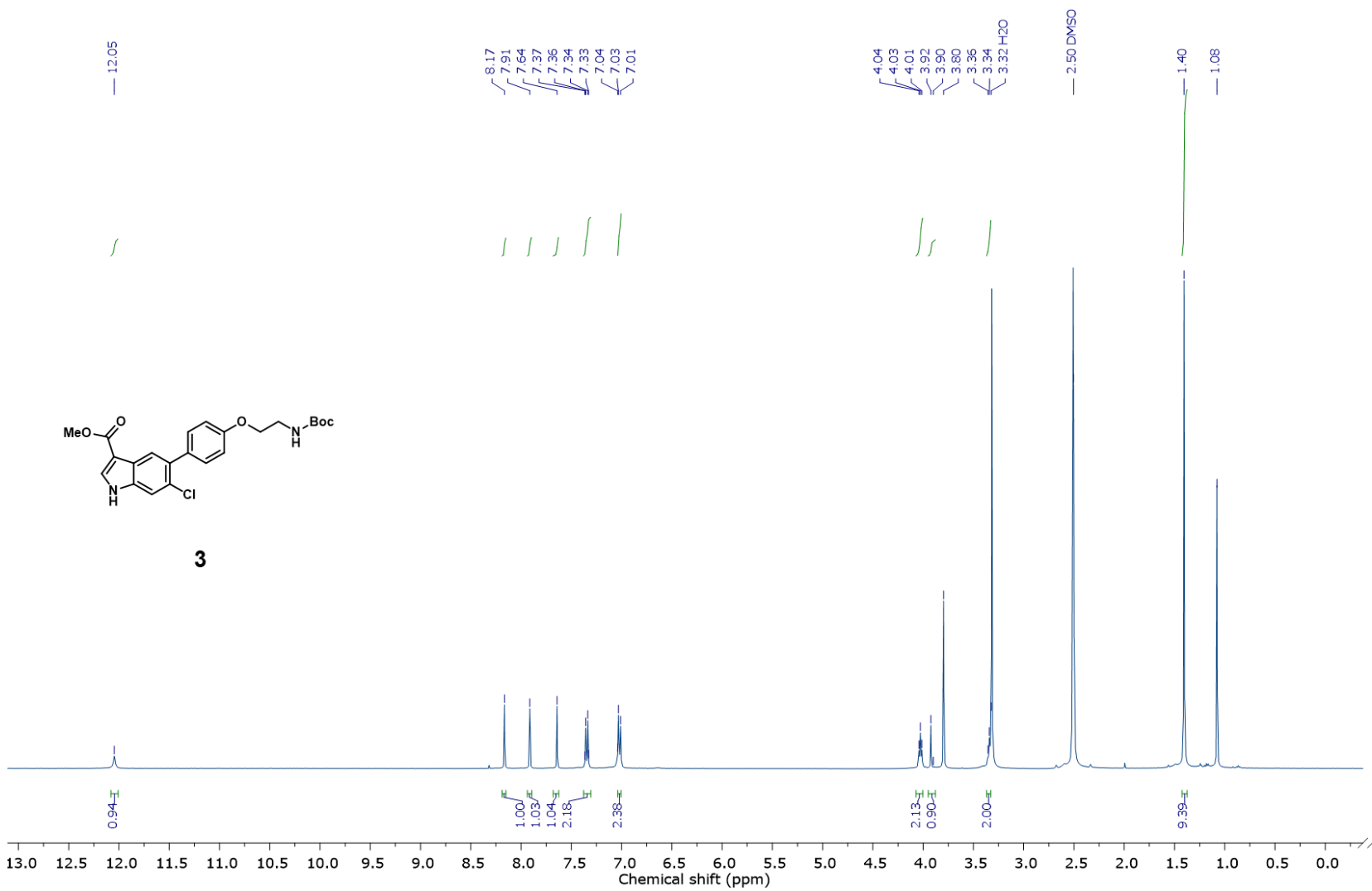

Figure S18. ${ }^{1} \mathrm{H}$ NMR spectrum of 3.

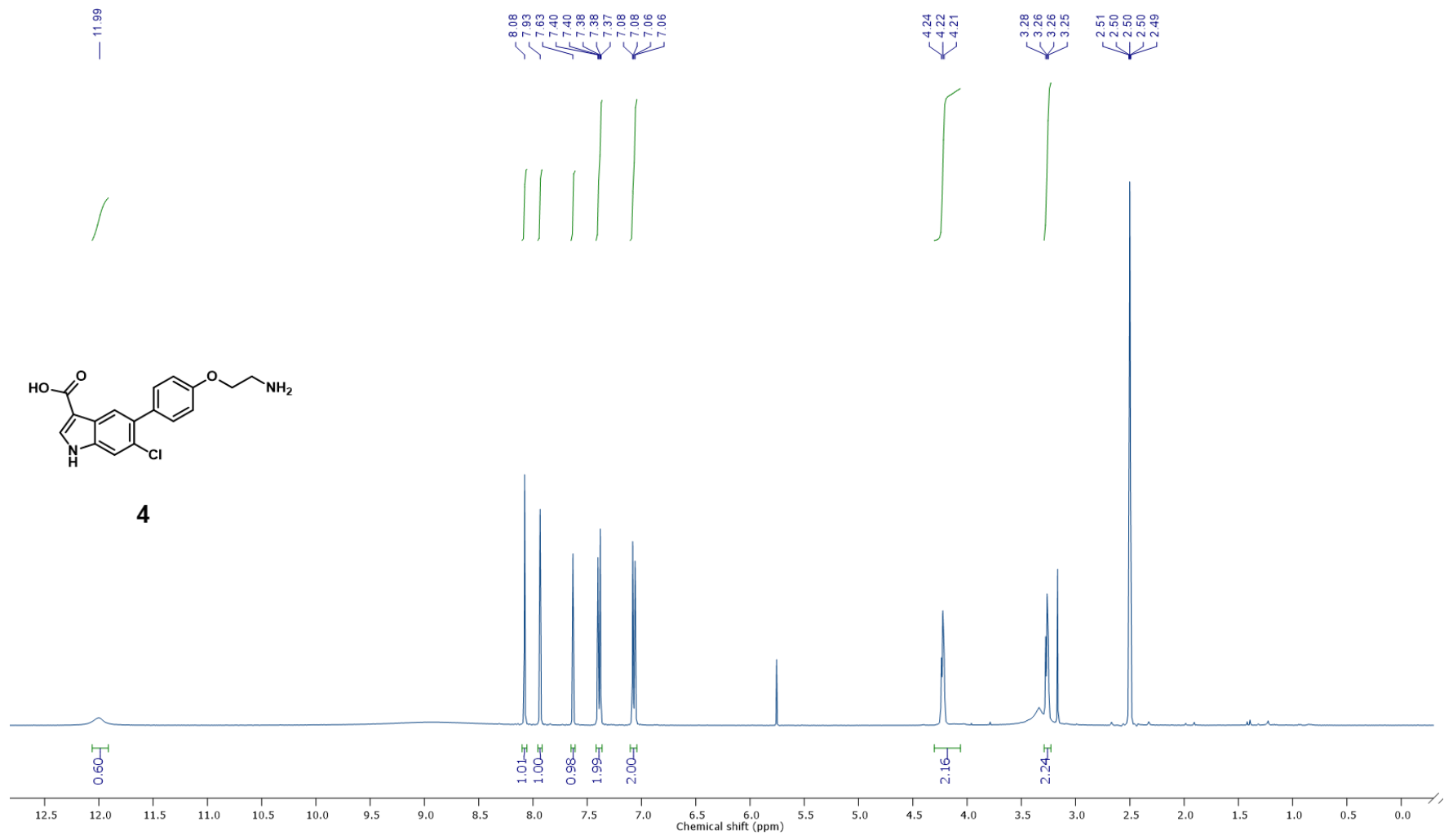

Figure S19. ${ }^{1} \mathrm{H}$ NMR spectrum of 4 . 


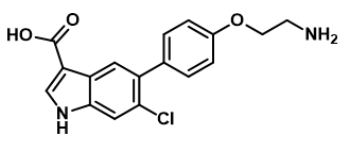

4
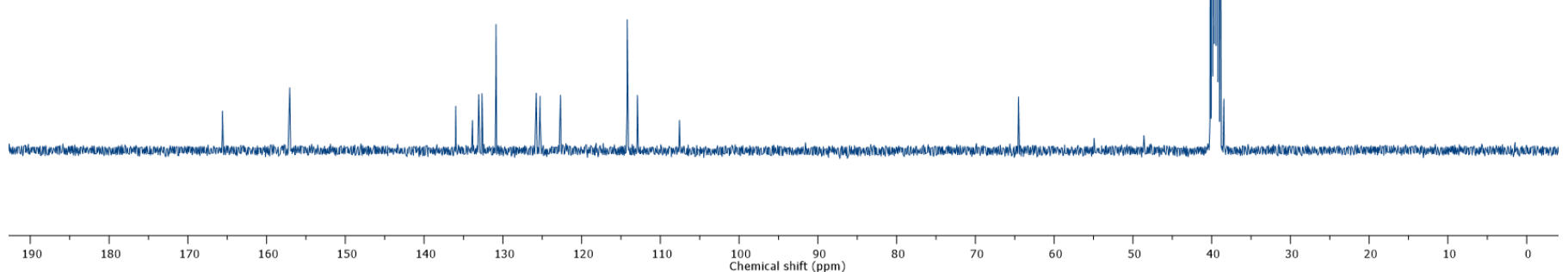

Figure S20. ${ }^{13} \mathrm{C}$ NMR of 4 .

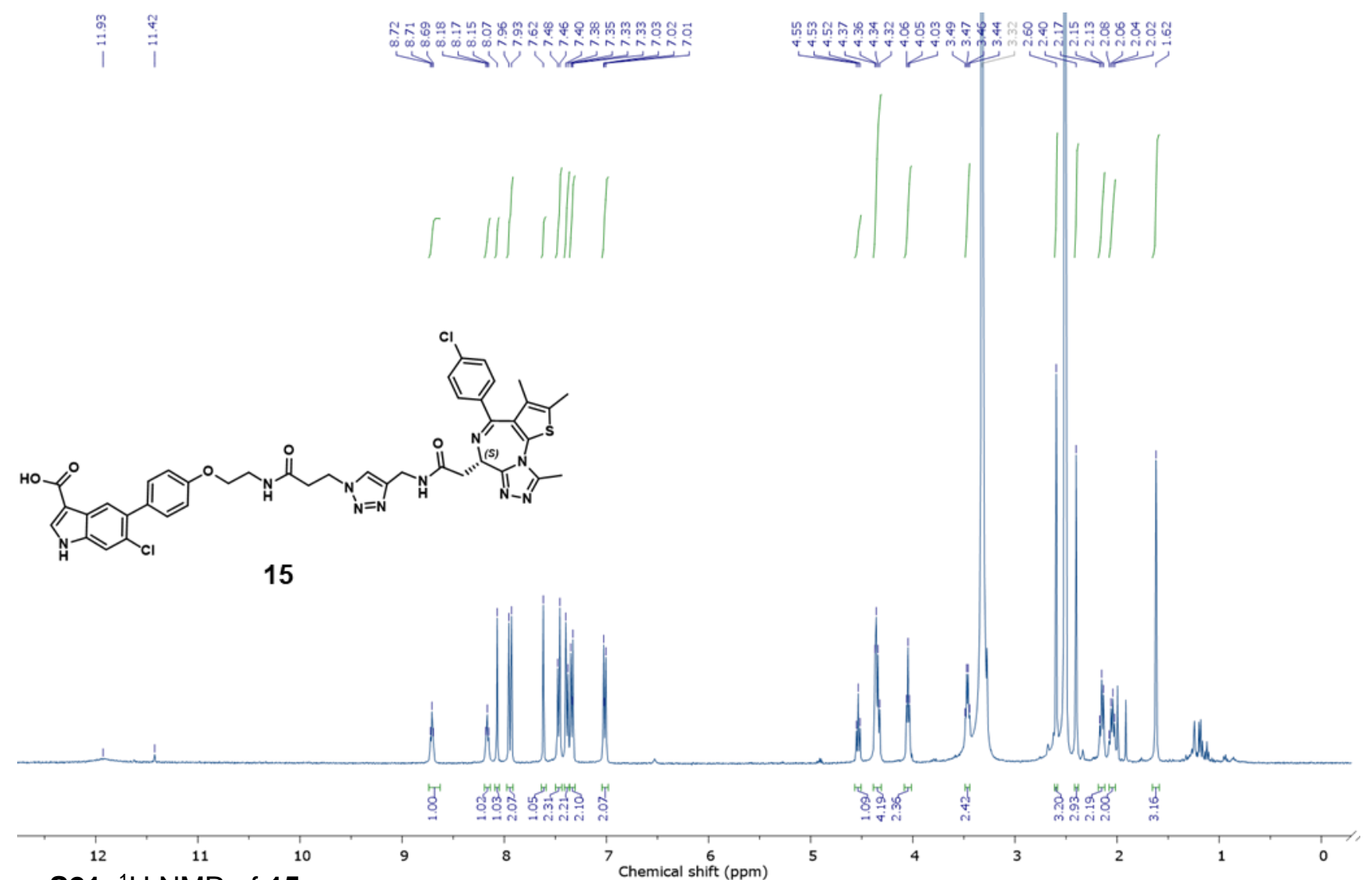

Figure S21. ${ }^{1} \mathrm{H}$ NMR of 15. 

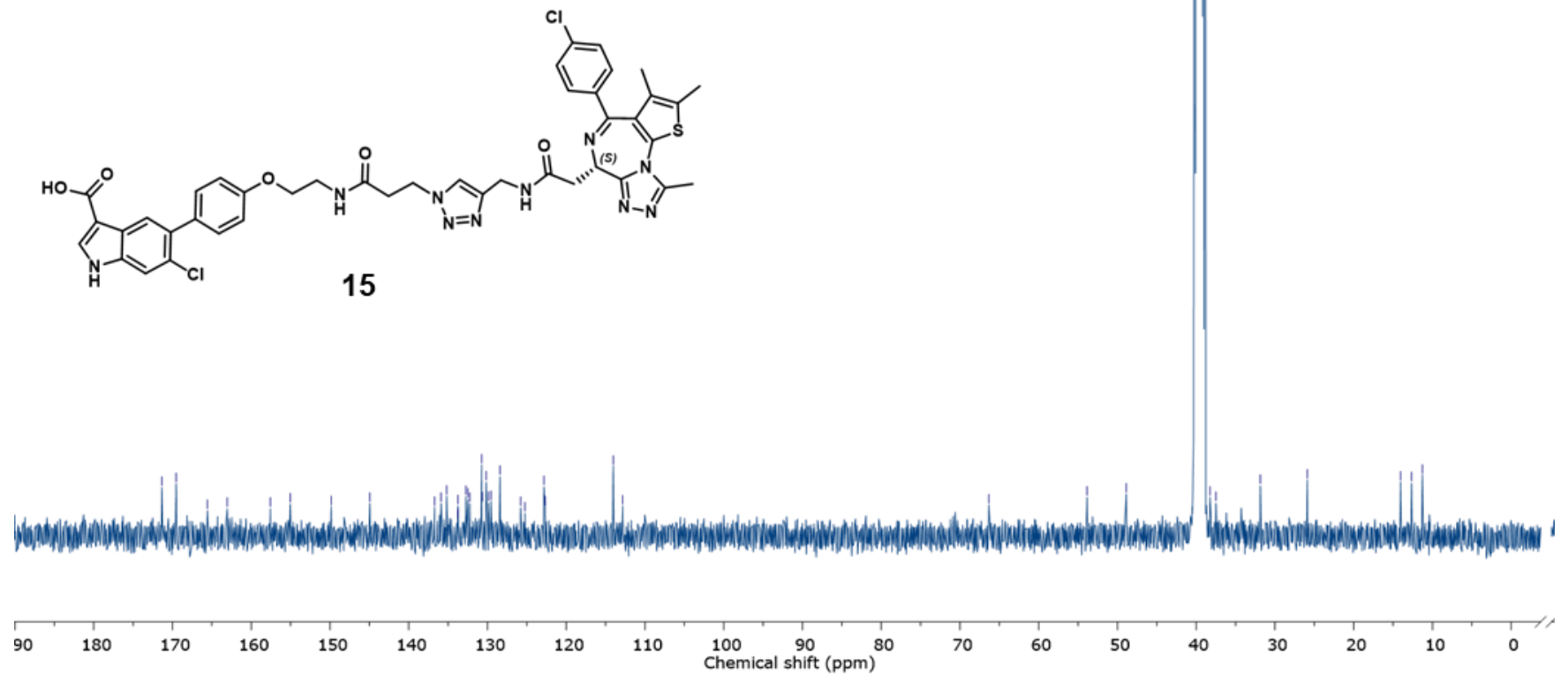

Figure S22. ${ }^{13} \mathrm{C}$ NMR of 15.

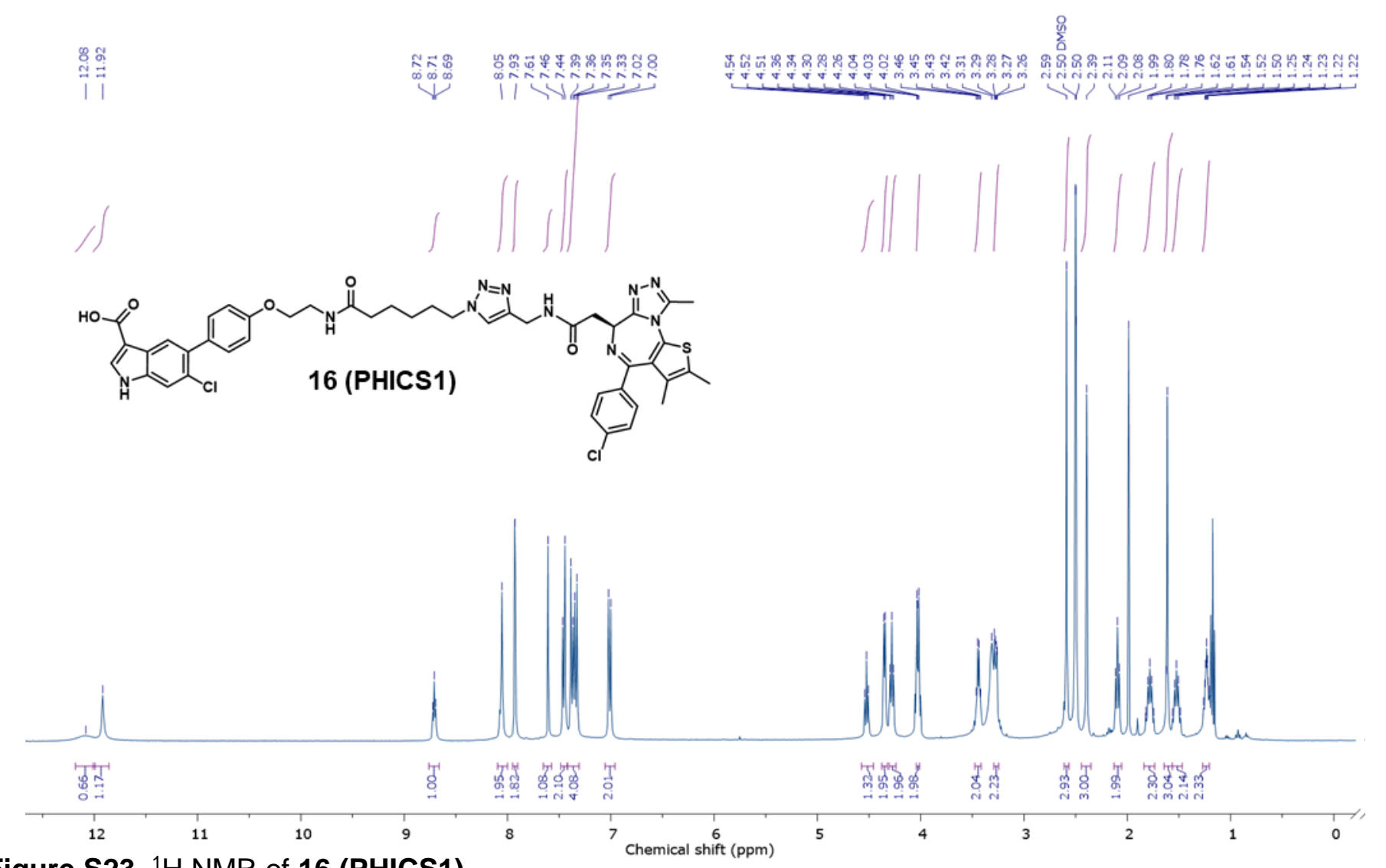

Figure S23. ${ }^{1} \mathrm{H}$ NMR of 16 (PHICS1). 

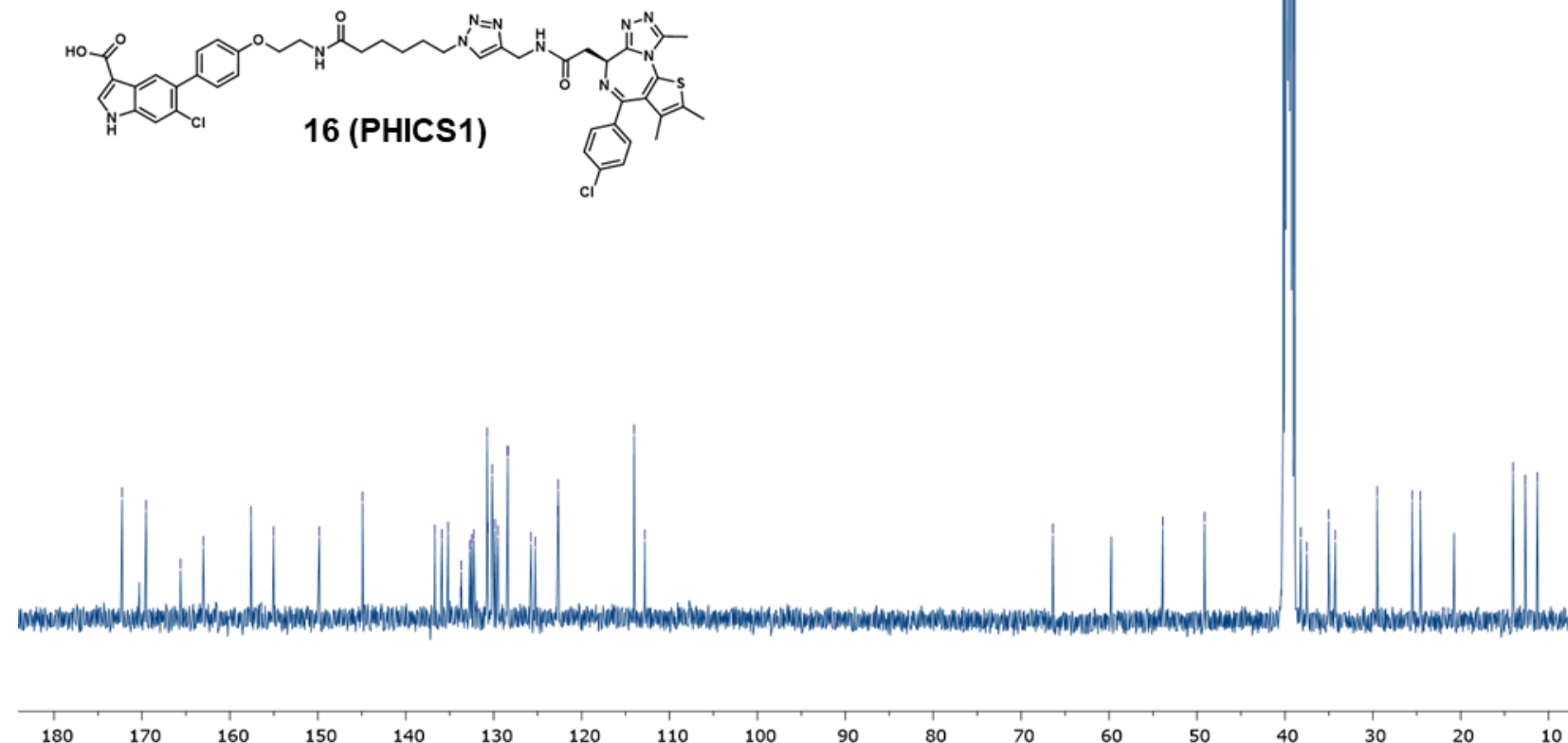

Figure S24. ${ }^{13} \mathrm{C}$ NMR of 16 (PHICS1).

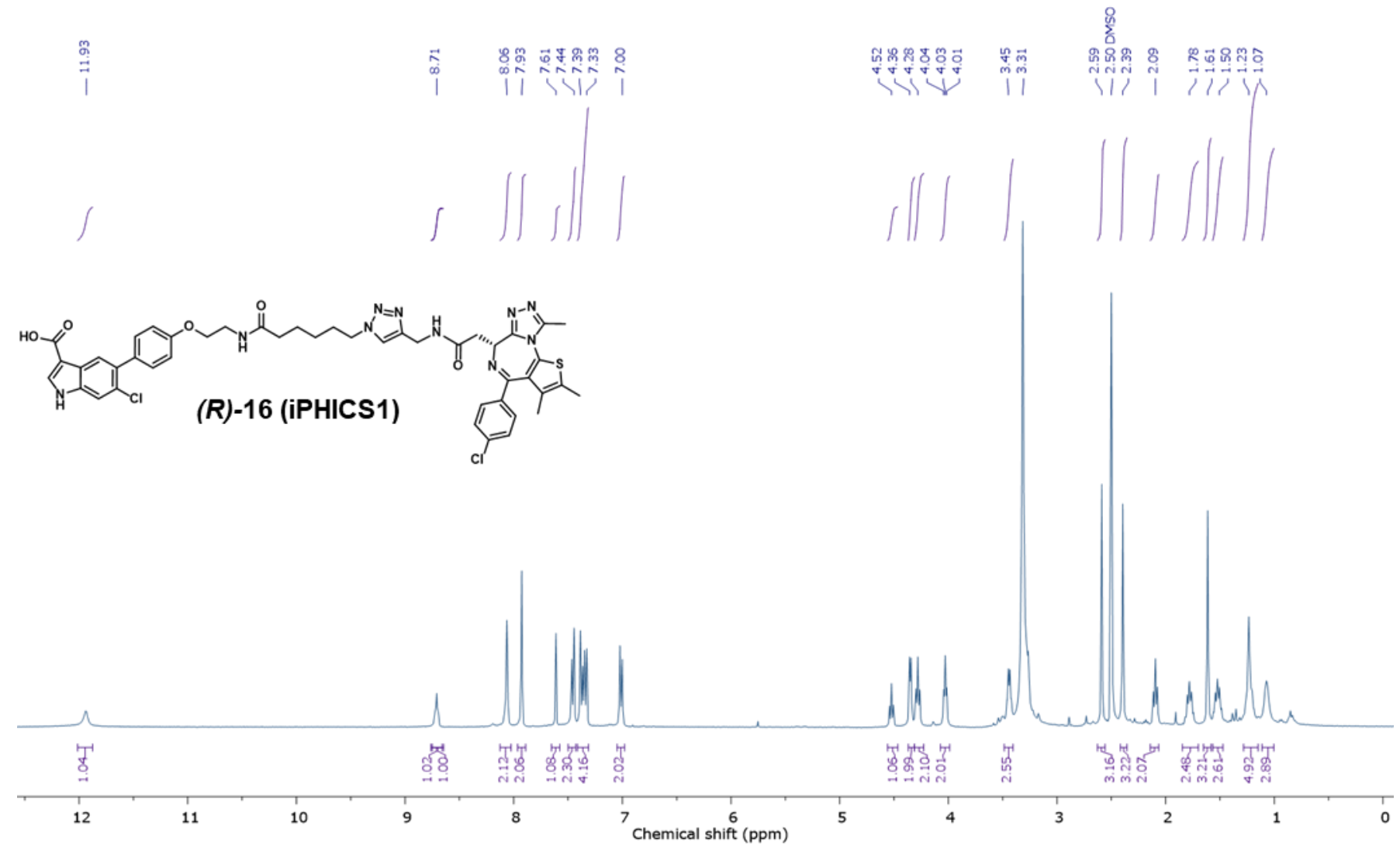

Figure S25. ${ }^{1} \mathrm{H}$ NMR of (R)-16 (iPHICS1). 


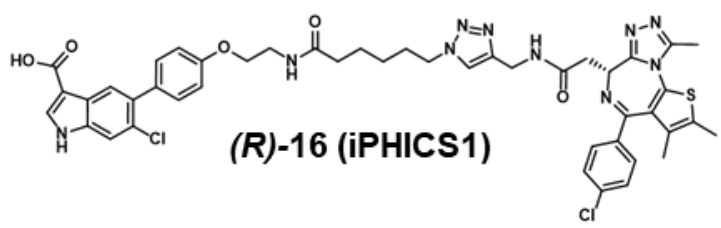

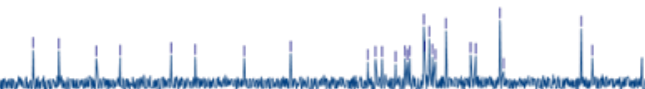

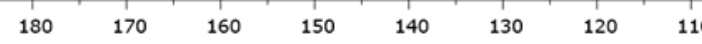

Figure S26. ${ }^{13} \mathrm{C}$ NMR of (R)-16 (iPHICS1).

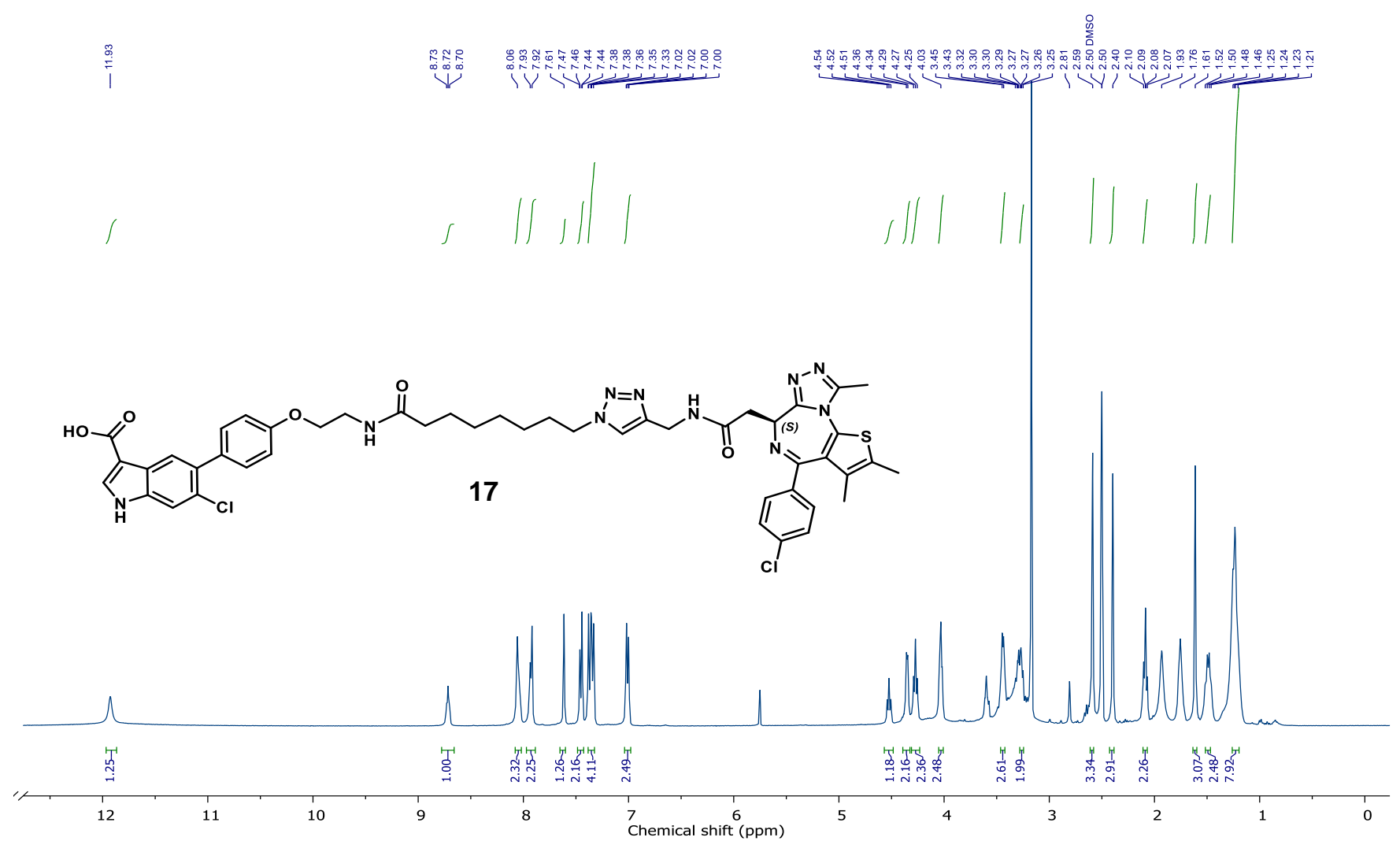

Figure S27. ${ }^{1} \mathrm{H}$ NMR of 17 

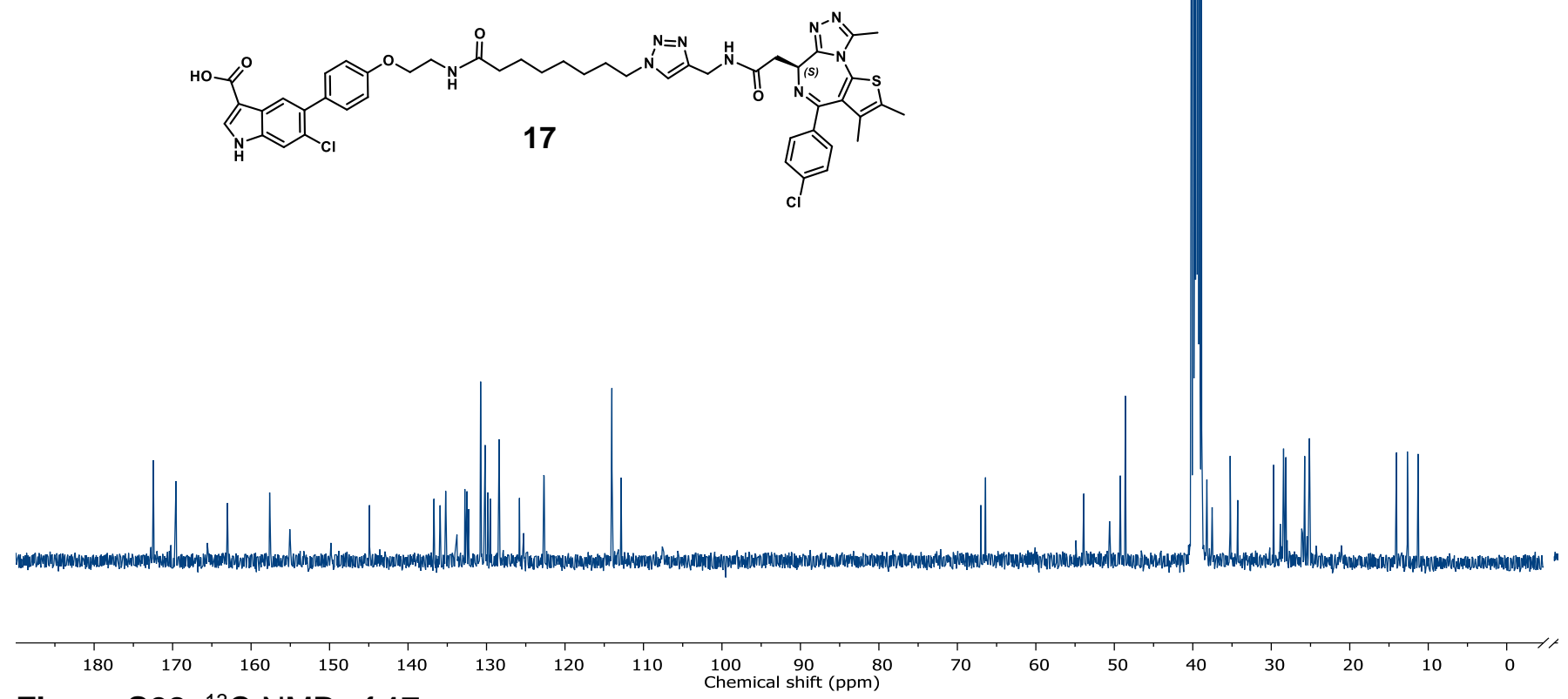

Figure S28. ${ }^{13} \mathrm{C}$ NMR of 17.

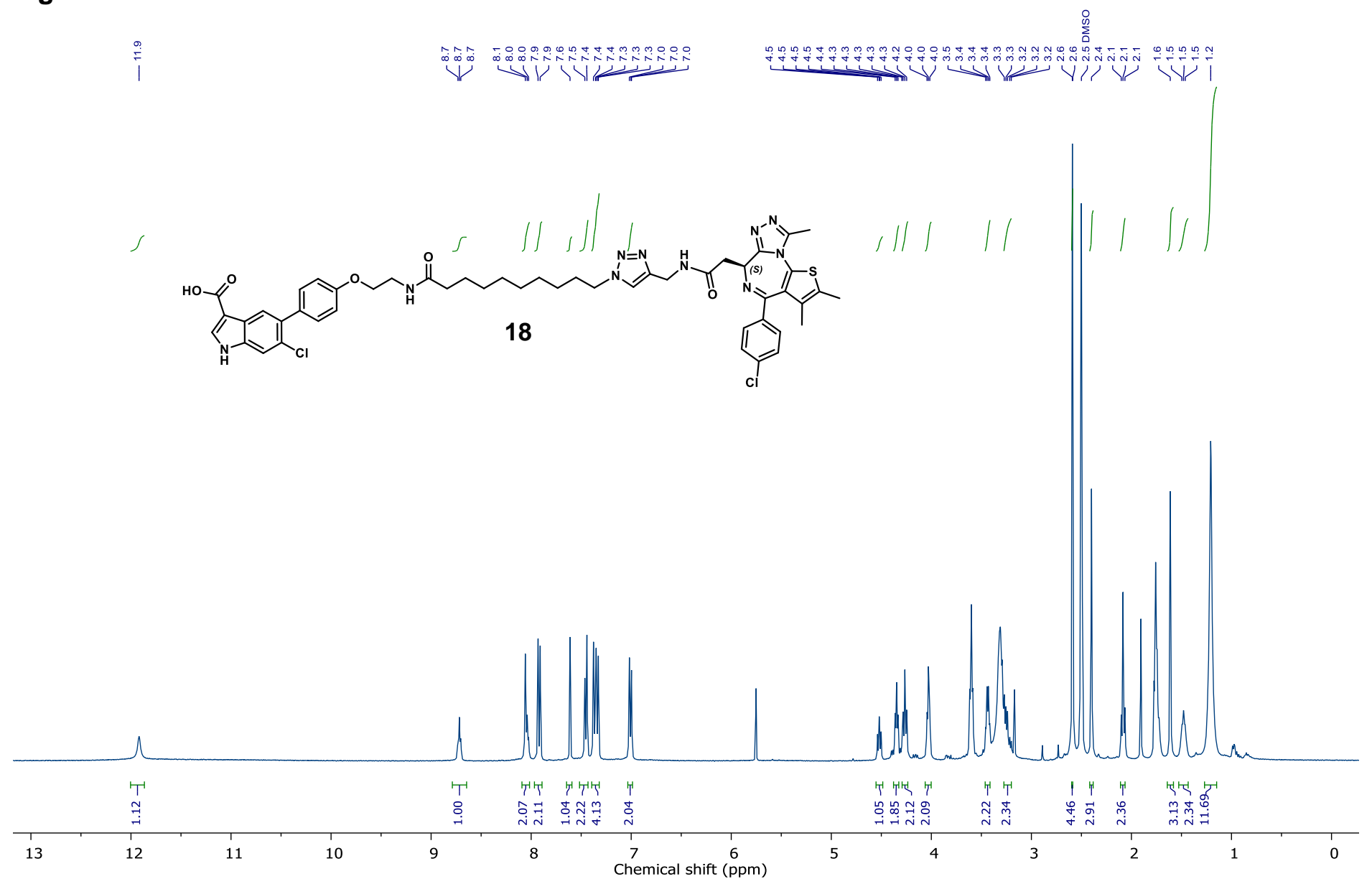

Figure S29. ${ }^{1} \mathrm{H}$ NMR of 18. 
|

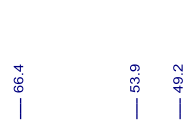
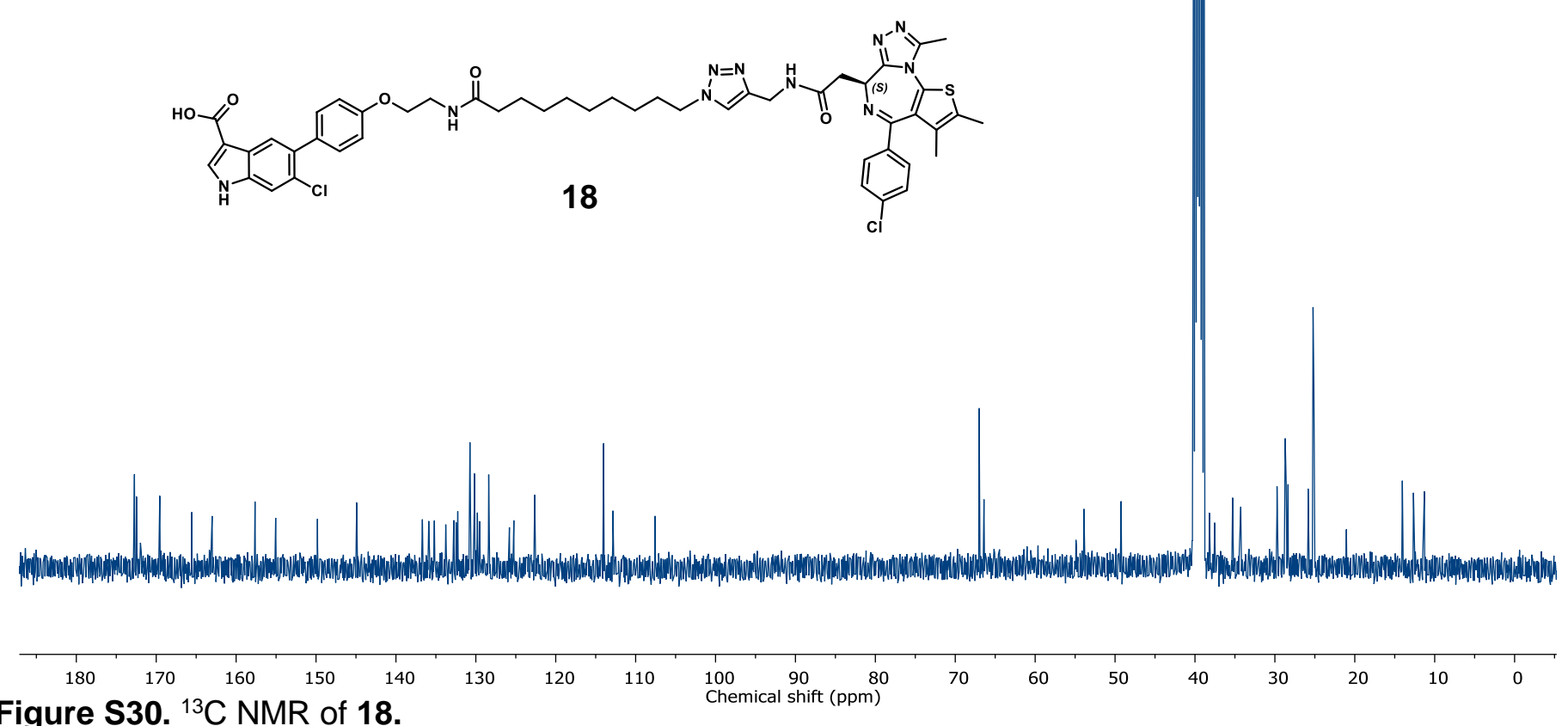

Figure S30. ${ }^{13} \mathrm{C}$ NMR of 18.

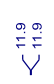

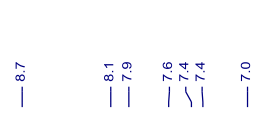

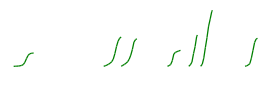

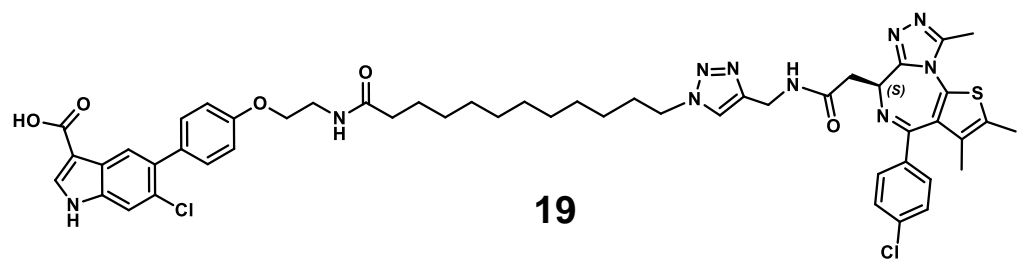

19

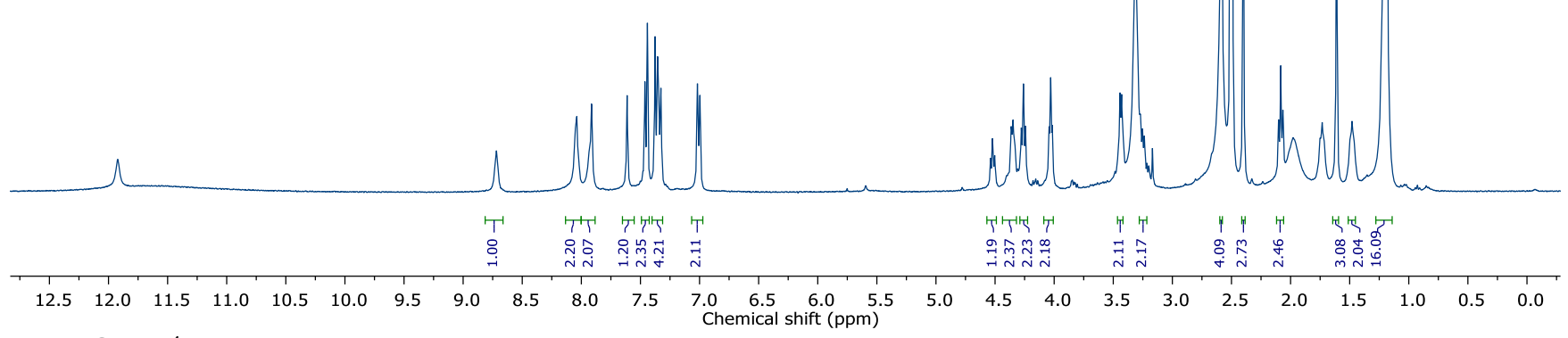

Figure S31. ${ }^{1} \mathrm{H}$ NMR of 19.

49 
<smiles>Cc1sc2c(c1C)C(c1ccc(Cl)cc1)=N[C@@H](CC(=O)NCc1cn(CCCCCCCCCCCC(=O)NCCOc3ccc(-c4cc5c(C(=O)O)c[nH]c5cc4Cl)cc3)nn1)c1nnc(C)n1-2</smiles>
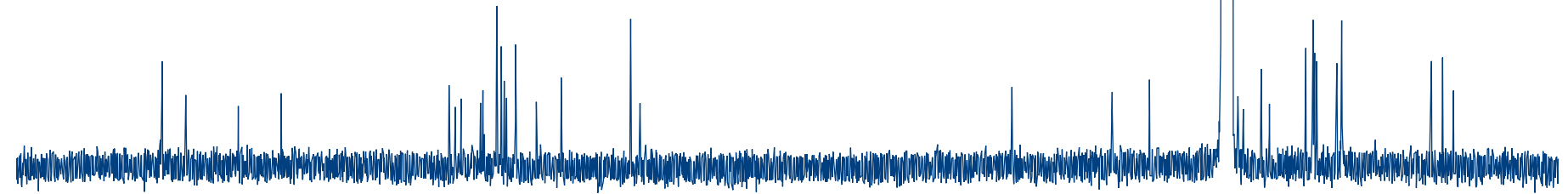

Figure S32. ${ }^{13} \mathrm{C}$ NMR of 19. 
<smiles>CC(=O)N[C@@H](CO)Cc1ccc(OCc2ccc(CNC(=O)OC(C)(C)C)cc2)cc1[N+](=O)[O-]</smiles>

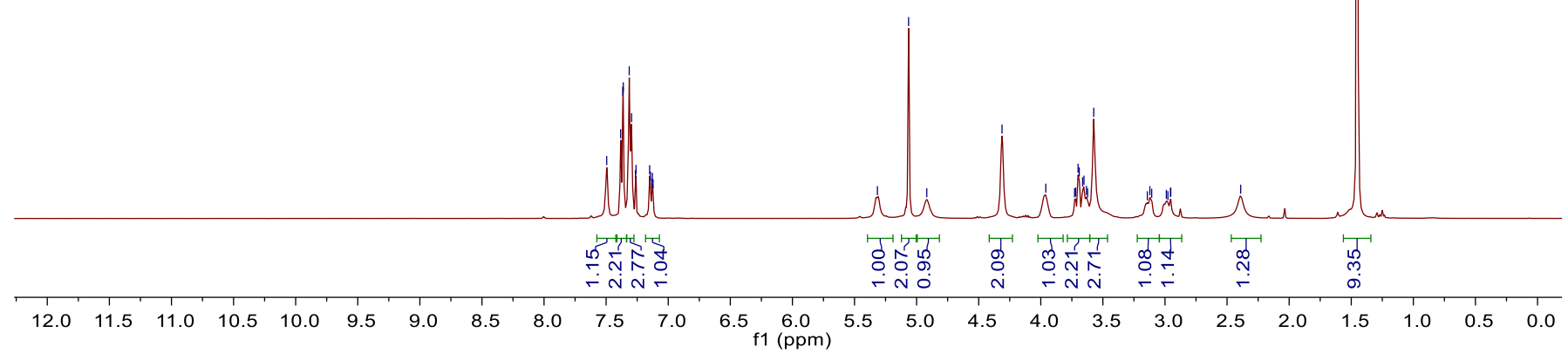

Figure S33. ${ }^{1} \mathrm{H}$ NMR spectrum of 21a.

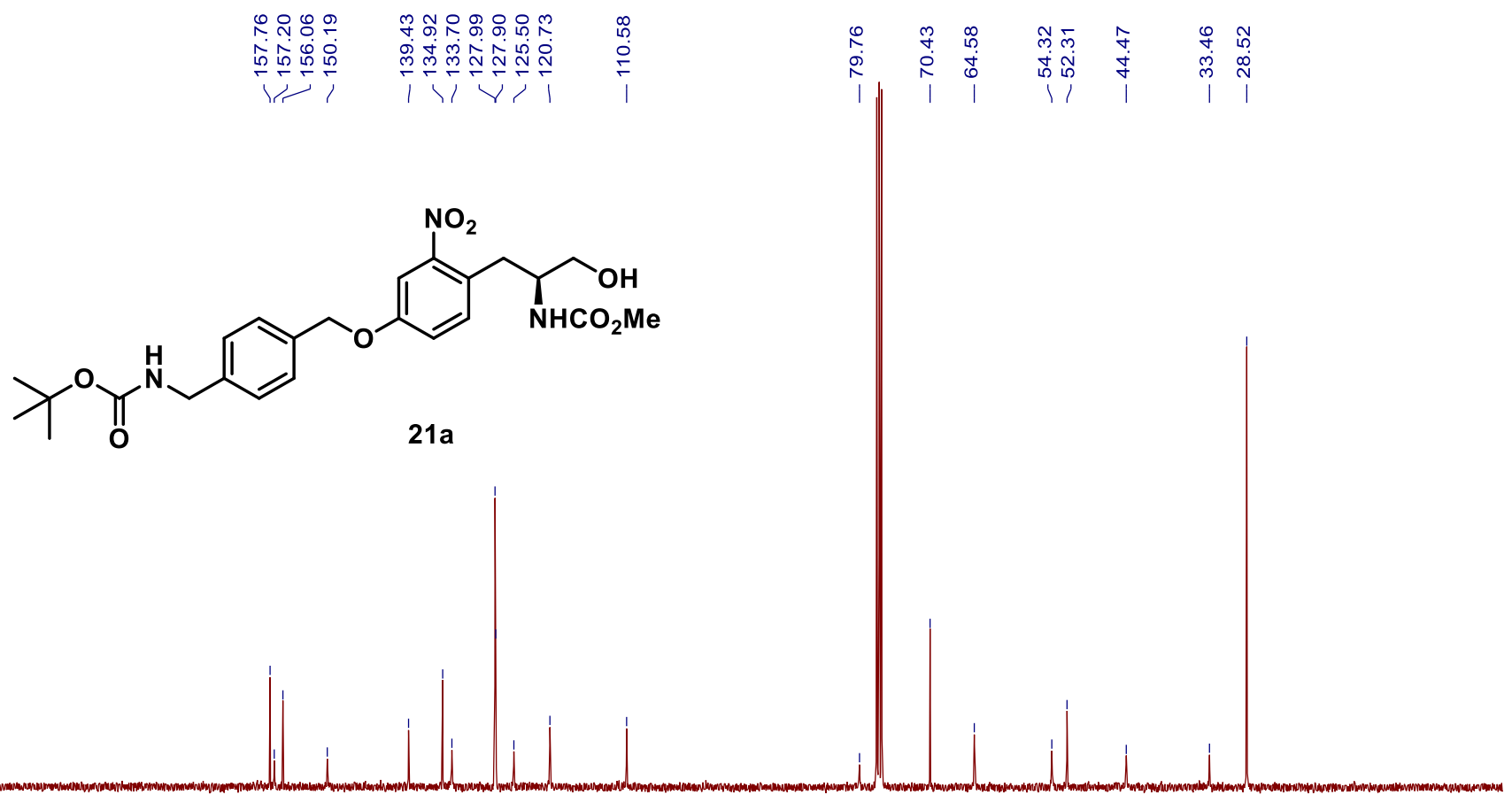

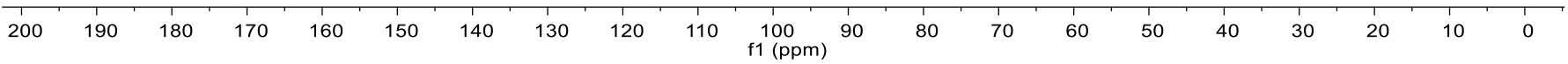

Figure S34. ${ }^{13} \mathrm{CNMR}$ spectrum of $21 \mathrm{a}$. 


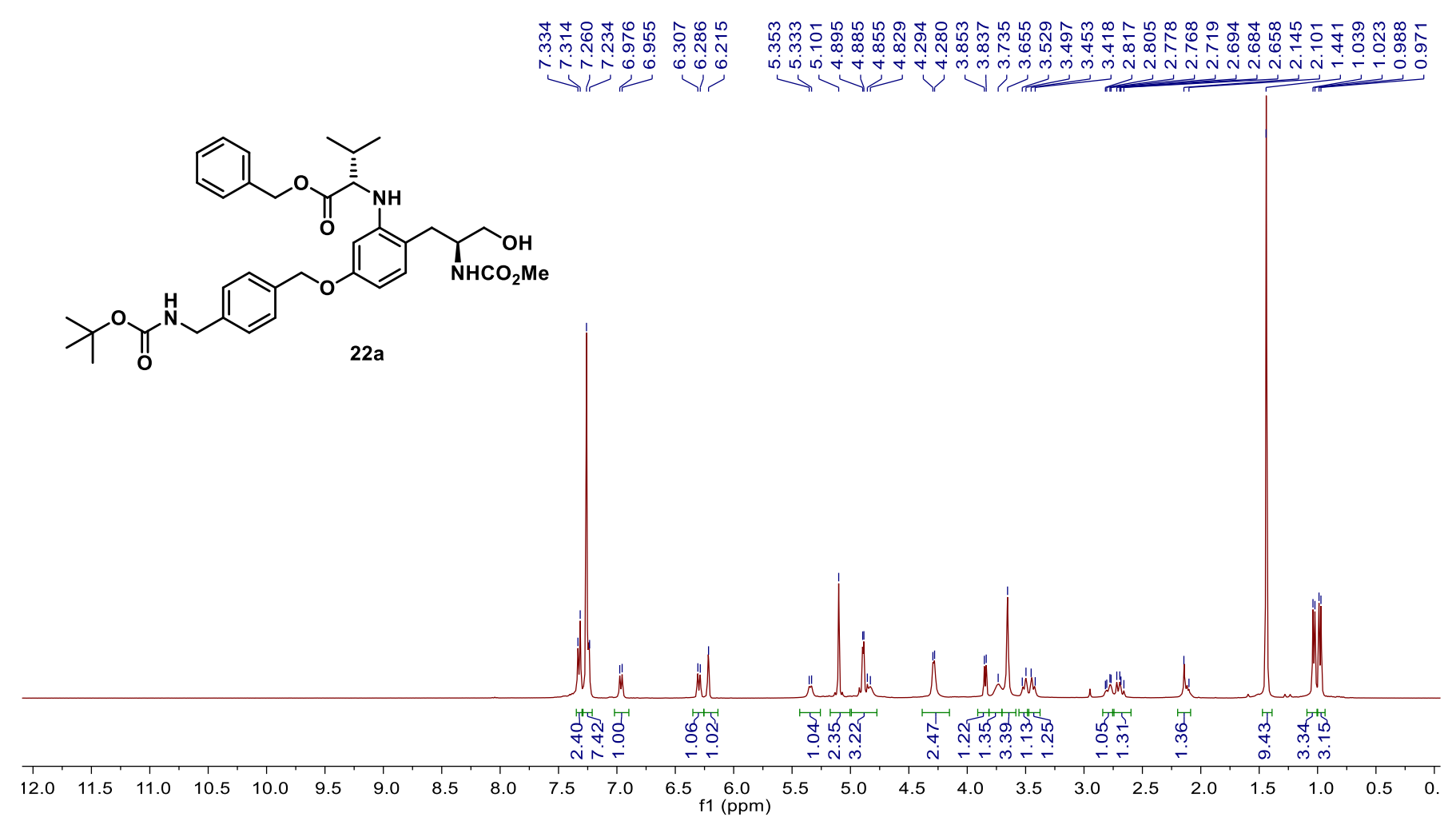

Figure S35. ${ }^{1} \mathrm{H}$ NMR spectrum of $\mathbf{2 2 a}$.
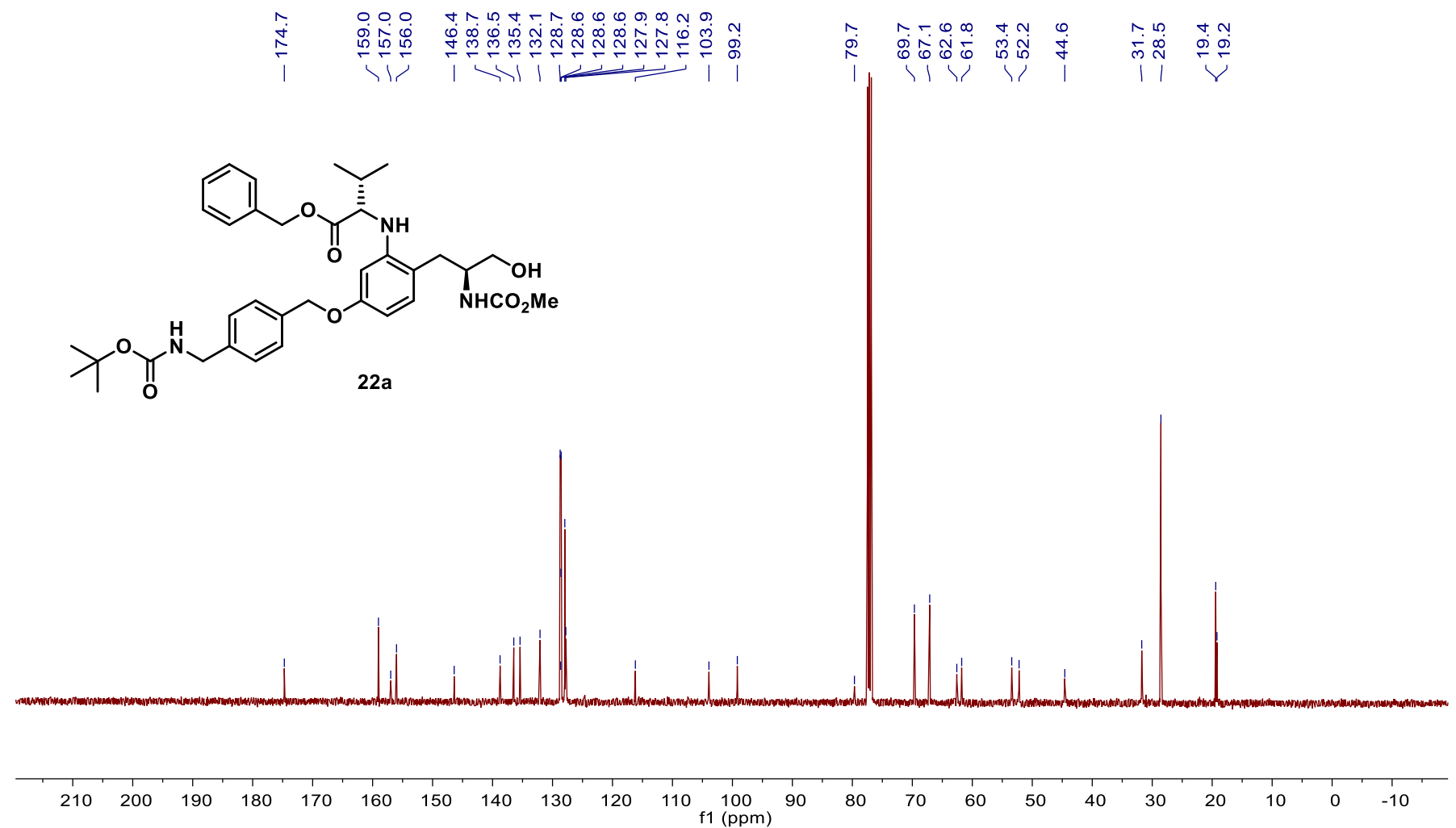

Figure S36. ${ }^{13} \mathrm{C}$ NMR spectrum of $22 a$. 

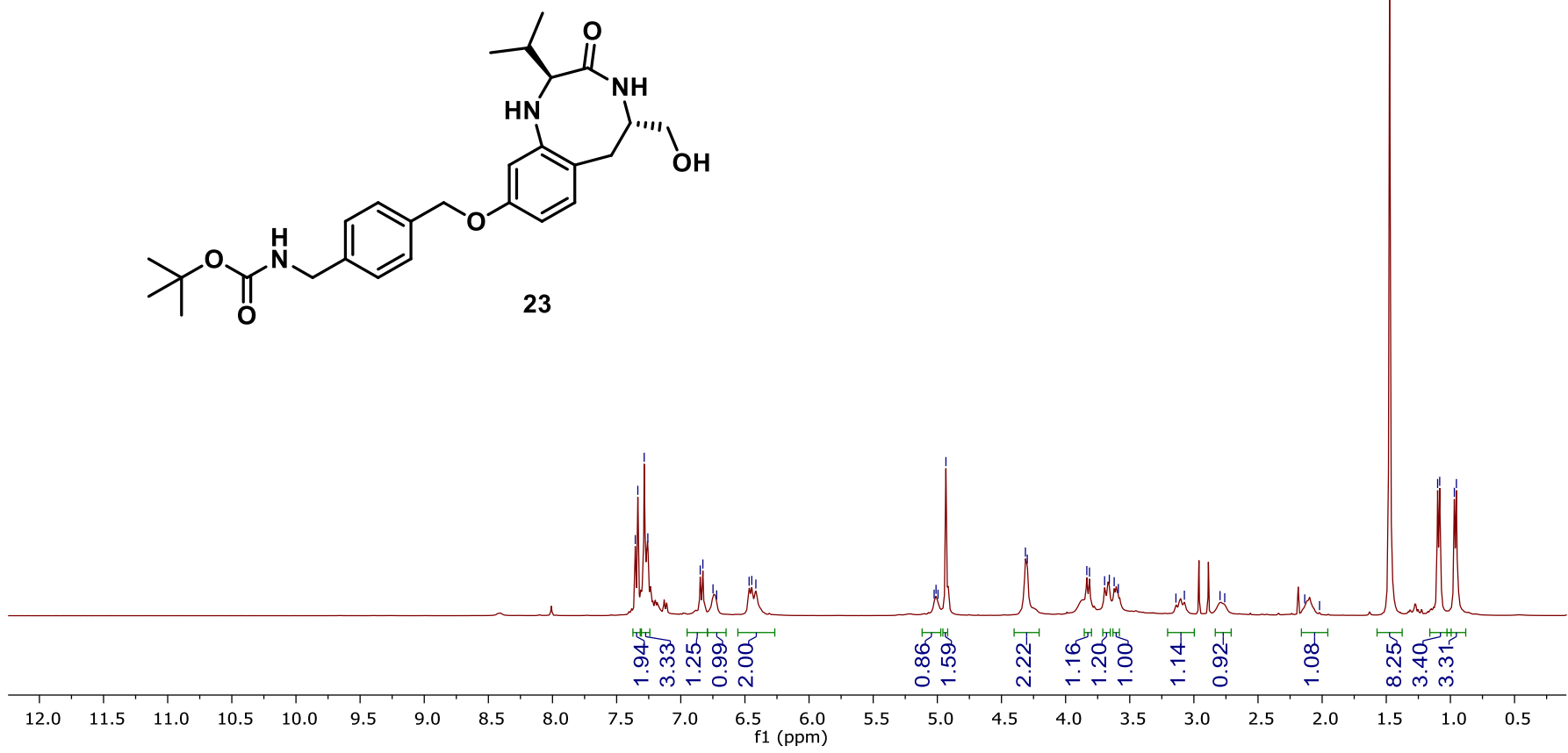

Figure S37. ${ }^{1} \mathrm{H}$ NMR spectrum of 23.
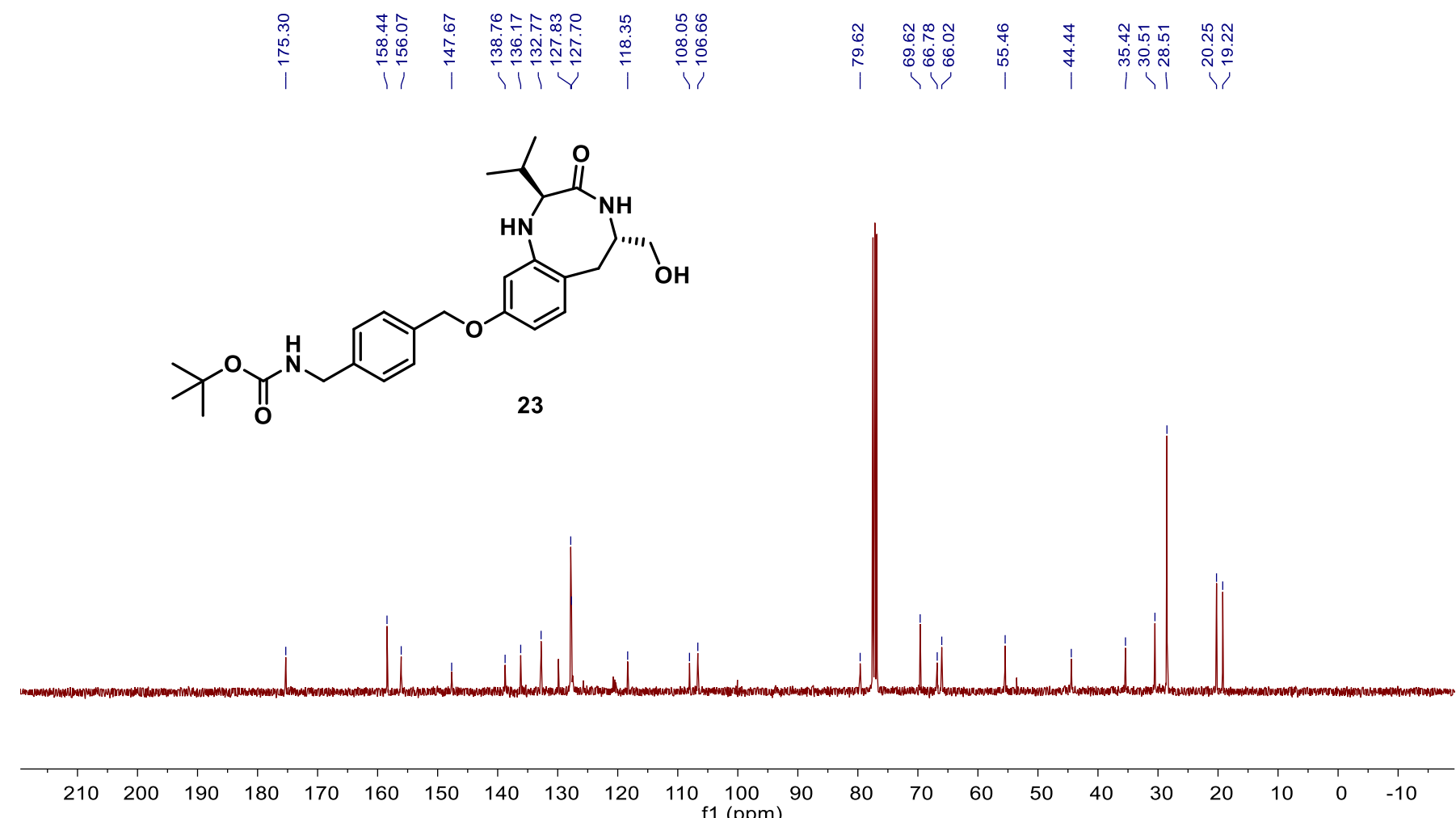

Figure S38. ${ }^{13} \mathrm{C}$ NMR spectrum of 23. 


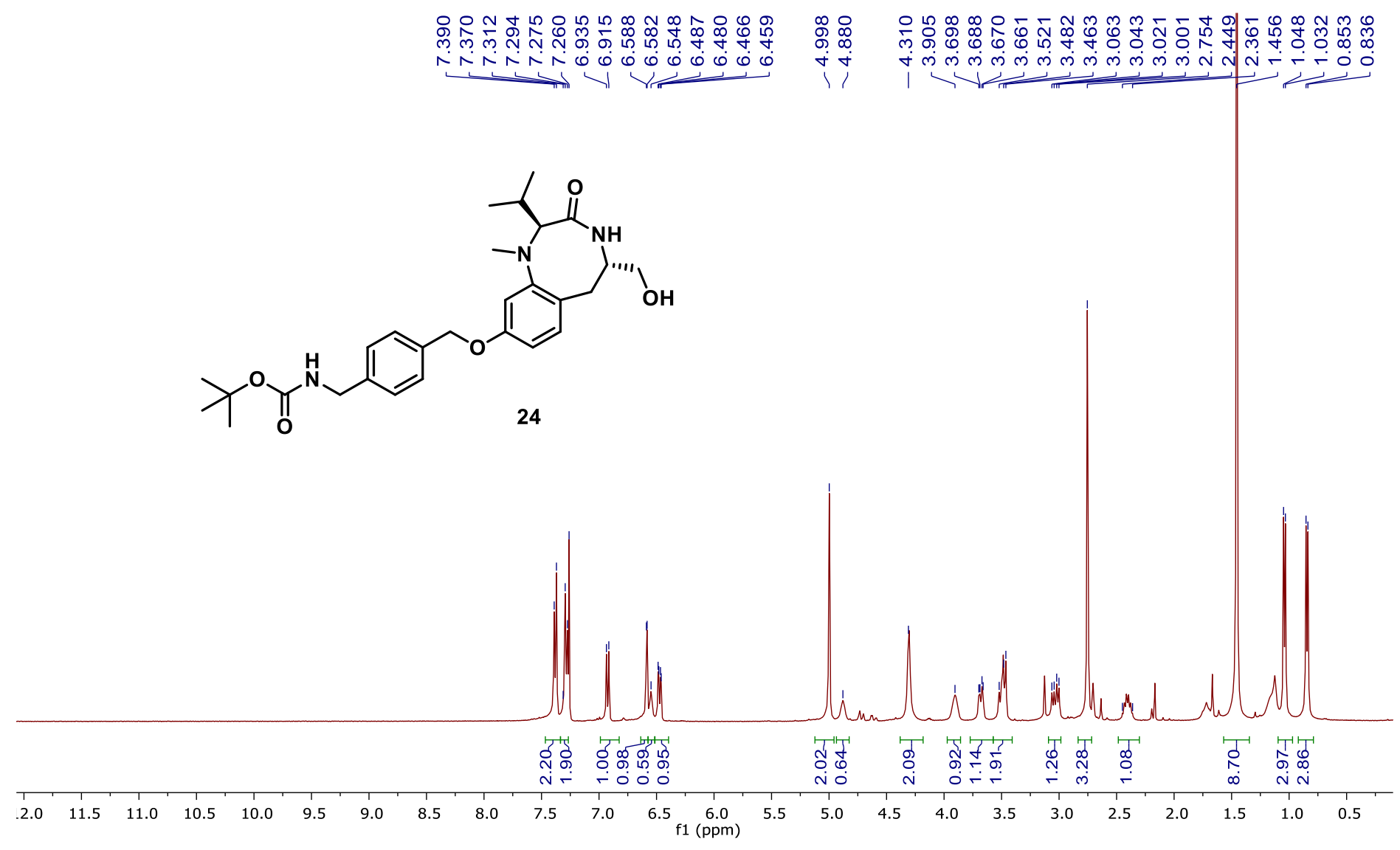

Figure S39. ${ }^{1} \mathrm{H}$ NMR spectrum of 24.
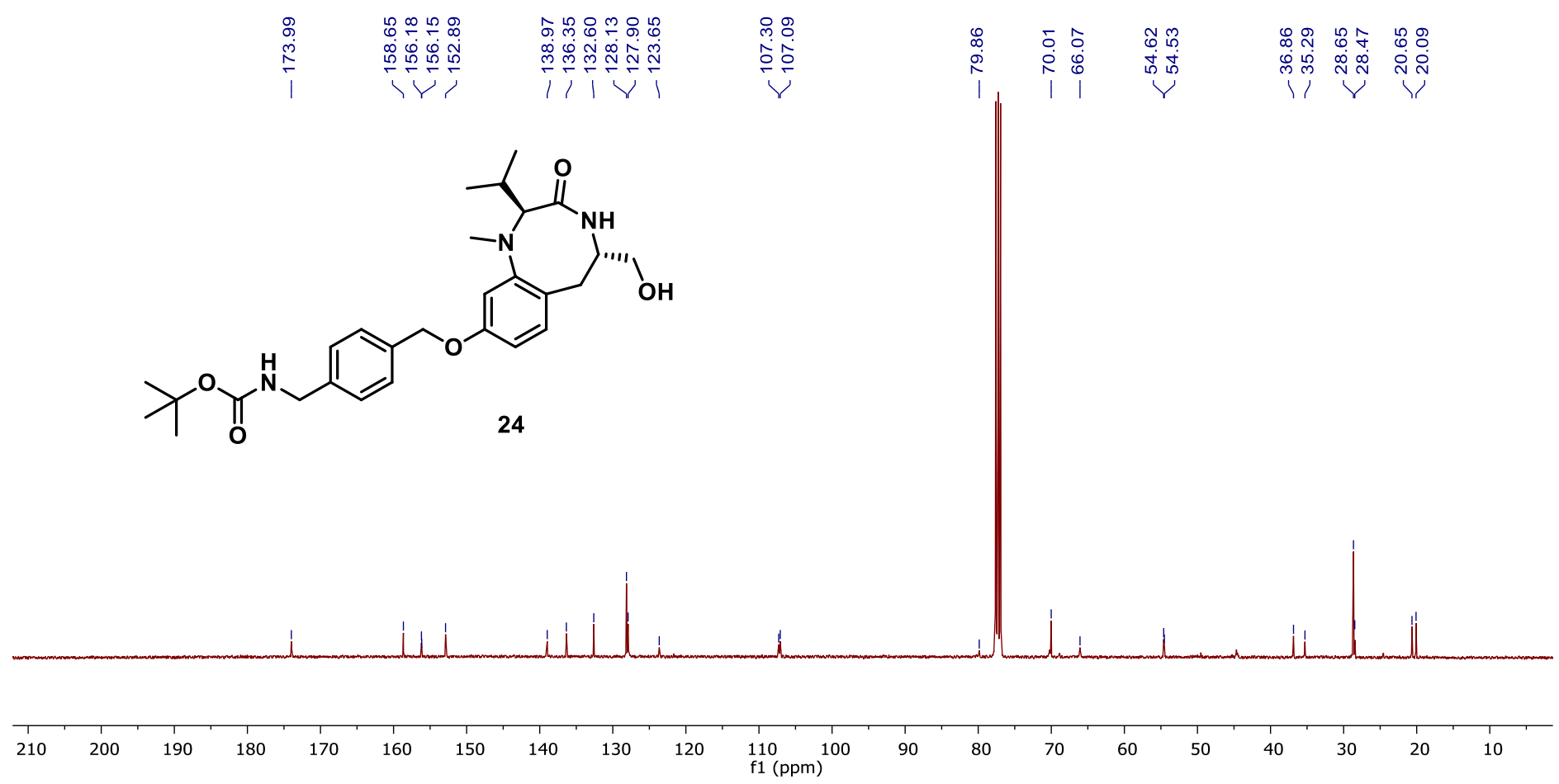

Figure S40. ${ }^{13} \mathrm{C}$ NMR spectrum of 24. 


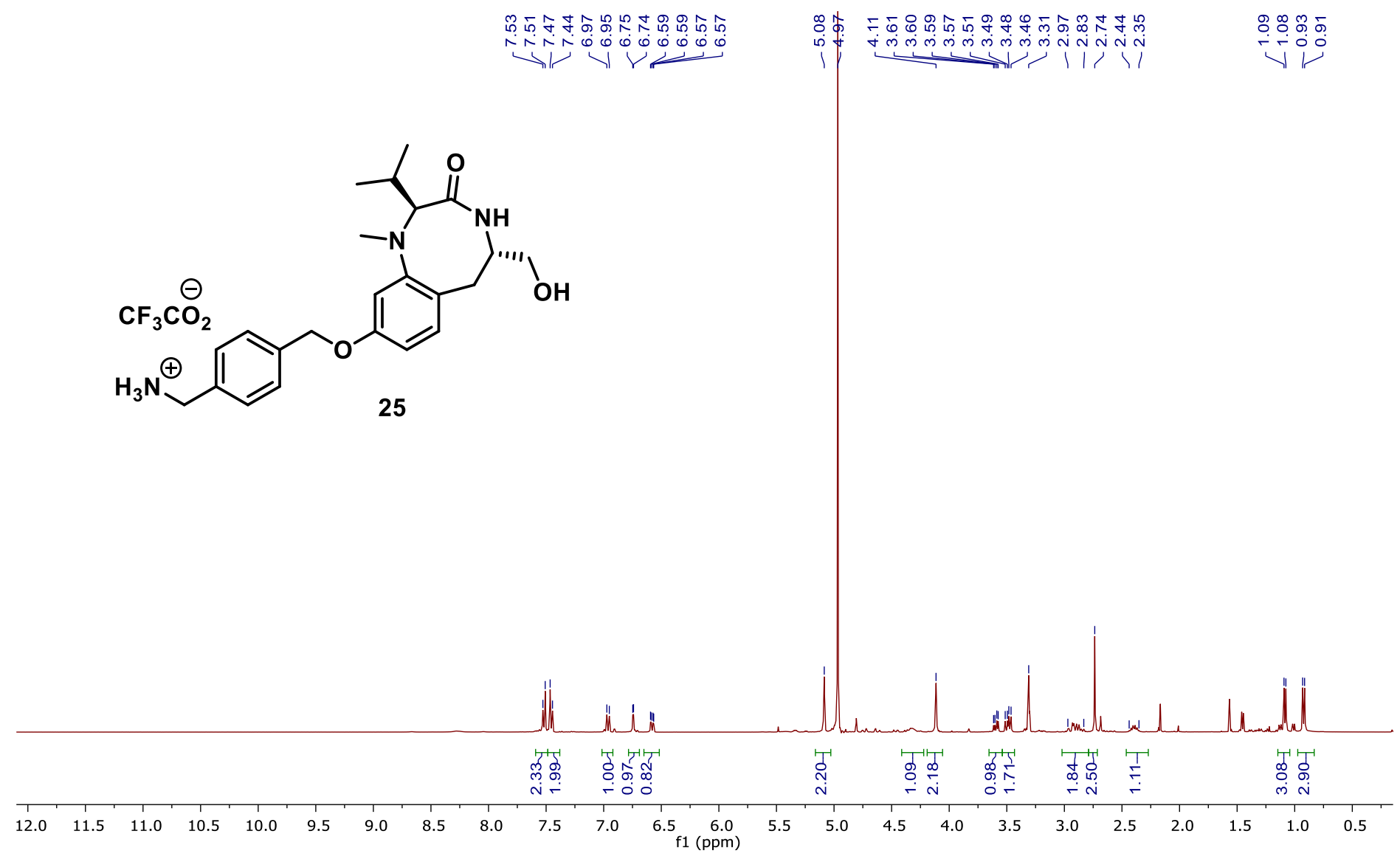

Figure S41. ${ }^{1} \mathrm{H}$ NMR spectrum of 25.

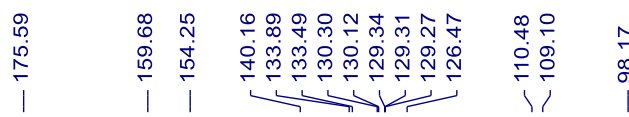

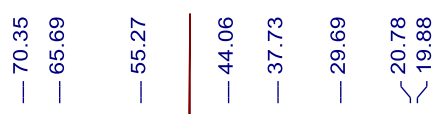<smiles>CC(C)[C@H]1C(=O)N[C@H](CO)Cc2ccc(OCc3ccc(CN)cc3)cc2N1C</smiles>

25

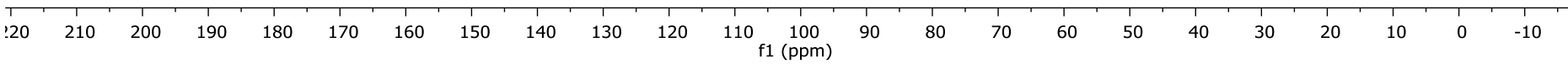

Figure S42. ${ }^{13} \mathrm{C}$ NMR spectrum of 25. 


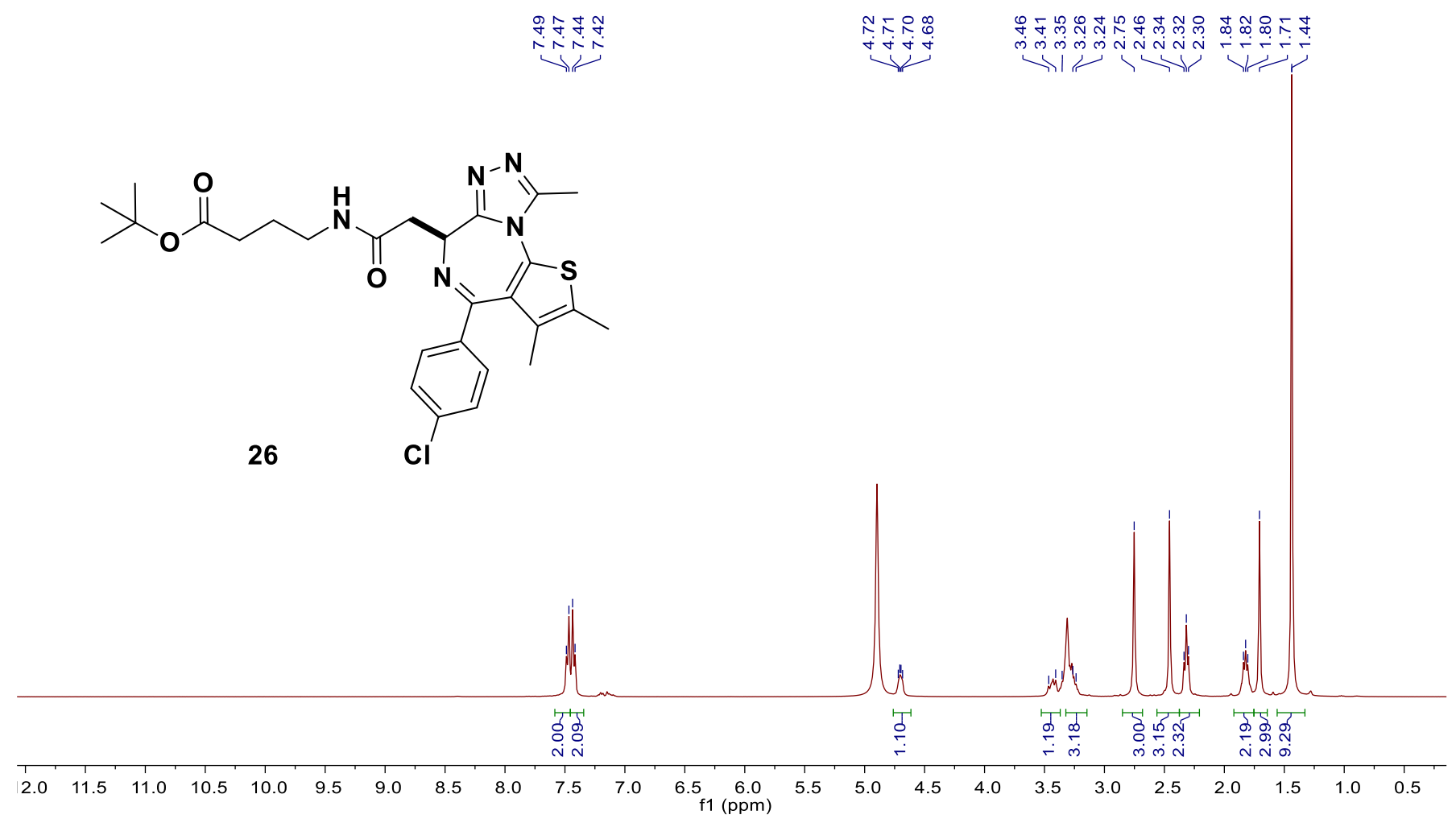

Figure S43. ${ }^{1} \mathrm{H}$ NMR spectrum of 26.

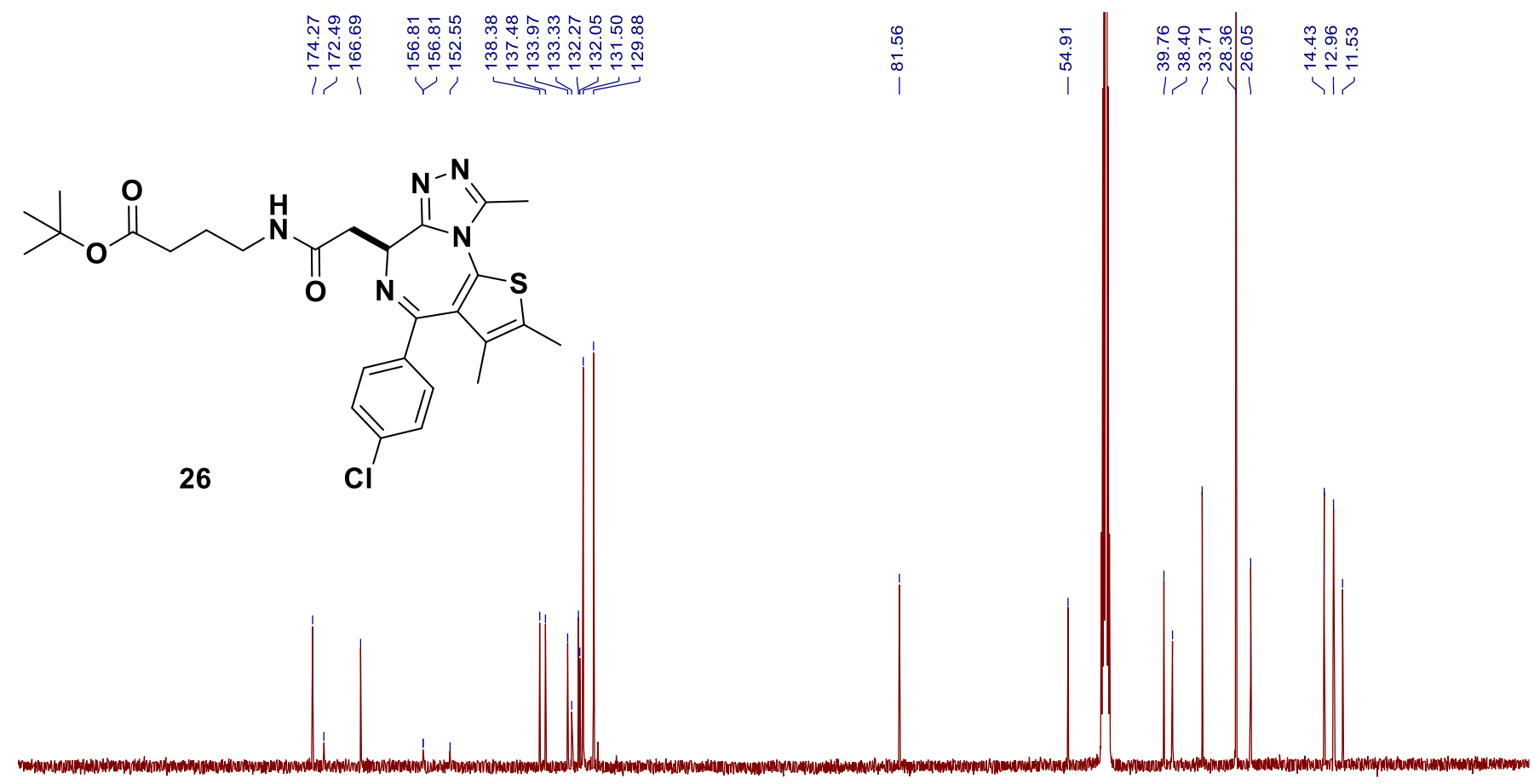

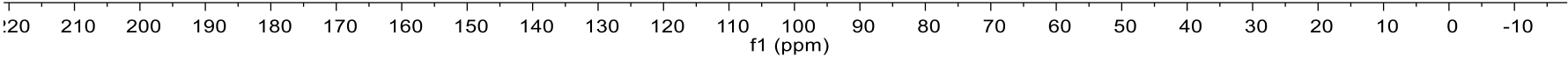

Figure S44. ${ }^{13} \mathrm{C}$ NMR spectrum of 26. 


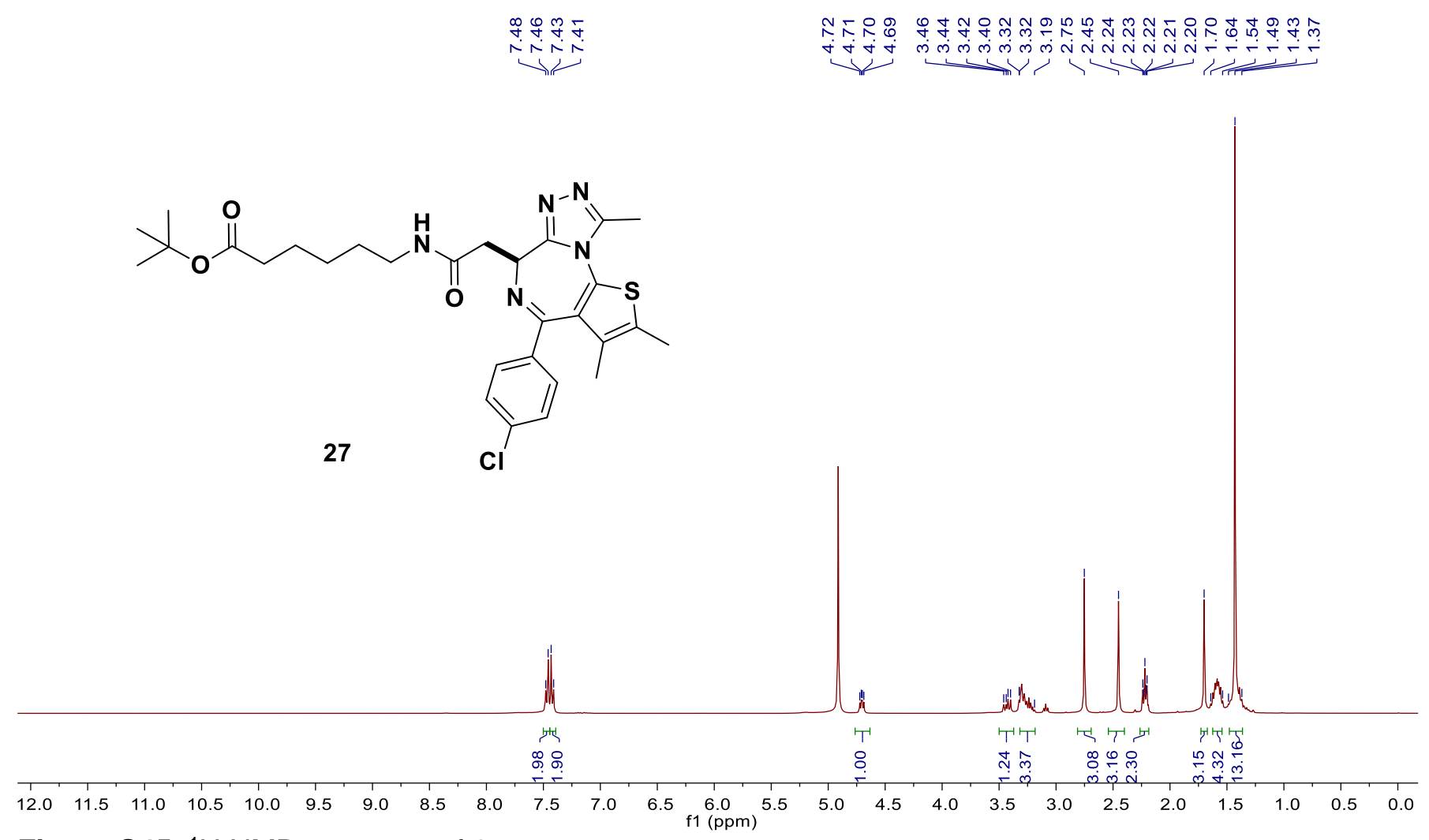

Figure S45. ${ }^{1} \mathrm{H}$ NMR spectrum of 27.

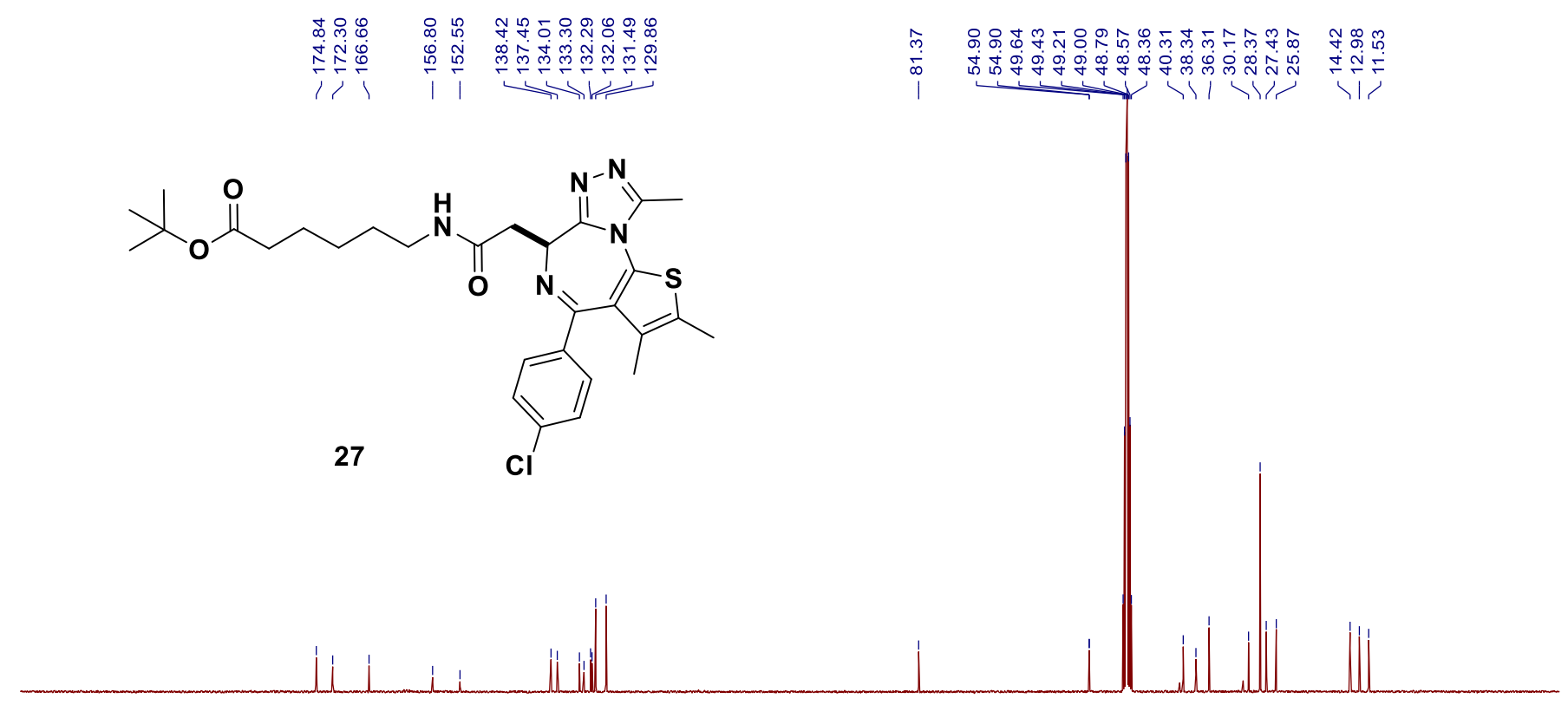

$\begin{array}{lllllllllllllllllllllllllll}1 & 20 & 210 & 200 & 190 & 180 & 170 & 160 & 150 & 140 & 130 & 120 & 110 & 100 & 90 & 80 & 70 & 60 & 50 & 40 & 30 & 20 & 10 & 0 & -10 & \end{array}$

Figure S46. ${ }^{13} \mathrm{C}$ NMR spectrum of 27. 


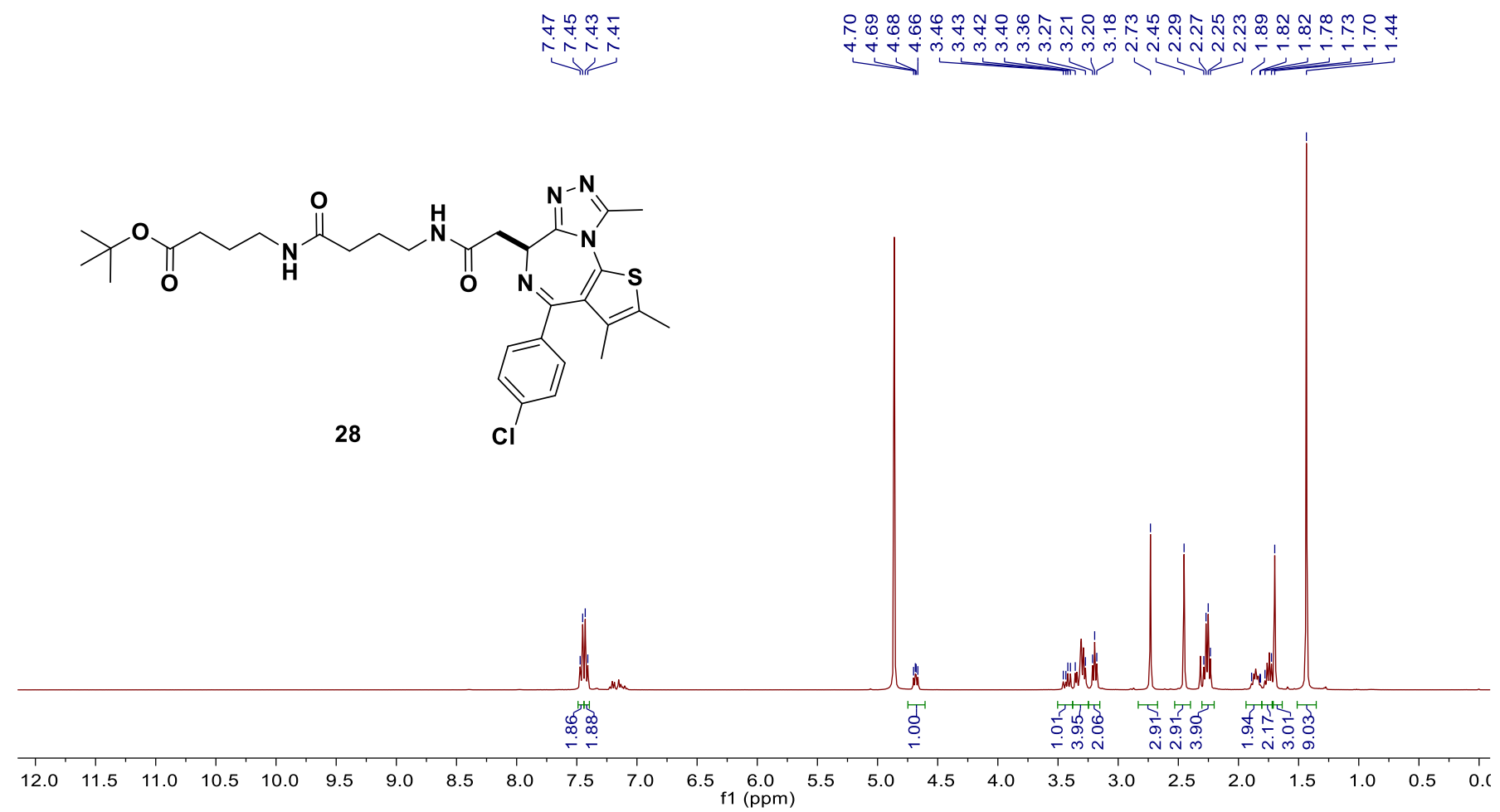

Figure S47. ${ }^{1} \mathrm{H}$ NMR spectrum of 28.
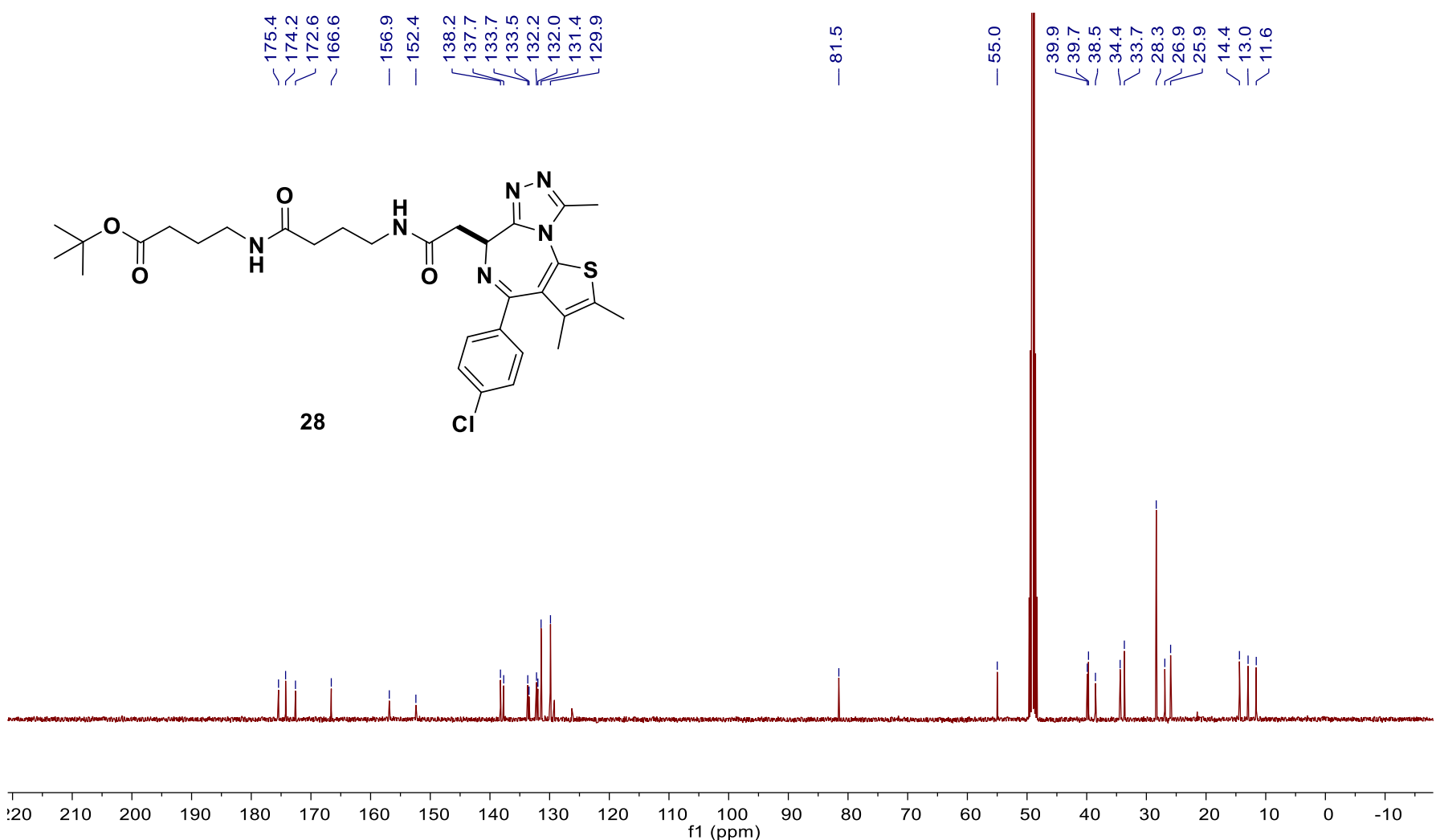

Figure S48. ${ }^{13} \mathrm{C}$ NMR spectrum of 28. 


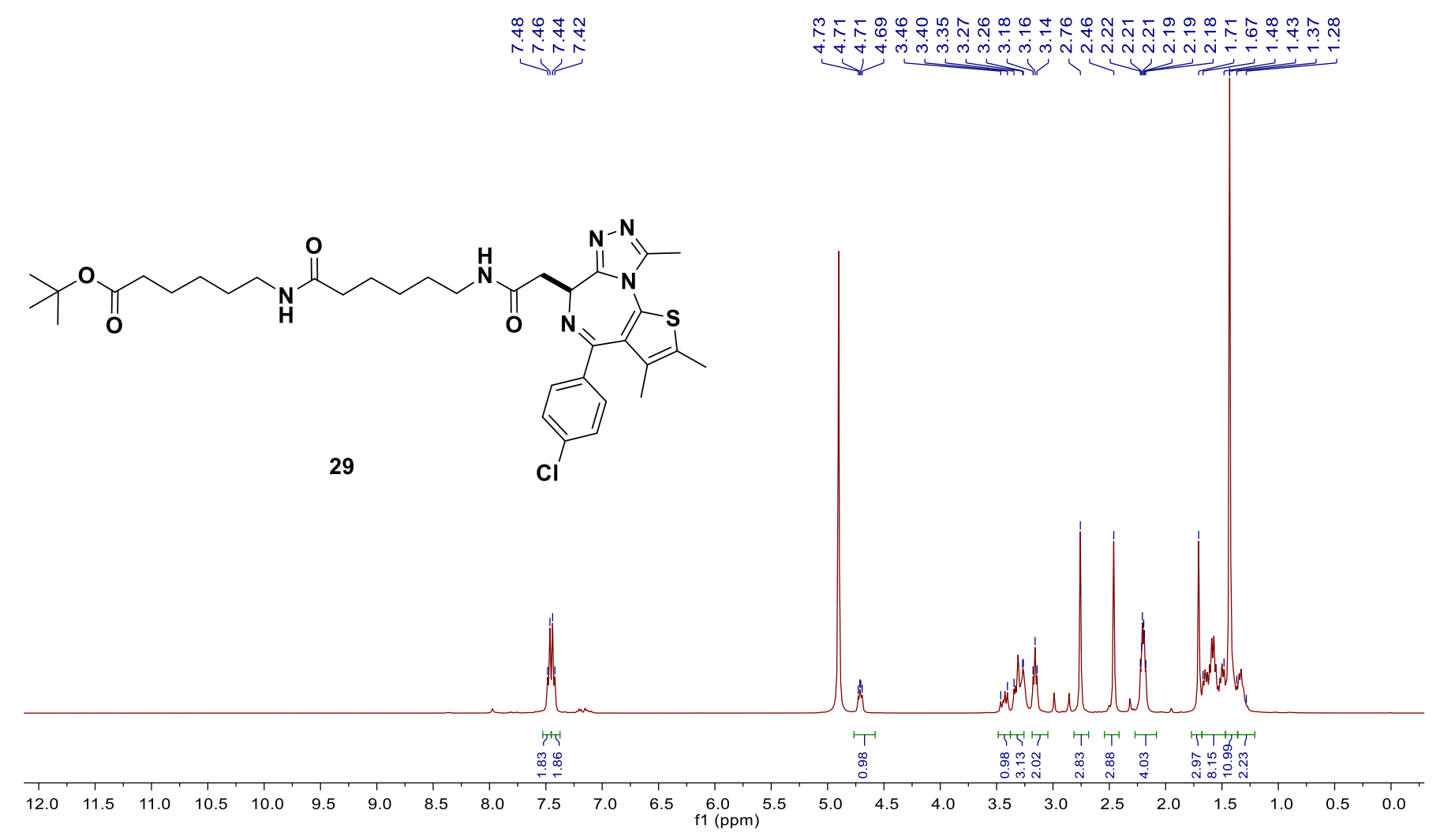

Figure S49. ${ }^{1} \mathrm{H}$ NMR spectrum of 29.

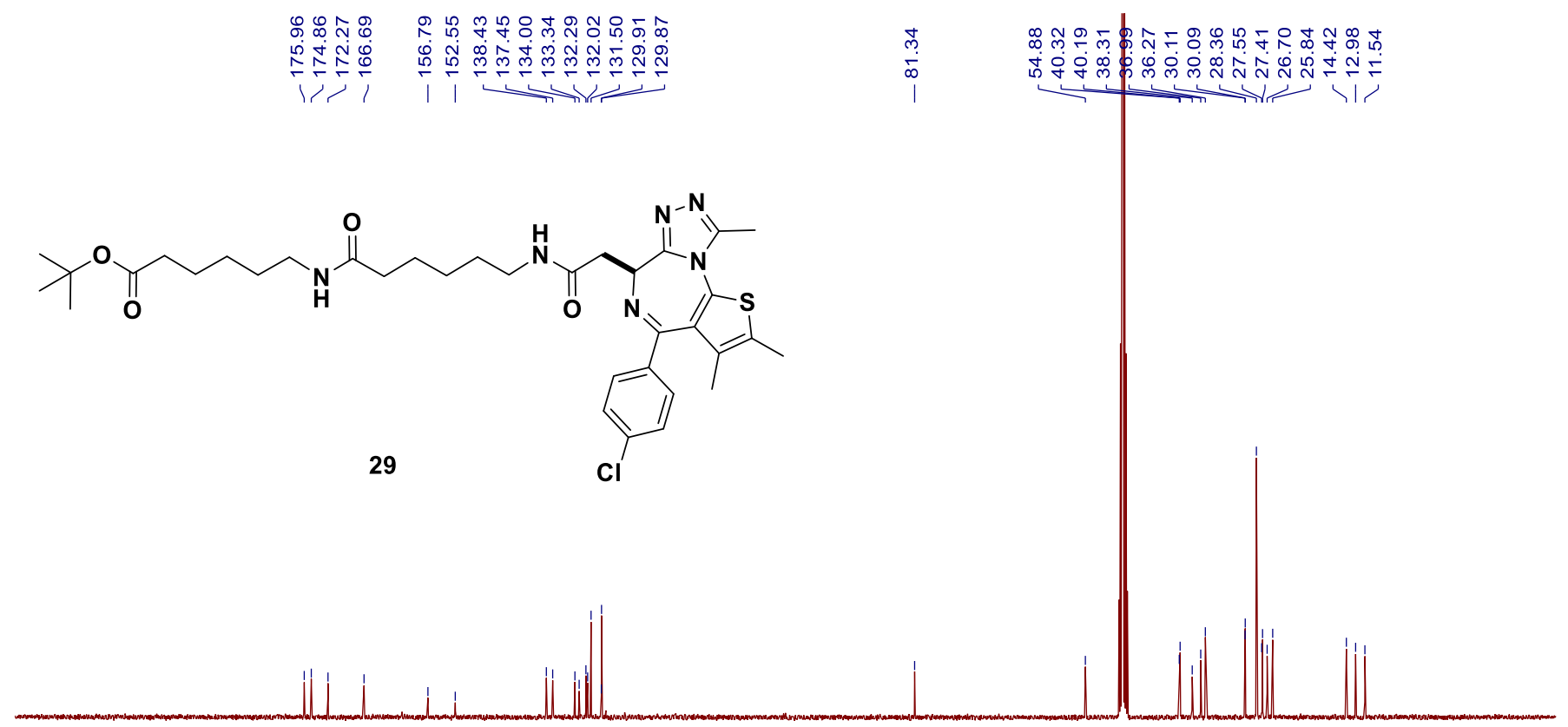

$\begin{array}{lllllllllllllllllllllllllllllll}1 & 20 & 210 & 200 & 190 & 180 & 170 & 160 & 150 & 140 & 130 & 120 & 110 & 100 & 90 & 80 & 70 & 60 & 50 & 40 & 30 & 20 & 10 & 0 & -10 & 10\end{array}$

Figure S50. ${ }^{13} \mathrm{C}$ NMR spectrum of 29. 


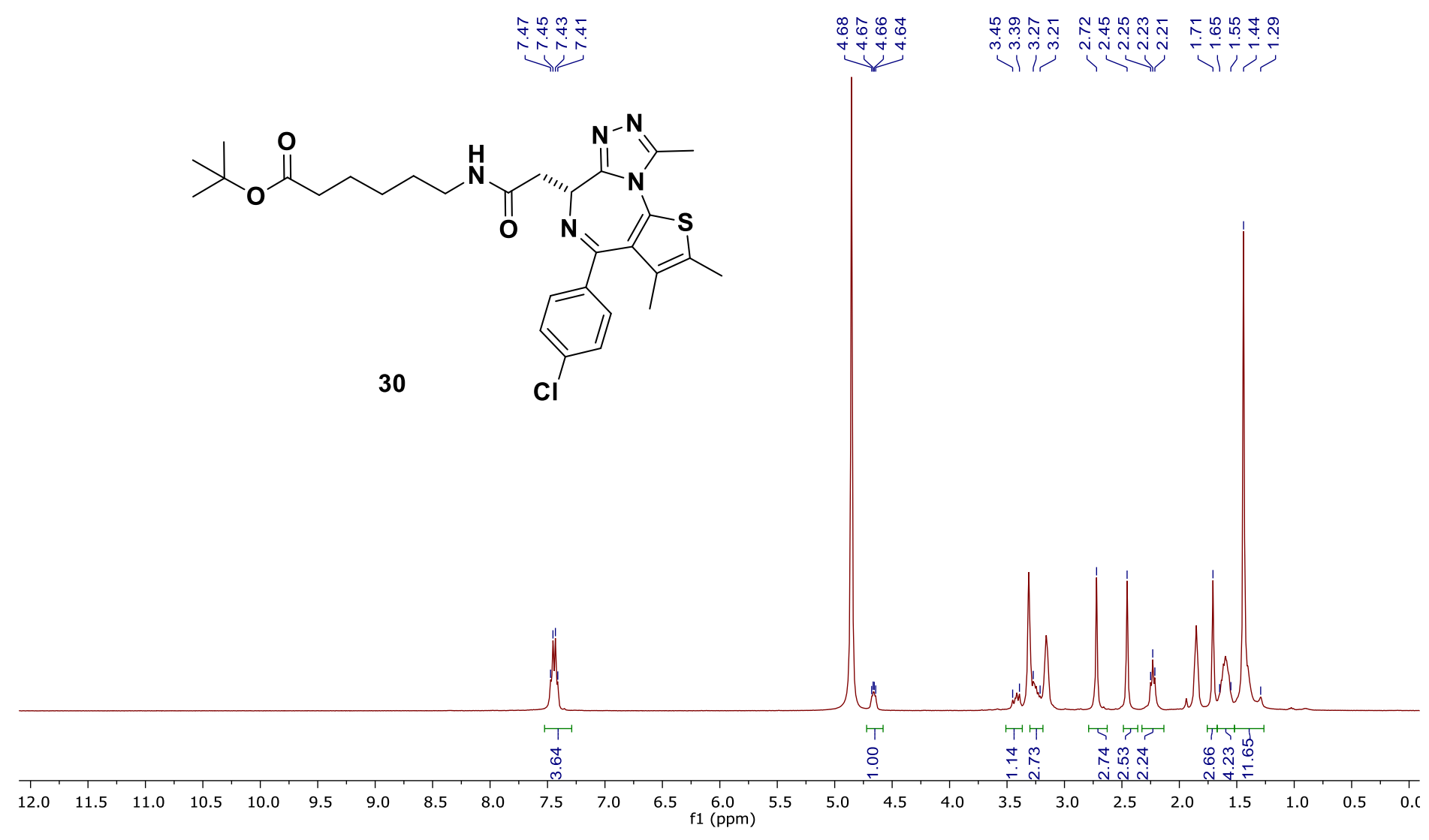

Figure S51. ${ }^{1} \mathrm{H}$ NMR spectrum of 30

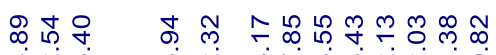

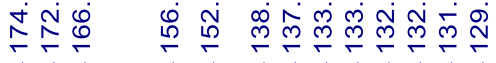

i i । ।
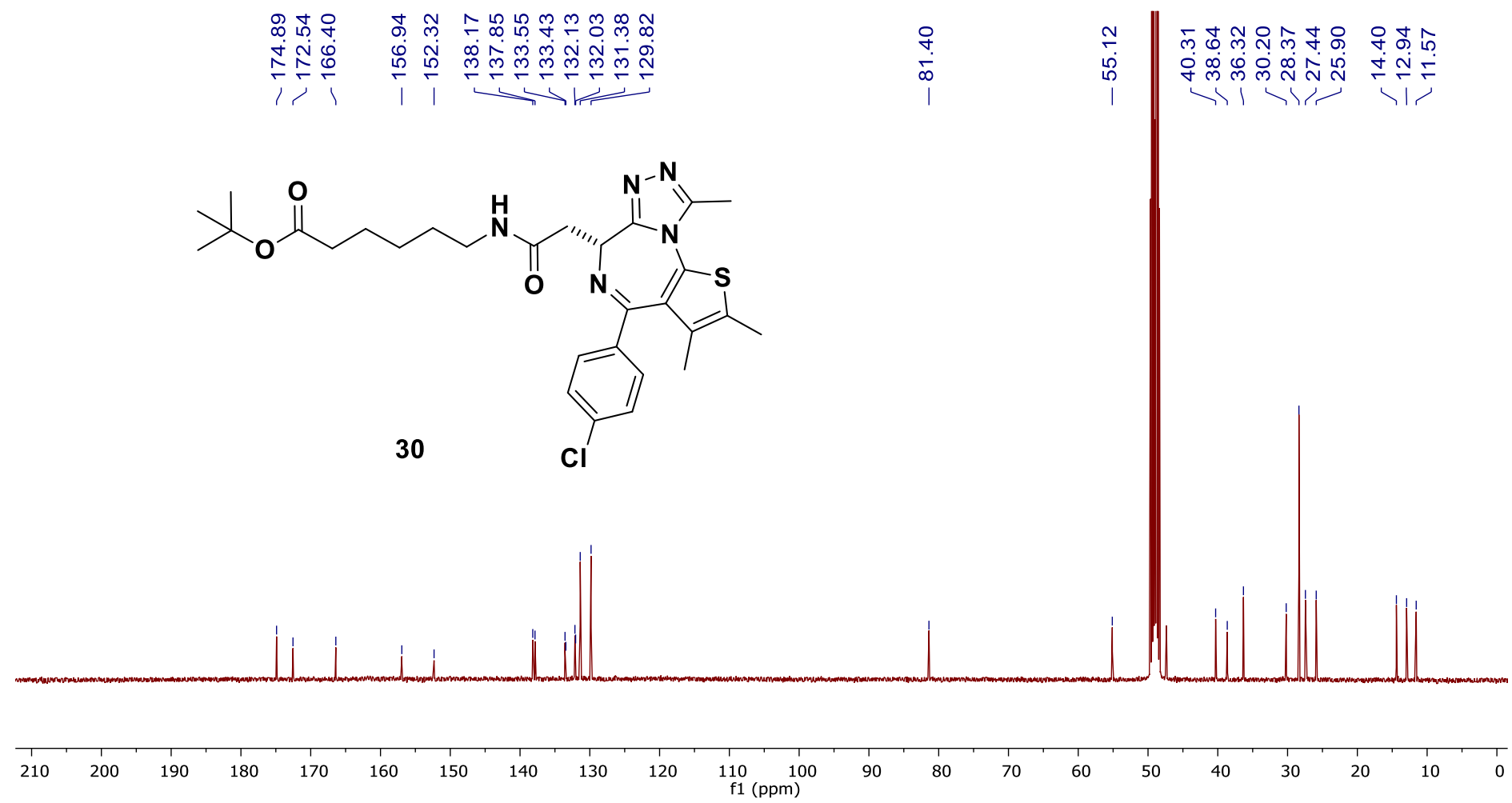

Figure S52. ${ }^{13} \mathrm{C}$ NMR spectrum of $\mathbf{3 0}$. 

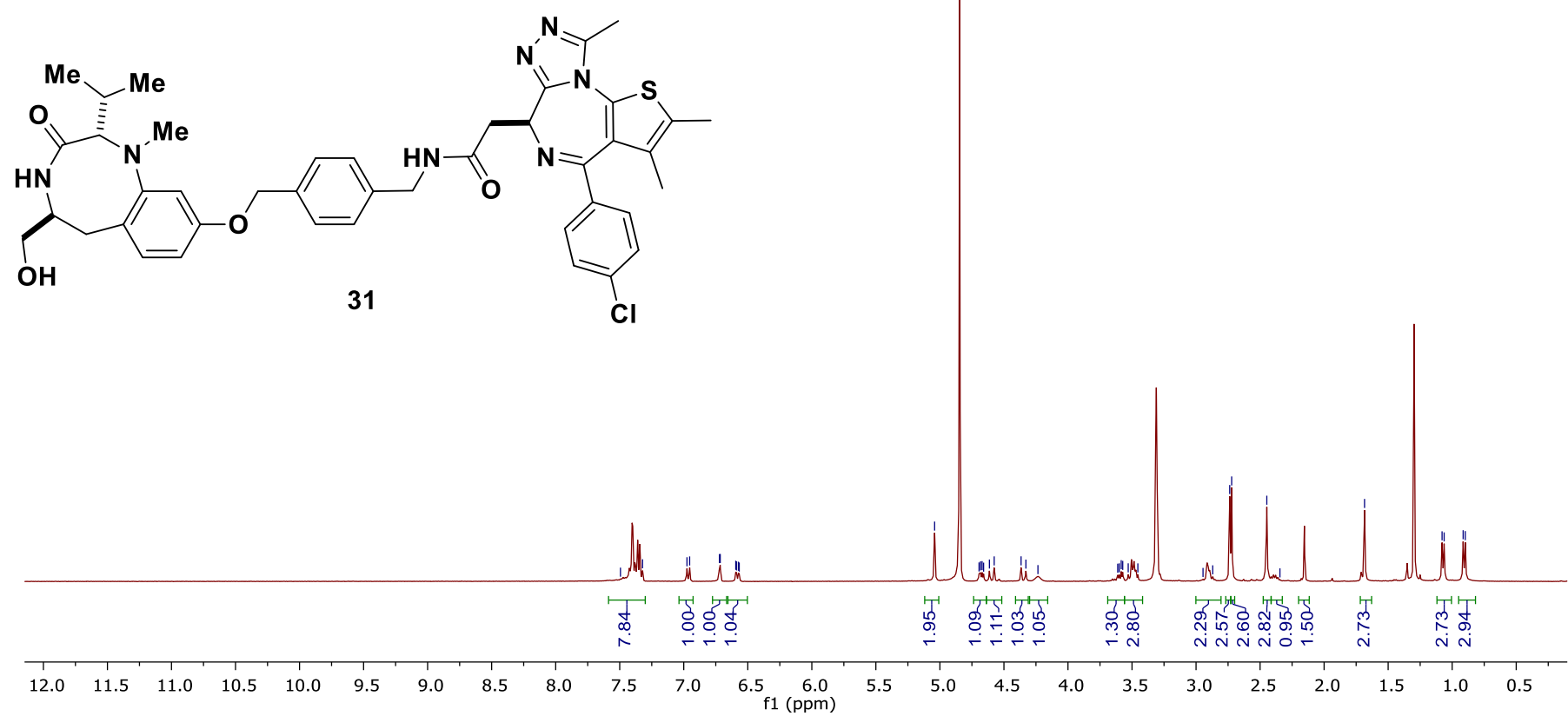

Figure S53. ${ }^{1} \mathrm{H}$ NMR spectrum of $\mathbf{3 1}$.
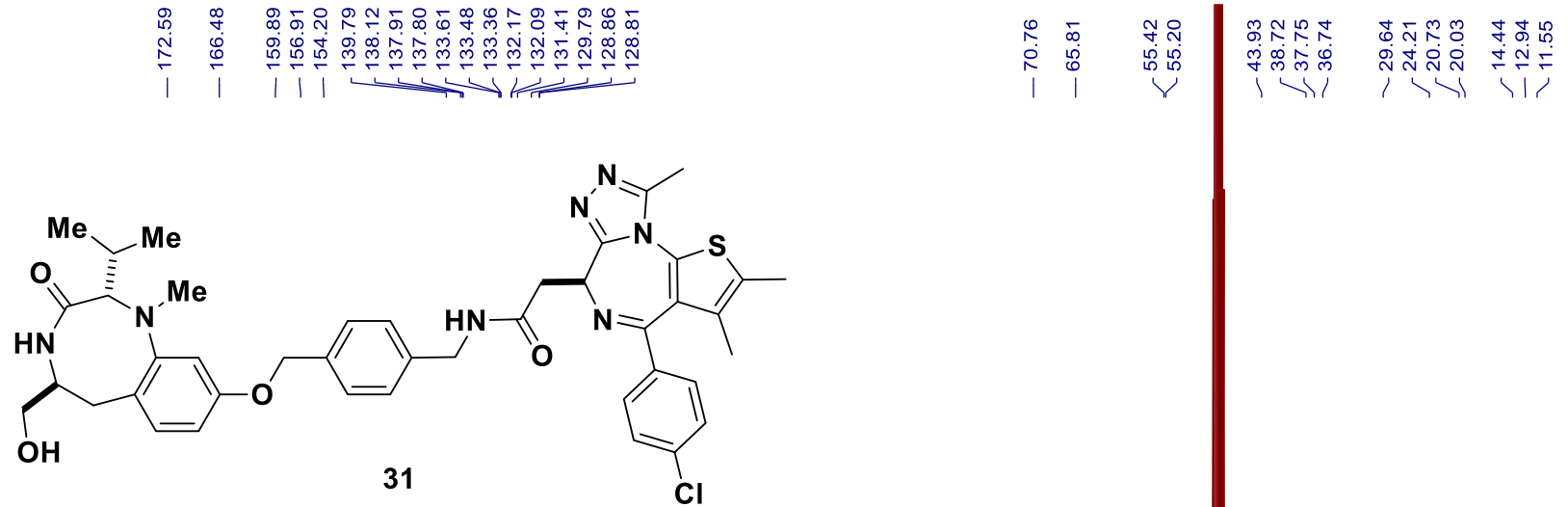

Figure S54. ${ }^{13} \mathrm{C}$ NMR spectrum of 31. 


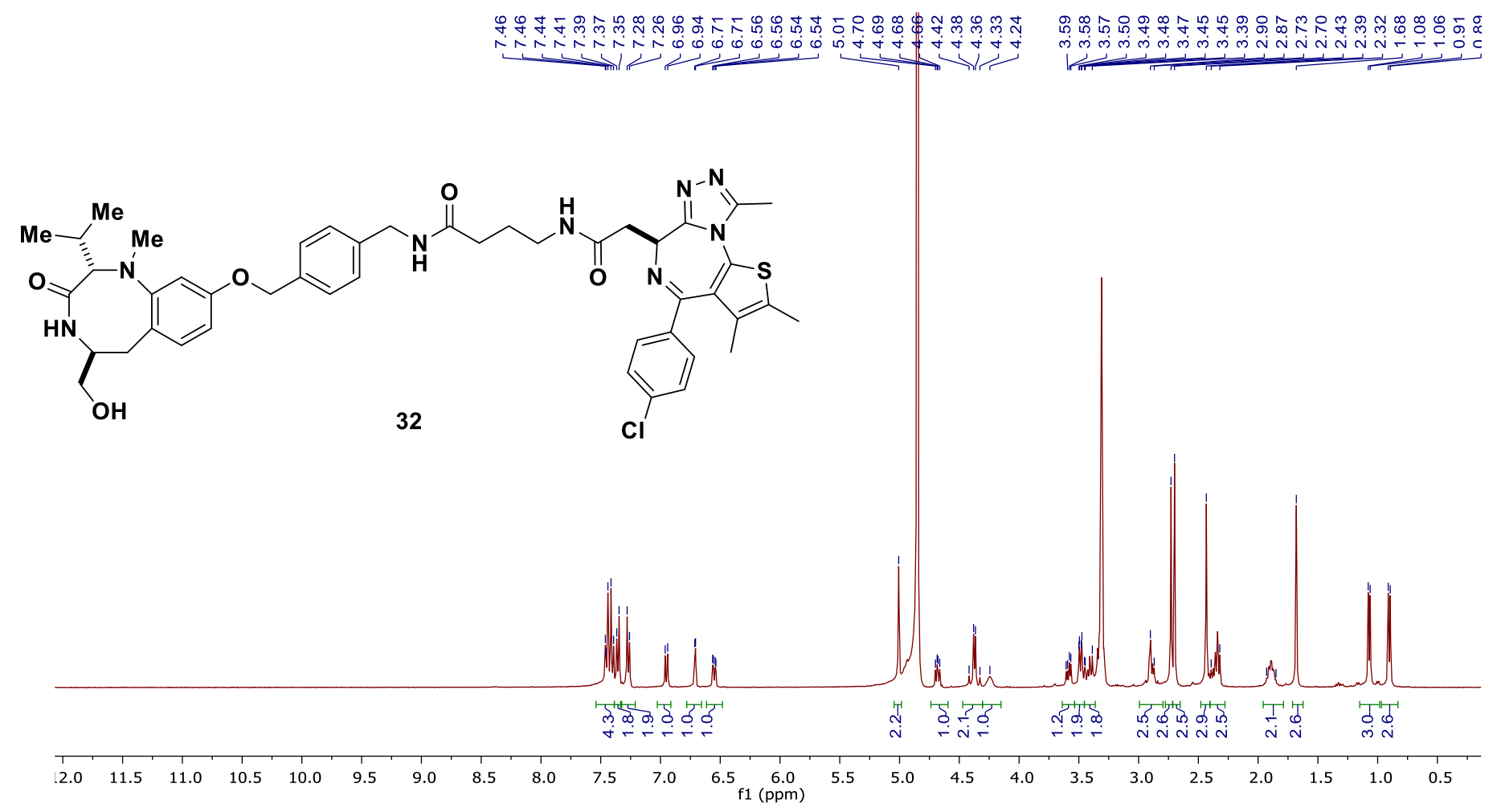

Figure S55. ${ }^{1} \mathrm{H}$ NMR spectrum of 32.
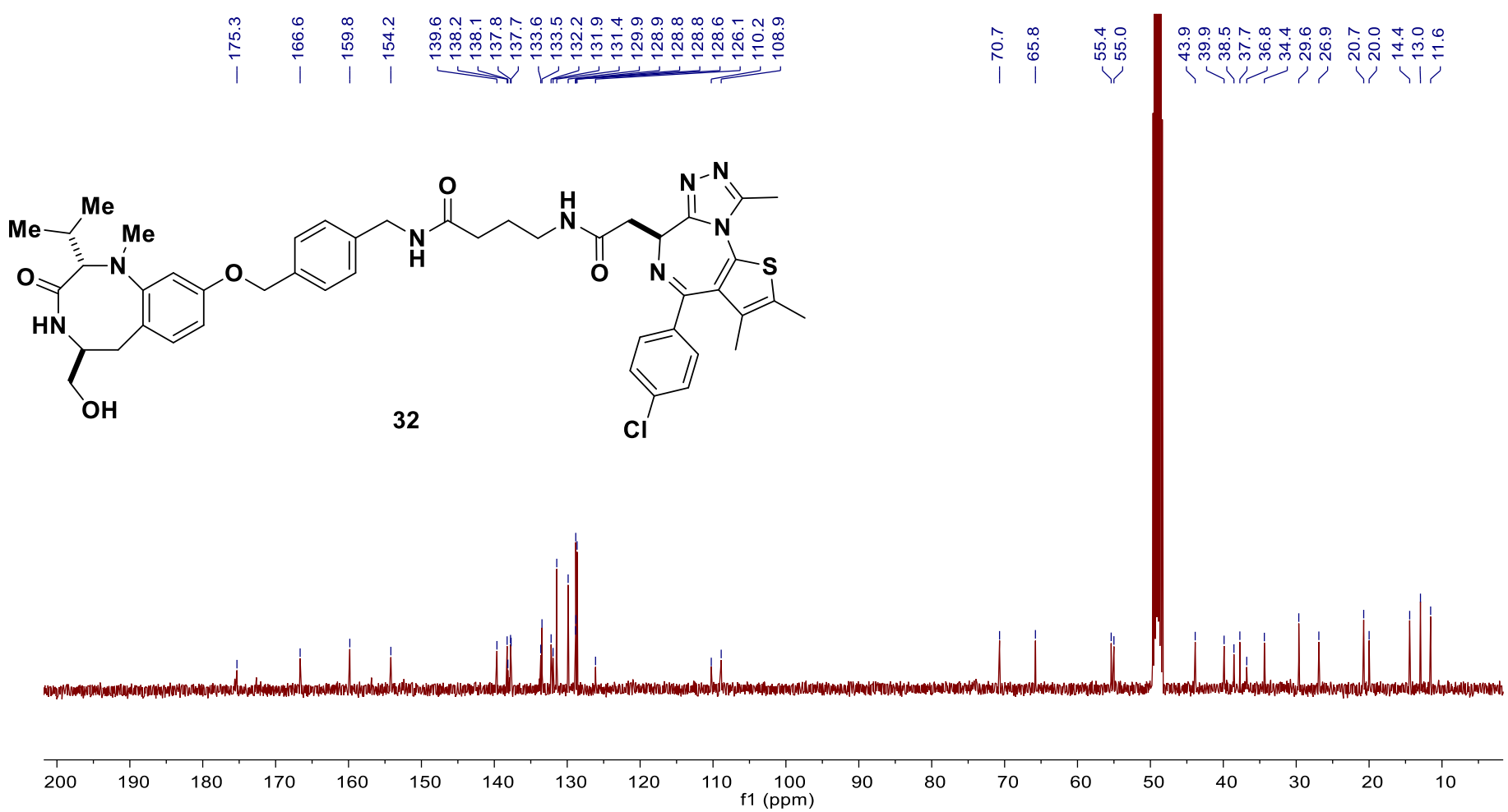

Figure S56. ${ }^{13} \mathrm{C}$ NMR spectrum of 32. 


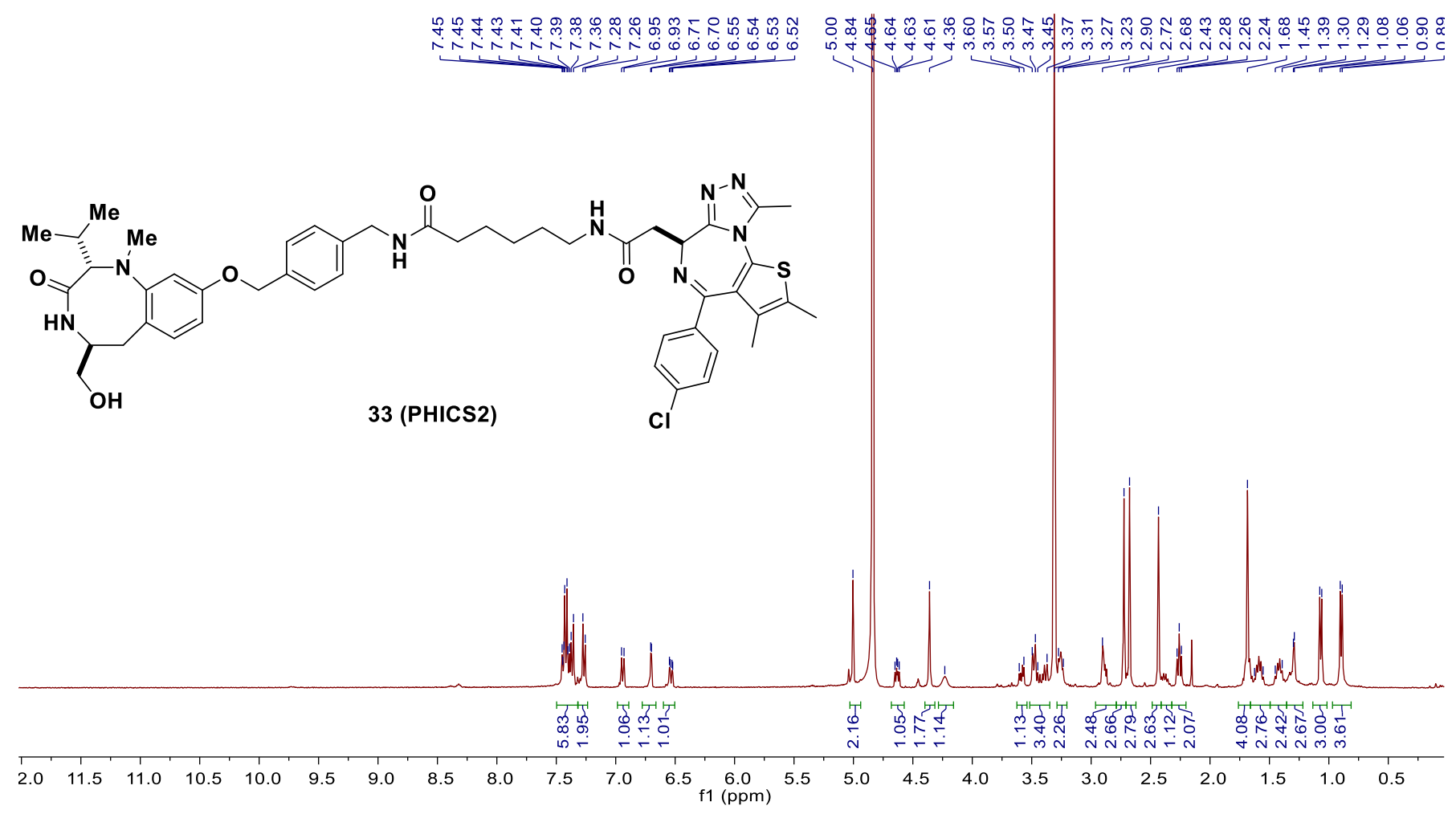

Figure S57. ${ }^{1} \mathrm{H}$ NMR spectrum of 33 (PHICS2).

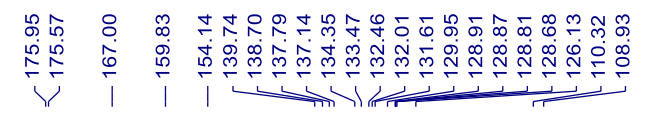

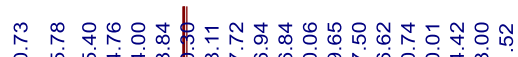

ค่

।<smiles>Cc1sc2c(c1C)C(c1ccc(Cl)cc1)=N[C@@H](CC(=O)NCCCCCC(=O)NCc1ccc(COc3ccc4c(c3)N(C)[C@@H](C(C)C)C(=O)N[C@H](CO)C4)cc1)c1nnc(C)n1-2</smiles>

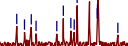

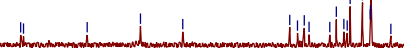

Figure S58. ${ }^{13} \mathrm{C}$ NMR spectrum of 33 (PHICS2). 


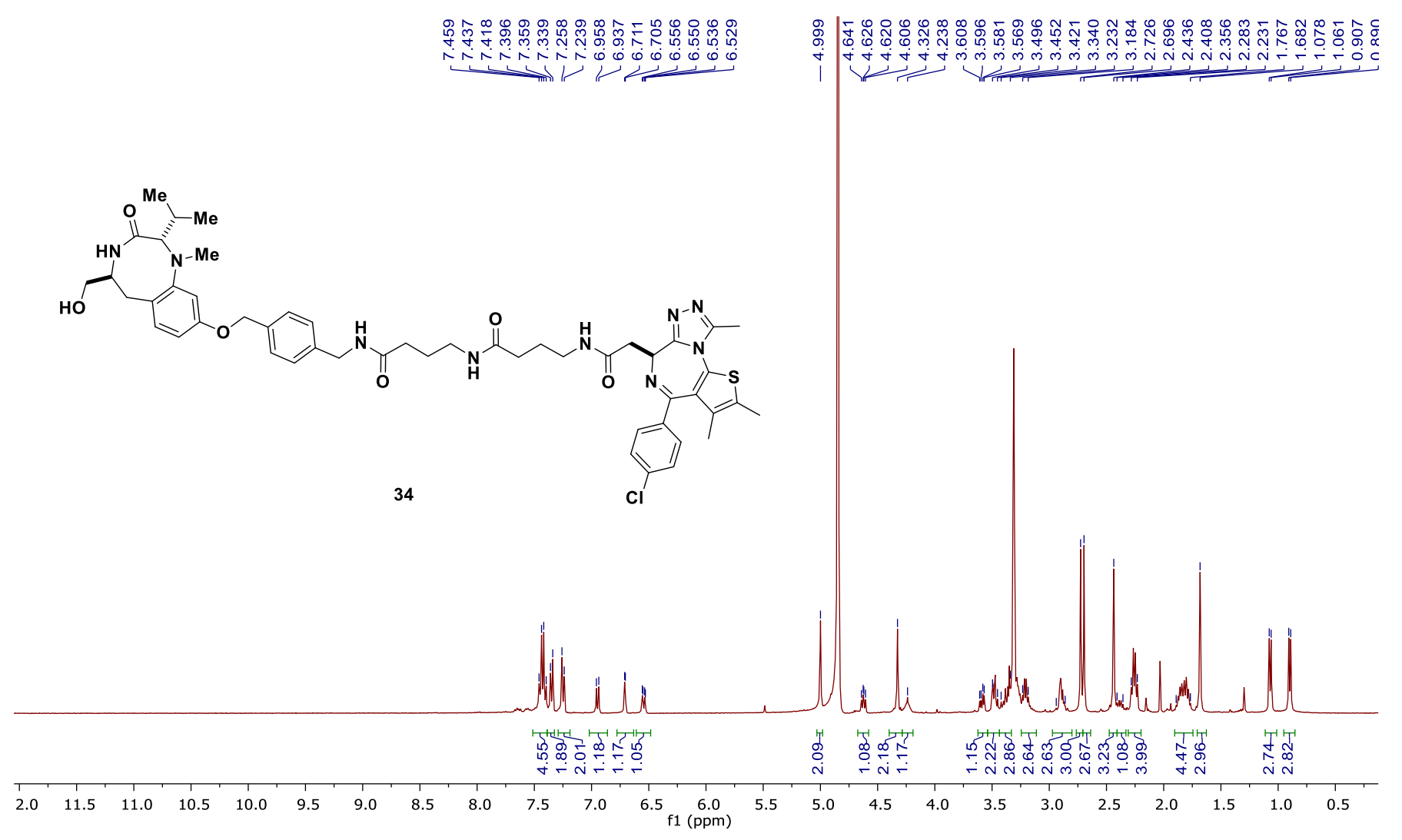

Figure S59. ${ }^{1} \mathrm{H}$ NMR spectrum of 34 .

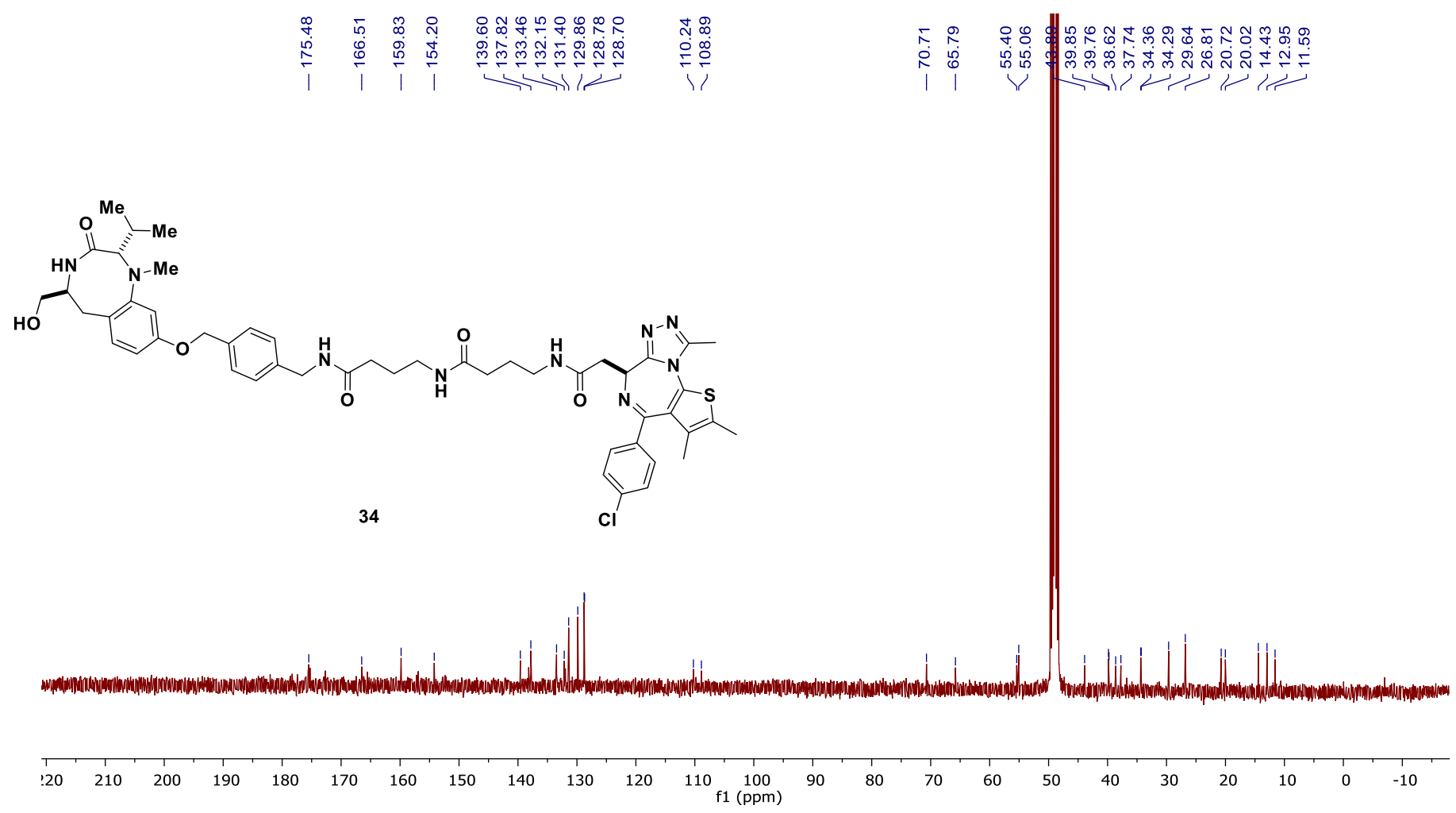

Figure S60. ${ }^{13} \mathrm{C}$ NMR spectrum of 34 . 


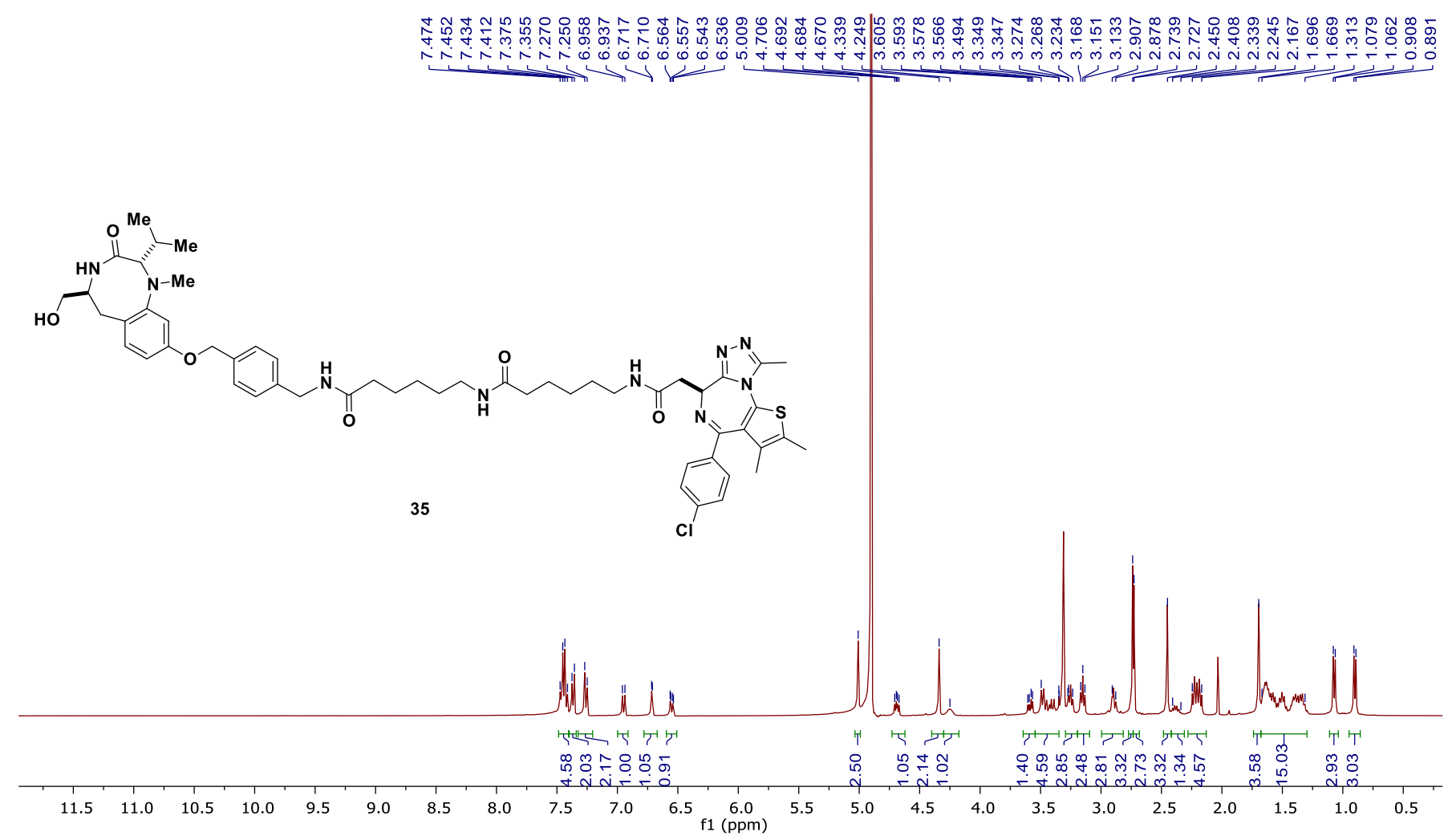

Figure S61. ${ }^{1} \mathrm{H}$ NMR spectrum of 35.

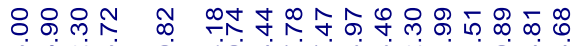

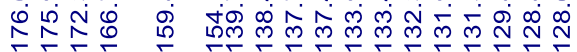

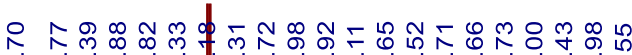

Fi,

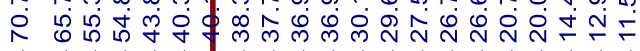<smiles>Cc1ccc2c(c1)N(C)[C@H](C(C)C)C(=O)N[C@H](CO)C2</smiles>

21
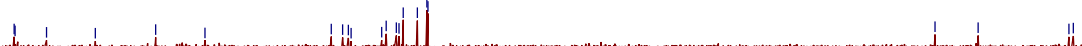

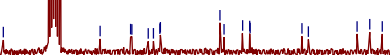

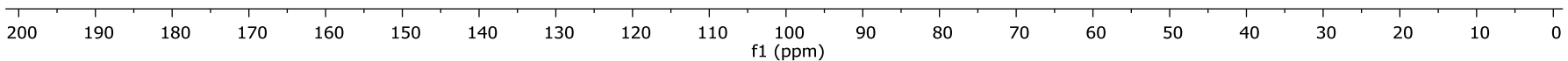

Figure S62. ${ }^{13} \mathrm{C}$ NMR spectrum of 35 . 


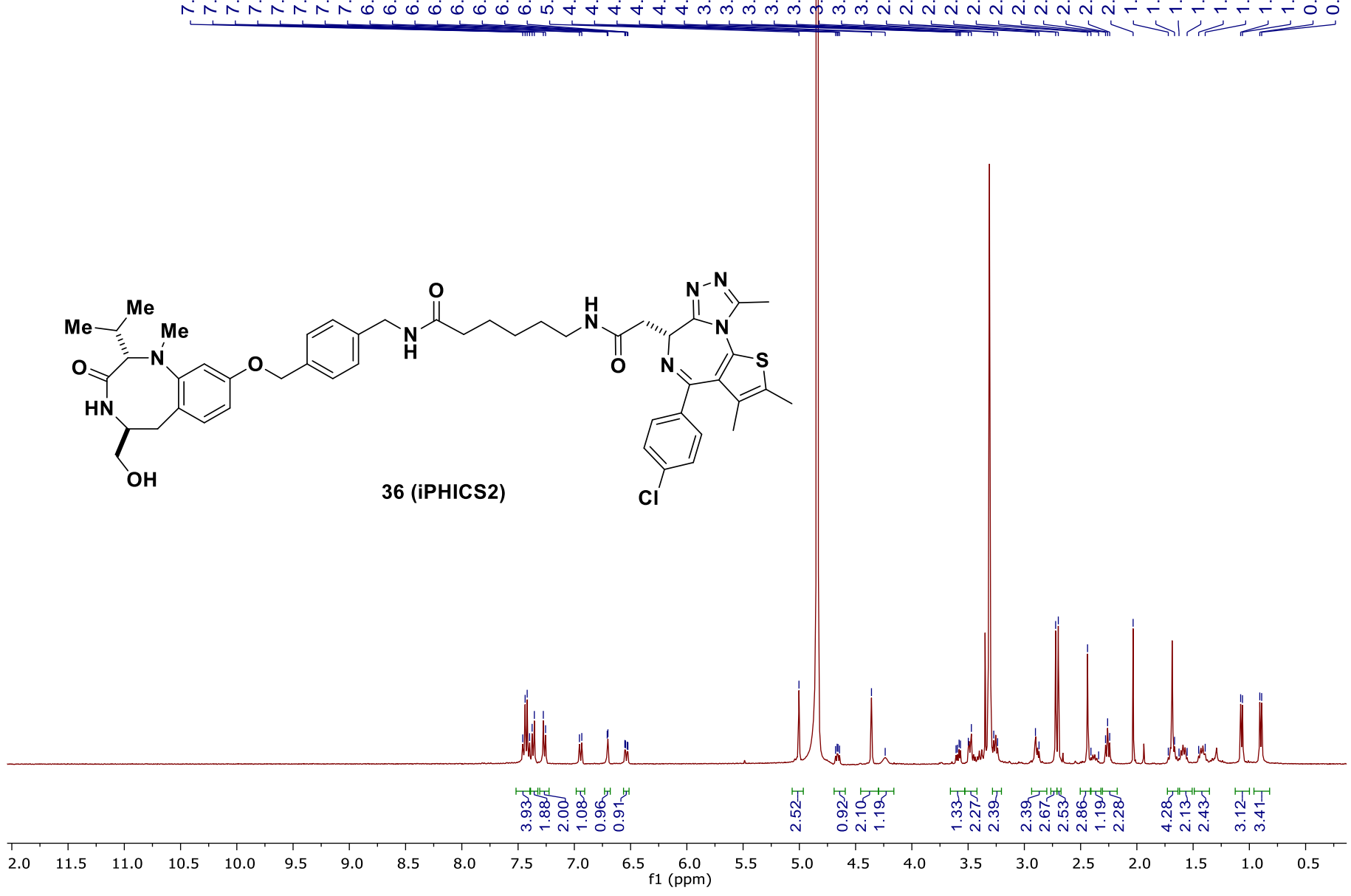

Figure S63. ${ }^{1} \mathrm{H}$ NMR spectrum of 36 (iPHICS2).<smiles>Cc1sc2c(c1C)C(c1ccc(Cl)cc1)=N[C@@H](CC(=O)NCCCCCC(=O)NCc1ccc(COc3ccc4c(c3)N(C)[C@@H](C(C)C)C(=O)N[C@@H](CO)C4)cc1)c1nnc(C)n1-2</smiles>

Figure S64. ${ }^{13} \mathrm{C}$ NMR spectrum of 36 (iPHICS2). 
<smiles>Nc1ncnc2c1c(-c1ccc(Oc3ccccc3)cc1)nn2[C@H]1CCCN(C(=O)CCCCCCCCC(=O)ON2C(=O)CCC2=O)C1</smiles>

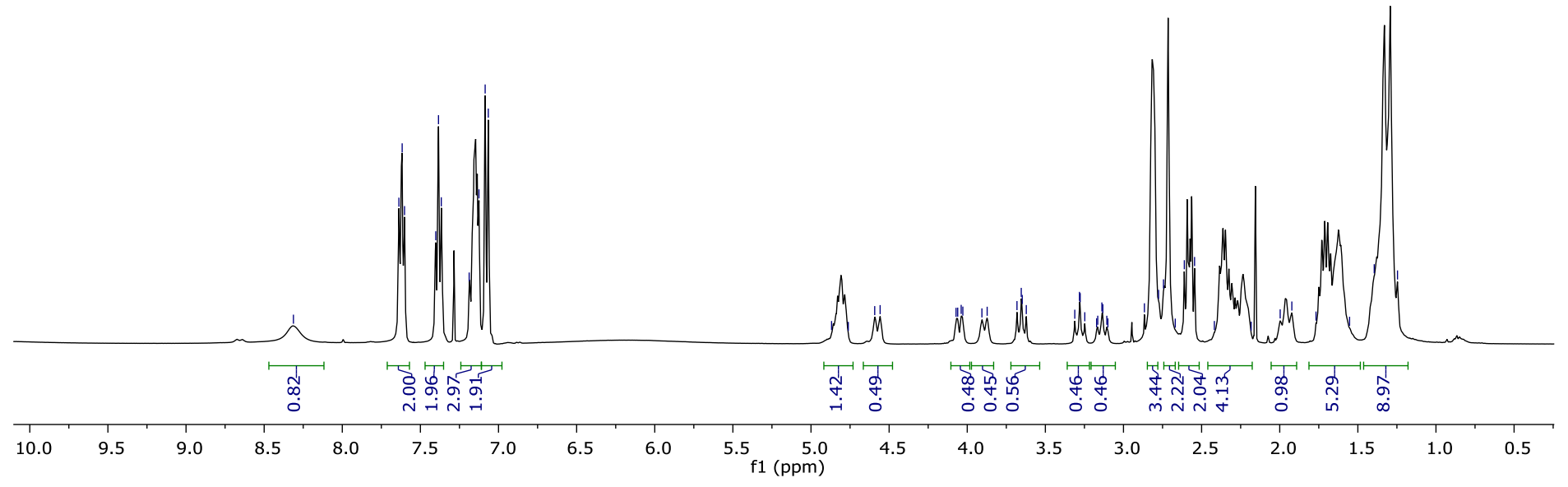

Figure S65. ${ }^{1} \mathrm{H}$ NMR spectrum of 37.

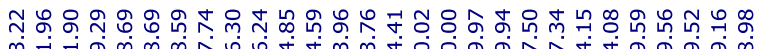

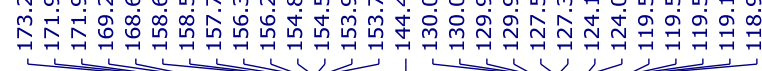<smiles>Nc1ncnc2c1c(-c1ccc(Oc3ccccc3)cc1)nn2[C@H]1CCCN(C(=O)CCCCCCCCC(=O)ON2C(=O)CCC2=O)C1</smiles>
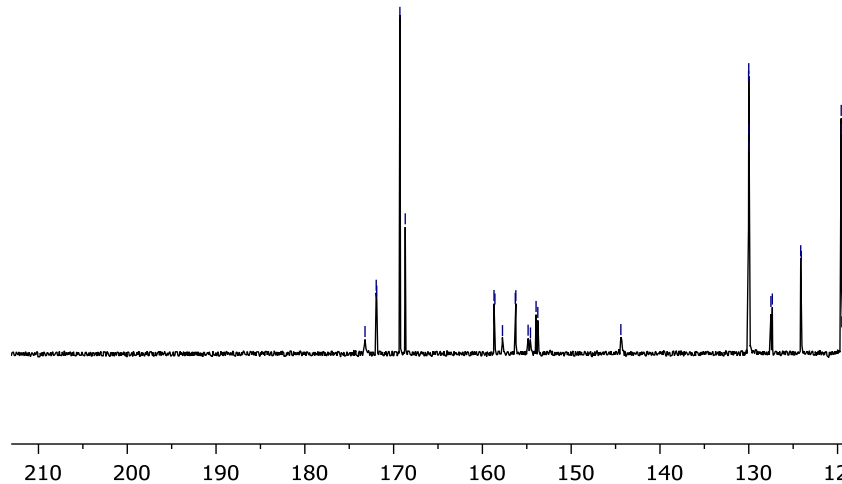

130

120

110 f1 (ppm)

Figure S66. ${ }^{13} \mathrm{C}$ NMR spectrum of 37. 


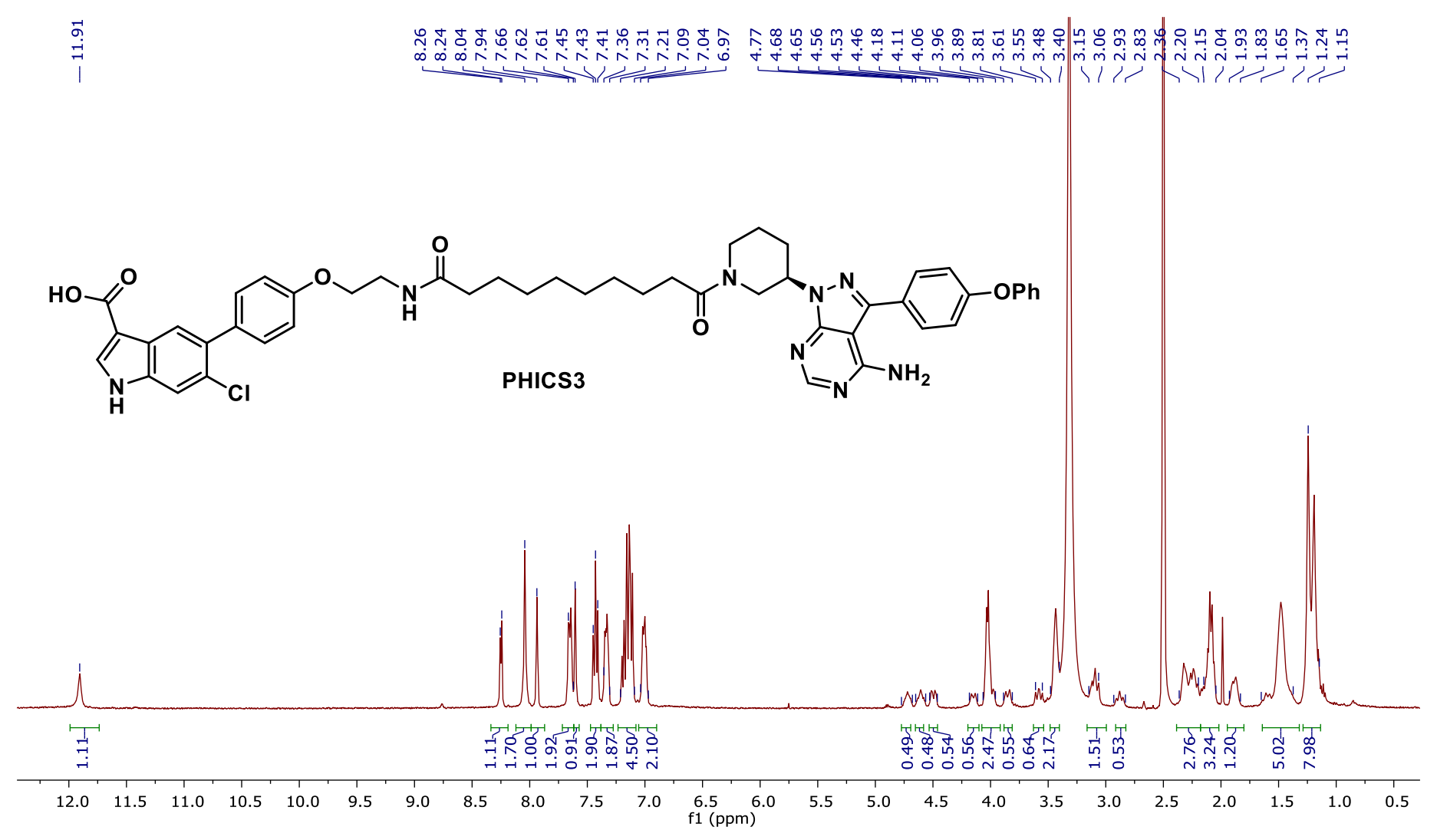

Figure S67. ${ }^{1} \mathrm{H}$ NMR spectrum of PHICS3 recorded in DMSO-d6.

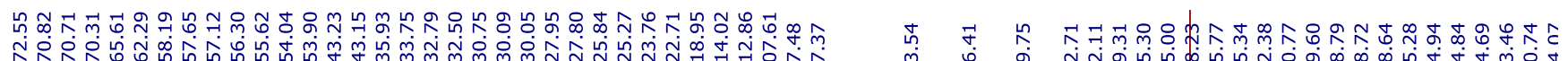

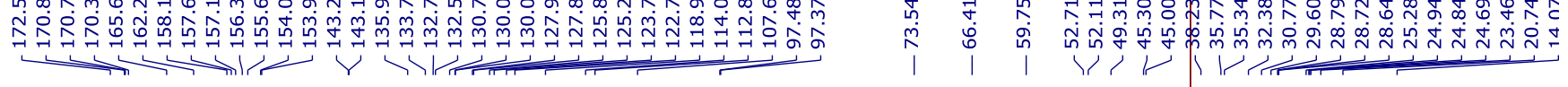<smiles>Nc1ncnc2c1c(-c1ccc(Oc3ccccc3)cc1)nn2C1CCCN(C(=O)CCCCCCCCC(=O)NCCOc2ccc(-c3cc4c(C(=O)O)c[nH]c4cc3Cl)cc2)C1</smiles>

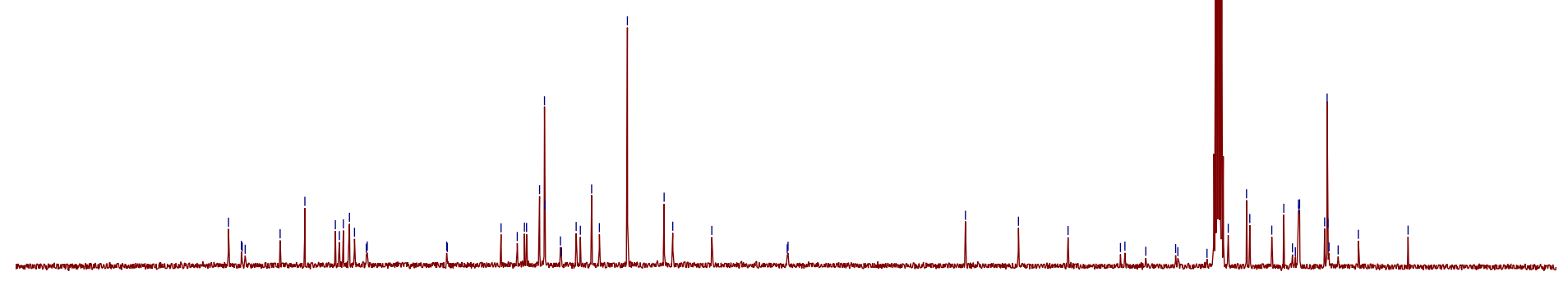

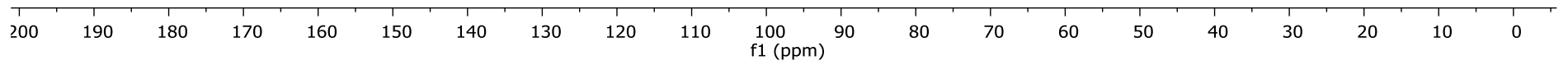

Figure S68. ${ }^{1} \mathrm{H}$ NMR spectrum of PHICS3 recorded in DMSO-d6. 


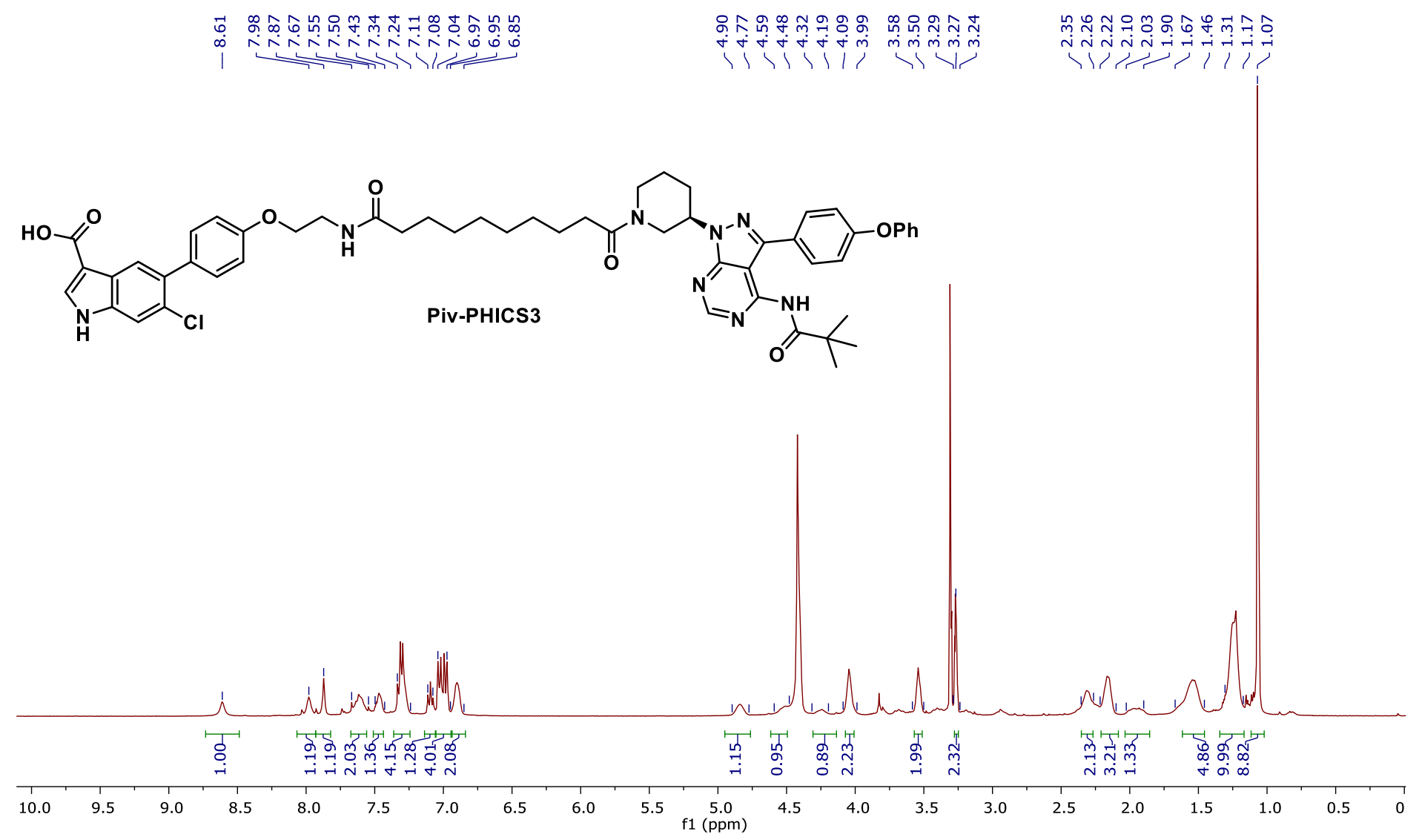

Figure S69. ${ }^{1} \mathrm{H}$ NMR spectrum of Piv-PHICS3 recorded in $\mathrm{CDCl}_{3}: \mathrm{CD}_{3} \mathrm{OD}(1: 1)$ solvent mixture.

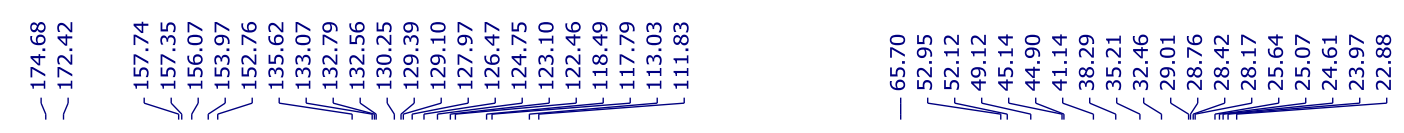<smiles>CC(C)(C)C(=O)Nc1ncnc2c(-c3ccc(Oc4ccccc4)cc3)nn([C@H]3CCCN(C(=O)CCCCCCCCC(=O)NCCOc4ccc(-c5cc6c(C(=O)O)c[nH]c6cc5Cl)cc4)C3)c12</smiles>

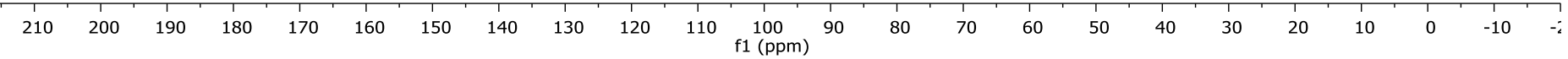

Figure S70. ${ }^{13} \mathrm{C}$ NMR spectrum of Piv-PHICS3 recorded in $\mathrm{CDCl}_{3}: \mathrm{CD}_{3} \mathrm{OD}(1: 1)$ solvent mixture. 


\section{References}

1. Zegzouti, H.; Zdanovskaia, M.; Hsiao, K.; Goueli, S. A., ADP-Glo: A Bioluminescent and homogeneous ADP monitoring assay for kinases. Assay and drug development technologies 2009, 7 (6), 560-72.

2. Bielefeld-Sevigny, M., AlphaLISA immunoassay platform- the "no-wash" high-throughput alternative to ELISA. Assay Drug Dev. Technol. 2009, 7 (1), 90-2.

3. Wu, S. Y.; Lee, A. Y.; Lai, H. T.; Zhang, H.; Chiang, C. M., Phospho switch triggers Brd4 chromatin binding and activator recruitment for gene-specific targeting. Molecular cell 2013, 49 (5), 843-57.

4. Tyler, D. S.; Vappiani, J.; Caneque, T.; Lam, E. Y. N.; Ward, A.; Gilan, O.; Chan, Y. C.; Hienzsch, A.; Rutkowska, A.; Werner, T.; Wagner, A. J.; Lugo, D.; Gregory, R.; Ramirez Molina, C.; Garton, N.; Wellaway, C. R.; Jackson, S.; MacPherson, L.; Figueiredo, M.; Stolzenburg, S.; Bell, C. C.; House, C.; Dawson, S. J.; Hawkins, E. D.; Drewes, G.; Prinjha, R. K.; Rodriguez, R.; Grandi, P.; Dawson, M. A., Click chemistry enables preclinical evaluation of targeted epigenetic therapies. Science 2017, 356 (6345), 13971401.

5. Su, Y. C.; Lo, Y. L.; Hwang, C. C.; Wang, L. F.; Wu, M. H.; Wang, E. C.; Wang, Y. M.; Wang, T. P., Azidealkyne cycloaddition for universal post-synthetic modifications of nucleic acids and effective synthesis of bioactive nucleic acid conjugates. Organic \& biomolecular chemistry 2014, 12 (34), 6624-33.

6. Cameron, K. O.; Kung, D. W.; Kalgutkar, A. S.; Kurumbail, R. G.; Miller, R.; Salatto, C. T.; Ward, J.; Withka, J. M.; Bhattacharya, S. K.; Boehm, M.; Borzilleri, K. A.; Brown, J. A.; Calabrese, M.; Caspers, N. L.; Cokorinos, E.; Conn, E. L.; Dowling, M. S.; Edmonds, D. J.; Eng, H.; Fernando, D. P.; Frisbie, R.; Hepworth, D.; Landro, J.; Mao, Y.; Rajamohan, F.; Reyes, A. R.; Rose, C. R.; Ryder, T.; Shavnya, A.; Smith, A. C.; Tu, M.; Wolford, A. C.; Xiao, J., Discovery and Preclinical Characterization of 6-Chloro-5-[4(1-hydroxycyclobutyl)phenyl]-1H-indole-3-carboxylic Acid (PF-06409577), a Direct Activator of Adenosine Monophosphate-activated Protein Kinase (AMPK), for the Potential Treatment of Diabetic Nephropathy. Journal of medicinal chemistry 2016, 59 (17), 8068-81.

7. Ma, D.; Tang, W.; Kozikowski, A. P.; Lewin, N. E.; Blumberg, P. M., General and Stereospecific Route to 9Substituted, 8,9-Disubstituted, and 9,10-Disubstituted Analogues of Benzolactam-V8. J. Org. Chem. 1999, 64 (17), 6366-6373.

8. Divakaran, A.; Talluri, S. K.; Ayoub, A. M.; Mishra, N. K.; Cui, H.; Widen, J. C.; Berndt, N.; Zhu, J.-Y.; Carlson, A. S.; Topczewski, J. J.; Schonbrunn, E. K.; Harki, D. A.; Pomerantz, W. C. K., Molecular Basis for the N-Terminal Bromodomain-and-Extra-Terminal-Family Selectivity of a Dual Kinase-Bromodomain Inhibitor. J. Med. Chem. 2018, 61 (20), 9316-9334. 